Universidad Nacional de La Plata

Facultad de Humanidades y Ciencias de la Educación

Doctorado en Letras

\title{
Fronteras de la teatralidad en la obra de Copi: identidades, cuerpos, géneros
}

\author{
Tesis doctoral en Letras
}

Doctorando: Prof. Ignacio LUCIA

Director de tesis: Prof. Dr José Amícola

Año de entrega de la tesis: 2020 


\section{ÍNDICE}

Agradecimientos.................................................................4

0.0. Introducción...............................................................

0.1. ¿De dónde viene Copi? ...........................................................

0.2. Identidades de sexo-género................................9

0.2.1. Identidad, cuerpo, género. Una intersección problemática............................................................12

0.3. Teatro y teatralidad.........................................14

0.4. Subjetividades "en exilio", subjetividades trans.........18

0.5. Preguntas e Hipótesis........................................20

0.6. Estado de la cuestión......................................21

0.7. Organización de la tesis...................................30

Capítulo 1: Sujetos “no-hegemónicos”...................................34

1.1. El sujeto y su caída.............................................34

1.2. Cuerpos abyectos..........................................41

Capítulo 2: El “mundillo” y el “mundo”....................................48

2.1. Un cerco de injurias.........................................48

2.2. Formas de salida...........................................53

Capítulo 3: Sujetos en tránsito..........................................65

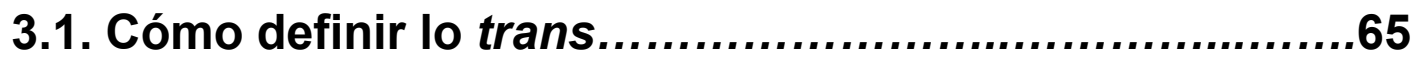

3.2. Transexualidad y travestismo.............................66

3.3. Transgenerismo.............................................68

Capítulo 4: Cuerpos en escena.........................................75

4.1. El travestismo como recurso teatral.......................75

4.2. El travestismo y la performance/performatividad.........83

4.2.1. La performatividad como vehículo de lo queer........89 
4.2.2. El travestismo como subversión: teatro

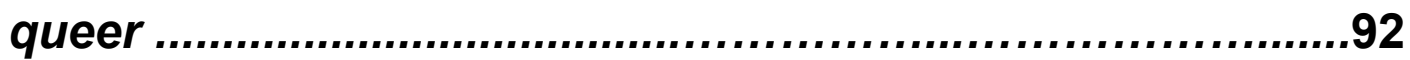

Capítulo 5: El teatro y la "acción" .........................................98

5.1. Anti-happening ..........................................98

5.2. La marioneta viviente.......................................108

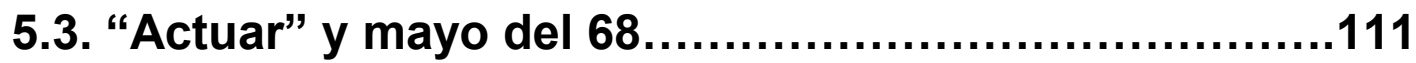

Capítulo 6: Jean Genet y los vestidos de Eva............................116

6.1. Una cuestión de tissus....................................116

6.2. Sobre-vivir...............................................125

6.3. Un teatro post-genetiano...............................................126

Capítulo 7: Espacios escénicos y espacios subjetivos.................131

7.1. Encierro mental.............................................131

7.2. Uni-personal, des-personal...........................142

Capítulo 8: Más allá del teatro..............................................153

Capítulo 9: Los hombres de la literatura argentina......................165

9.1. Sobre los roles...........................................165

9.2. Un tango bailado al revés.................................168

9.3. Gauchos sin territorio..................................178

9.4. Nación kitsch............................................183

Capítulo 10: Conclusiones.................................................................192

Bibliografía.......................................................................201 


\section{Agradecimientos}

Agradeco en primer lugar al Director de este trabajo, José Amícola, por su confianza desde el primer momento en el proyecto, sus lecturas esmeradas y detallistas del mismo, así como la orientación y la motivación constantes e incondicionales para llevarlo a cabo.

Al Departamento de Letras de la Facultad de Humanidades y Ciencias de la Educación (FaHCE) de la ciudad de La Plata, por su permanente cercanía con las investigaciones de posgrado.

A la directora actual del Doctorado en Letras de la Universidad Nacional de La Plata, Carolina Sancholuz, y al director anterior Miguel Dalmaroni, por su presencia y su orientación, así como al Comité Asesor.

Al Centro de Estudios de Teoría y Crítica Literaria (CTCL), y a su vez al Instituto de Investigación en Humanidades y en Ciencias Sociales (IdIHCS), y a sus directores, por permitirme radicar el proyecto en sus centros.

Al Consejo Nacional de Investigaciones Científicas y Técnicas (CONICET) por la beca doctoral (2012-2017) que me permitió llevar a cabo el trabajo de investigación necesario para esta tesis, pero también a la Universidad Nacional de La Plata (UNLP), por la Beca de Iniciación a la Investigación (2009-2011), y la Beca de Perfeccionamiento (2011-2012), dentro de las cuales, si bien trabajé sobre temas diferentes del de esta tesis, constituyeron un estímulo invaluable a la hora de decidirme a emprender el camino del Doctorado en Letras.

A los colegas que me han ayudado con el material de trabajo, así como también las opiniones e intercambios realizadas a lo largo de los años: Eduardo Muslip, Christian Estrade, Pablo Gasparini.

A mi familia (padres, hermano), por su presencia y ayuda incondicionales, y también a mis amigos/amigas de la Facultad. $Y$ a Constanza, por su acompañamiento, su apoyo y sus consejos valiosos. 


\subsection{Introducción}

\section{1. ¿De dónde viene Copi?}

Muchos de los textos críticos que en alguna ocasión se han referido a la obra de Copi no han podido evitar preguntarse acerca de su pertenencia a alguna "literatura nacional". ¿Era un autor argentino o francés? Por un lado, nació en Argentina, y su lengua materna era el español, o más precisamente la variante lingüística argentina. Pero, por otro lado, Copi abandonó esa lengua materna para pasar a escribir casi la totalidad de sus obras en francés, a partir de su instalación definitiva en Francia en 1962. Aun así, aunque la acción de muchas de sus obras ocurre en Francia, y son franceses sus personajes, también podemos ver aparecer personajes y tramas argentinas en otras de sus obras.

Cuando se habla del paso de Copi desde el castellano al francés, se lo suele oponer a otro argentino que efectúa ese pasaje, Héctor Bianciotti; se los diferencia en que, mientras Bianciotti habría llegado a una asimilación en la cultura adoptiva ${ }^{1}$, cuyo corolario sería la obtención de un puesto en la Academia Francesa, por el otro lado Copi habría mantenido una relación de "distancia" con la cultura y con la lengua de ese país². A través de esa "distancia" Copi habría subrayado siempre su condición de "extranjero" o, al

\footnotetext{
1 Pablo Gasparini (2010) opone el "transgresor francés de Copi" al francés de Bianciotti del que "se dirá que es un francés puro" (9). Comentando unos acercamientos críticos a este uso del francés, Gasparini dice: "parecería ser que el francés de Bianciotti, precisamente por ser un francés aprendido (de un 'extranjero', como significativa y reiteradamente se señala) conseguiría ser un francés 'puro"' (9).

2 Para un análisis más profundo de la cuestión del francés en la obra de Bianciotti, puede consultarse la tesis de doctorado de Claudia Moronell, titulada Héctor Bianciotti en lengua francesa: "la imposible restitución del pasado", defendida en 2015 en la Universidad Nacional de La Plata.
} 
decir de George Steiner, de "extraterritorial"3. La evidencia a la que Steiner apela a la hora de definir a estos "extraterritoriales" es su condición de extranjeros en el seno de una lengua y de una cultura nacionales. En el análisis de la obra de esos escritores que van y vienen entre su lengua materna y la de adopción (por ejemplo Samuel Beckett entre el inglés y el francés, Vladimir Nabokov entre el ruso, el inglés y el francés), Steiner ve una incomodidad que los sitúa en un lugar diferente dentro del canon. Así, según los críticos, Copi sería uno de esos casos de escritor "extraterritorial", pero no solamente porque adoptó otra lengua, sino porque su obra muestra una "incomodidad" con ella. Según Jason Weiss en un texto de 2003, la obra de Copi se situaría en un "más allá" de la diferencia cultural (Weiss 2003, citado por Muslip 2007: 137), lo cual le habría permitido un "uso muy libre de diversas tradiciones, las de sus países de origen, las de terceras culturas y la propiamente francesa, con la comodidad que da el no tener la presión de un lugar claro de pertenencia" (Muslip 2007: 142).

Además del hecho, que no se puede dejar de lado, de que la "imagen de autor"4 de Copi ya es de por sí "anticanónica" como escritor -ya que se construye de una manera atípica, siempre a caballo de las distintas actividades artísticas que llevó a cabo (humor gráfico, teatro, narrativa)-, debe tenerse en cuenta esa posición "extraterritorial" de Copi en la cultura, una posición que estará dada, en parte, porque no se produjo en él una asimilación total a la lengua francesa. Algunos textos críticos han señalado, en ciertos pasajes aislados de sus obras, un uso gramaticalmente incorrecto

\footnotetext{
${ }^{3}$ Me refiero al concepto desarrollado por George Steiner en su obra Extraterritorial: Papers on Literature and the Language Revolution, publicado en 1973.

${ }^{4}$ Entendiendo "imagen de autor" de la manera en la que lo conceptualiza María Teresa Gramuglio en su texto de 1992.
} 
del francés ${ }^{5}$ que indica que se trata de una estrategia "minorizante" (en los términos en que Gilles Deleuze y Félix Guattari hablaban de literaturas "menores"6), como si al usar ese francés se pusiese el acento en la extranjería del que lo habla, o como si el hablante fuese un niño. Después de todo, muchos de los personajes de Copi tienen algo de infantil, tanto por su inocencia y su ingenuidad en algunas de sus actitudes, así como por la obcecación melodramática y extrema que los anima, como también por la crueldad que en muchos casos caracteriza sus acciones, que conforman, dice Isabelle Barbéris, un teatro que es "cruel, cannibale et sentimental" (Barbéris 2014: 19). No se puede dejar de tener en cuenta que, junto con el teatro, la primera "escuela" artística de Copi fue el humor gráfico. Como se ha observado en más de una ocasión, hay algo de caricaturesco en el trazo con el que Copi delinea sus personajes. Además de que el conjunto de su obra dramática demuestra un conocimiento amplísimo de la historia del teatro universal, Copi combina ese conocimiento con su propia habilidad para el dibujo. Hay un comienzo donde las actividades aparecen inevitablemente mezcladas, como sucede en las historietas de sus primeros

\footnotetext{
${ }^{5}$ Pablo Gasparini explica que algo de esta "incorrección" se puede ver en la utilización de hispanismos, como por ejemplo, y tal como, según este crítico, señalase antes Raquel Linenberg en una tesis doctoral de 1988 (que toma especialmente la novela corta L'Uruguayen, de 1973), en "la morfología de los participios pasados, $[\ldots]$, faltas en la sintaxis [...], concordancia verbal [...] y en la elección de algunos pronombres" (Gasparini 2010: 95-96)

6 Los autores desarrollan el concepto de "literaturas menores" en su obra Kafka. Pour une littérature mineure, de 1975. Según ellos, una literatura menor se caracteriza por estar escrita en una lengua "mayor" o "imperial", dentro de la cual aquélla hará un uso minoritario, que la "desterritorializa", según la terminología de los dos filósofos franceses. Es decir, que la lengua "menor", como puede ser el alemán de Kafka, que tiene influencias del checo y del yiddish, y que "minoriza" la lengua mayor o imperial; en la conceptualización de Deleuze que retoma la célebre formulación de Proust, se trataría de escritores que escriben en su lengua usándola "como una lengua extranjera". No se trata de usar una "lengua menor" (porque, después de todo, Kafka no escribió en checo), sino de usar la lengua "mayor" de un modo "menor", por ejemplo abordando temas no relacionados con la cultura "mayor", como Kafka cuando aborda, en alemán, temas que no corresponden a la cultura alemana, sino a la checa.
} 
años en el París de la década de 1960, con La femme assise, en la que más de un crítico ha señalado la filiación con la actividad teatral ${ }^{7}$. Que La femme assise haya sido una de las historias de Copi elegidas para ser representadas sobre un escenario (en la piel de la actriz Marilú Marini ${ }^{8}$ ) obedece no solamente al atractivo que para una gran parte del público francés representaba ese extraño personaje, sino también a un componente teatral que ya estaba en su misma factura ${ }^{9}$.

Esta posición "extraterritorial" de Copi es un motivo importante para que se considere el problema identitario en relación con él. Pero hay otro motivo que directamente torna ineludible ese tema, y se encuentra en el hecho de que en todas sus obras se puede encontrar el tema de la "identidad", ya no sólo nacional, sino más bien de la identidad en general: podemos decir que aparece el tema o que, al menos, su obra es pasible de ser leída desde esta problemática. Ésta se puede ver especialmente en las subjetividades que encarnan los personajes de sus obras, que muestran un rasgo común: su inestabilidad. En el contexto del pensamiento occidental, cuando se habla de la "subjetividad" es inevitable pensar en el Sujeto como epifenómeno del período de la Modernidad: un sujeto que se consolida al calor de las filosofías del Siglo de las Luces, y que según Cristina Molina puede considerarse uno de los "grandes mitos de la llustración" (Femenías 2012: 39). La noción de identidad constituye uno de los vectores utilizados para definir al Sujeto, y esa identidad se caracteriza por la "estabilidad" (Femenías 2012: 39). En cambio, como se decía líneas arriba, la identidad en Copi es inestable, y puede verse no solamente en la imagen de autor que Copi ha elaborado, sino también en la forma de sus personajes

\footnotetext{
${ }^{7}$ Por ejemplo, Marcos Rosenzvaig (2003), César Aira (1991) o Stefano Casi (2012).

${ }^{8}$ Dirigida por Alfredo Arias en 1984 y 1986 en París.

${ }^{9}$ Y al comentar su interpretación de La femme assise, Marilú Marini dice: "[...] yo trabajé La mujer sentada como un dibujo, casi como un esquema corporal" (Tcherkaski 1998: 104).
} 
inclasificables, caricaturescos, y que aparecen sometidos al cambio y a la "metamorfosis" constante ${ }^{10}$. No se trata solamente de que Copi sea un autor que se ubica a sí mismo en un lugar incómodo desde lo cultural o lo lingüístico, sino también que su obra expresa un conjunto de variables que permiten leer esa incomodidad en la forma de personajes, que a su vez están envueltos en acciones que atentan continuamente contra la noción misma de "estabilidad". Es decir, no es solamente la estabilidad de la identidad de Copi como autor (su "figura de autor") la que está en entredicho, sino la de toda identidad que se haya puesto en movimiento en su obra.

Las ficciones de Copi estarán pobladas por "sujetos no-hegemónicos" (como podrían ser denominados en el marco del pensamiento de la llamada "posmodernidad") ${ }^{11}$. Se tratará de personajes que ocupan, en general, los márgenes de la sociedad, que son "alternativos" a lo aceptable por la sociedad burguesa (Muslip 2009a: 6).

\subsection{Identidades de sexo-género}

Pero el tema de la identidad aparece en Copi con más fuerza todavía cuando se lo piensa en relación con la sexualidad y los géneros. Parecería que de ningún modo pudiese analizarse a Copi sin abordar esa dimensión. Cuando Copi realizó la parte más importante de su producción (en las décadas de 1970 y 1980), la cuestión de la "disidencia sexual" estaba presente en Francia ${ }^{12}$, especialmente después de lo que significó mayo de

\footnotetext{
10 En su tesis doctoral sobre Copi (2007), Eduardo Muslip hablará de "metamorfosis" de la identidad, concepto que este investigador toma de una obra de Rosi Braidotti y que se expondrá páginas más adelante en la presente tesis.

${ }^{11}$ El término "sujetos hegemónicos" es considerado en esta tesis a partir de las reflexionesconsideraciones que sobre el tema lleva a cabo María Luisa Femenías (2007) y que se abordarán en el capítulo 1 de esta tesis.

12 Aunque no con esa denominación, "disidencia", que se empezó a usar en años más recientes, como explica Atilio Rubino (2019: 62).
} 
1968 en ese país: es a partir de ese momento, de ese quiebre, que surge un "nuevo tipo de activismo", especialmente homosexual (López 201813) aunque, como veremos a lo largo de esta tesis, en Copi el término "homosexual" y todo lo que esto implica, es problemático. Actualmente, ya terminando la segunda década del siglo XXI, y en un contexto donde la teoría queer está más difundida (o donde, al menos, esta dimensión del pensamiento sobre las identidades ha cobrado una fuerza impensable décadas atrás) y a más de treinta años de la muerte de Copi, todo lector actual se preguntará cuál es la incidencia del "pensamiento" del autor en esta problemática. Además, deben tenerse en cuenta las particularidades de este tema en un país como Francia, donde en ese momento estas reivindicaciones de la "disidencia" tenían un margen de acción aun mayor que el que era posible encontrar en Argentina. Si bien Copi se había exiliado en Francia por motivos personales -ya que, como él mismo dijo en una entrevista realizada para el diario Libération (Tcherkaski 1998: 121-127), él se había ido a París "para ver teatro", y luego decidió quedarse ahí (122)-, a partir de 1974 le fue prohibida la entrada a la Argentina por el escándalo suscitado por su obra Eva Perón (1970). En efecto, la utilización de un actor travestido (Facundo Bo) para representar a quien fuera la Primera Dama argentina, y cuya imagen había sido reconvertida, por esas épocas, en símbolo de la lucha armada de extrema izquierda en nuestro país, fue una piedra de escándalo. La libertad estética que Copi había adquirido en Francia le permitió realizar ese experimento, además, claro, de que fue

\footnotetext{
13 "Mayo del 68 y como parte del mismo contexto, pero un año después, la revuelta de Stonewall, explican la emergencia de una nueva camada de activismo homosexual, que representó una ruptura con las estrategias de las organizaciones que la precedieron. Luego del '68, la homosexualidad emerge como una cuestión política y la liberación sexual como parte de una pelea más general contra el capitalismo y su orden moral y sexual" (López 2018: 26).
} 
escrita a principios de 1969, es decir, pocos meses después del "mayo francés" (Di Fonzo Bo 2017: 6).

Actualmente, parece haber consenso en admitir que Copi genera una literatura queer pero antes de que esa denominación existiese (Lozano 2013: 810), ya que esa visión sobre las sexualidades y los géneros que podemos encontrar en su obra parece adelantarse a las teorizaciones en que los estudios sobre estos temas derivaron a partir de la década de 1990.

Uno de los puntos nodales de la discusión de estas corrientes de pensamiento feministas, gay-lésbicos y queer ${ }^{14}$ se encuentra en la consideración del "sujeto" como construcción de la Modernidad, marcado por un sesgo sexista y privilegiadamente heterosexual, y que debe ser deconstruido para mostrar su carácter falsamente "natural". Que se vincule a Copi con el pensamiento queer responde al hecho de que, como se decía más arriba, no hay nada estable o "natural" en el mundo representado en sus obras ${ }^{15}$. Si bien Copi habría participado en el FHAR (Front Homosexuel d'Action Révolutionnaire) junto con Guy Hocquenghem (uno de los miembros más notorios de esta agrupación) (Di Fonzo Bo 2017: 6) y seguramente también conocía sus teorizaciones (que actualmente son reconocidas como pioneras de esas líneas de pensamiento que podríamos

\footnotetext{
${ }^{14}$ Desde luego, somos conscientes de que el feminismo, los estudios gay-lésbicos y los estudios queer no son lo mismo, pero, a los fines de la presente investigación, se buscará pensarlos en los aspectos que tienen en cuanto a continuidad y no solo en sus rupturas. En un artículo ya mencionado en una nota al pie anterior, Atilio Rubino plantea, aunque refiriéndose solamente a la oposición que suele establecerse entre "el movimiento gay-lésbico de fines de los sesenta y los setentas" y "el movimiento queer de fines de los ochenta y los noventa", que podría dejar de pensárselos como opuestos binariamente, "[...] para repensarlos como una continuidad de la misma lucha contra la normalización, contra la axiomatización del deseo y la producción biopolítica de normalidad y abyección" (Rubino 2019: 64).

${ }^{15}$ En Copi, según lo explica Lozano en una cita que volveremos a utilizar en el capítulo 6, "[...] lo que denominamos naturaleza es una construcción" (Lozano 2013: 810).
} 
llamar queer ${ }^{16}$ ) él siempre tuvo una visión irónica de estas ideas que tendían a politizar el sexo, o al menos eso parece verse si leemos sus obras donde este tema aparece, en las que el humor es omnipresente, o al leer algunas de sus declaraciones en entrevistas ${ }^{17}$. Copi pone en escena figuraciones "disidentes", que salen de las cristalizaciones identitarias de tipo binario que apuntan a normativizar las identidades sexuales y de género y las relaciones de éstas con sus cuerpos. Por eso, a todo esto no es ajeno el hecho de que las ediciones de las obras de Copi, por largo tiempo difíciles de hallar, hayan tenido un resurgimiento en la última década y media, al mismo tiempo que se multiplicaron las puestas en escena de piezas dramáticas suyas en Argentina: contrariamente a lo que sucedía en otros países (como Francia o Italia) donde las piezas de Copi ocuparon con mucha mayor frecuencia las carteleras teatrales.

\subsubsection{Identidad, cuerpo, género. Una intersección problemática}

Los tres conceptos que aparecen en el título de esta tesis se intersectan aquí para realizar un acercamiento crítico a la obra de Copi. Los estudios de sexualidades y de género han estado atravesados por estas tres cuestiones.

De entre esos tres términos, es quizá el de "cuerpo" el que merezca más discusión, en gran medida porque si, como dijimos, la obra de Copi puede considerarse queer, será inevitable que el cuerpo aparezca como problema, ya que este concepto es para las culturas queer una de las piedras angulares de su lucha, prácticamente el "principal catalizador" (López Penedo 2008). En realidad, ya desde antes de que lo queer ganase

\footnotetext{
${ }^{16}$ Según lo explica Beatriz Preciado en su texto "Terror anal: apuntes sobre los primeros días de la revolución sexual" (2009).

17 Como dice en una entrevista en italiano con Sandro Avanzo publicada por primera vez en 1986: "Molti intellettuali gay vivono in un'ossessione omosessuale e vedono l'omosessualità dappertutto" (Avanzo 2008: 196).
} 
espacio en el campo de la discusión sobre las sexualidades, el cuerpo ya había entrado en el debate. En los comienzos de los años 70 es cuando el cuerpo se convierte en un espacio de lucha política (Loyden Sosa y Sánchez Bringas 2007: 74); hasta el momento, el cuerpo aparecía como una superficie física natural sobre la que venían a inscribirse los significados culturales, es decir que el cuerpo aportaba la base física con la sexualidad genital binaria compuesta por los pares "macho" y "hembra", y luego se deducían de estos los dos géneros socialmente aceptados: "hombre" y "mujer". El cuerpo no entraba, por ello, en la discusión, ya que se lo consideraba una superficie neutra. Este enfoque fue cuestionado por su utilización acrítica de las dicotomías como "cuerpo/alma", "materia/espíritu", "biología/sociedad", entre otras (Loyden Sosa y Sánchez Bringas 2007: 75). Así, las teorías feministas y queer que fueron apareciendo luego de los 70 , observaron que los cuerpos son más complejos y heterogéneos que la diferencia binaria basada en la genitalidad. El cuerpo es un nudo donde se intersectan lo privado y lo político, lo natural y lo cultural: el cuerpo ya no es solo el lugar de la diferencia anatómica.

En cuanto a la identidad y el género, ya sabemos que la primera vez que aparecen vinculados es en el contexto de la obra de Robert Stoller, quien en 1968 habló de "identidad de género", para referirse a la forma en que el/la niño/a viven el "saberse varón o mujer desde su más temprana infancia" (Fridman 2007: 175). Pero, así como el cuerpo no es solamente la superficie biológica sobre la que vienen a imprimirse los discursos, del mismo modo el género, en la actualidad, no es considerado como algo meramente cultural. Es cierto, sí, que esa categoría, la de "género", aportó mucho en relación con el estudio de las sexualidades, ya que proporcionó un lente de análisis que antes no existía, dando lugar al mismo tiempo a la posibilidad de considerar la representación "social" del sexo. Sin embargo, 
en este enfoque el sexo subsistía como un dato biológico y universal previo a la cultura y al discurso, mientras que en los enfoques que se fueron dando desde los años 90 en adelante, se empezó a considerar que el sexo (percibido binariamente) está tan determinado por la cultura como lo está el género.

Pero párrafos más arriba se decía que no solamente las identidades de los sujetos son las que aparecen como inestables en Copi, sino también el mundo representado en sus obras, que se manifiesta muchas veces como cambiante, mutable, al borde de la destrucción y la catástrofe. Esto se puede ver especialmente en su obra dramática y en su narrativa, en donde es muy común encontrar sucesos catastróficos y giros bruscos de la acción, que alteran la trama y proyectan a los personajes en un mundo cambiante y en continua destrucción. Ese "mundo" donde conviven e interactúan los personajes aparece en consonancia con lo que ocurre con sus subjetividades, es decir, con sus identidades, pero también, necesariamente, con sus cuerpos y sus respectivas configuraciones de sexo-género.

\subsection{Teatro y teatralidad}

Aunque Copi haya incursionado en varios medios artísticos (dibujo, dramaturgia, narrativa), es quizá uno de ellos, el teatro, a partir del cual resulta más interesante abordarlo, ya que las problemáticas de la identidad, del género y del cuerpo se encuentran en su obra en estrecha relación con una concepción específica de "teatro". Por eso es que algunos críticos no han dudado en considerar que el teatro es en Copi un elemento central, o directamente, como lo define Barbéris, el "foyer organisateur", que en su obra tiene "une place d'épicentre" (Barbéris 2014: 24).

Toda su poética, en realidad, aparece atravesada por la teatralidad, un concepto al que podemos entender, en una primera instancia, de la misma 
forma en que Roland Barthes lo definía en uno de sus Essais critiques (1963): "Es el teatro sin el texto, es un espesor de signos y sensaciones que se edifica en la escena a partir del argumento escrito, esa especie de percepción ecuménica de los artificios sensuales, gestos, tonos, distancias, sustancias, luces, que sumerge el texto bajo la plenitud de su lenguaje exterior" (Barthes 2003: 54). Para Barthes, el teatro sería como la "polifonía", que se opondría según él a la "monodia literaria"; el teatro es el lugar donde distintos "medios"18 (danza, música, pintura, texto, actuación) se dan la mano para componer un mensaje múltiple. Esta idea de teatro estuvo detrás de muchos de los planteamientos que la teoría y la crítica literaria llevaron a cabo en torno a la noción de la "teatralidad" y de la puesta en escena. El siglo XX fue "el siglo de los directores" en el teatro europeo; según Patrice Pavis (2008), podría decirse que en ese siglo se dio una "reteatralización" del teatro, que, contra el naturalismo imperante a fines del siglo XIX, apostó por un teatro que "no esconda sus cartas", que marcara con intensidad sus aspectos "puramente" teatrales (436-437), que dejara al descubierto la "convención", la cual podría definirse, según André Helbo, como "[...] la frontera instalada para diferenciar el universo espectacular de aquello que le es exterior" (2012: 196). Y es por eso que Pavis menciona a Antonin Artaud como uno de quienes ha criticado con más agudeza el retroceso de la "teatralidad" en la "escena europea tradicional" (Pavis 2008: 434): según lo explica Pavis, es justamente en el libro Le théâtre et son double (1938) de Artaud donde se expone la necesidad de recuperar lo propiamente "teatral" del teatro. Si bien la historia del teatro occidental del siglo XX no puede ser sintetizada fácilmente y sus etapas no se pueden generalizar de una vez y

\footnotetext{
18 Aquí se considerará que "medios" puede designar tanto a "medios" en el sentido estricto de "medios de comunicación”, materiales o no, como a "artes”, de la misma forma en que lo hace Chiel Kattenbelt (2008), que prefiere hablar directamente de "medios" (21), tal como se lo aborda, actualmente, en la relativamente nueva disciplina de estudios literarios que se ha dado en llamar "intermedialidad".
} 
para siempre, debemos tener en cuenta que Copi escribe entre las décadas de 1960 y 1980, y que por lo tanto una buena parte del siglo XX ya ha pasado, y el teatro ha tenido una evolución significativa en cuanto a la profundización de esta veta de teatralidad, es decir de ese movimiento de "reteatralización" del teatro del que hablaba Pavis.

Ahora bien, en la definición de Barthes aparece también un concepto en particular, éste es el que se refiere al "lenguaje exterior" del texto teatral; este "lenguaje exterior", en toda su "plenitud", es un "espesor de signos", que tiene que ver, según él, con los "artificios sensuales" que despliega el teatro (los elementos escénicos, por ejemplo, los actores, la iluminación, el sonido, la utilería), es decir, "[...] aquello que, en la representación o en el texto dramático, es específicamente teatral (o escénico)", dice Pavis (434).

Cuando éste se pregunta sobre los sentidos más difundidos de "teatralidad", menciona dos: según el primero, cuando se habla de algo "teatral" se hace referencia a "una escena muy espectacular e impresionante", es decir, algo "espacial", "visual", "expresivo" (Pavis 2008: 434), e inmediatamente el mismo Pavis descalifica este sentido, considerándolo como "banal y poco pertinente" (434). Según el otro sentido, "[...] teatral quiere decir la manera específica de la enunciación teatral, la circulación de la palabra, el desdoblamiento visualizado del enunciador (personaje/actor) y de sus enunciados, la artificialidad de la representación" (Pavis 2008: 434). Los elementos de los que habla Pavis, en especial en el segundo sentido, conforman una manera de definir a la teatralidad como un espacio donde se pone en funcionamiento el proceso teatral; en este caso, esos elementos que enumera Pavis son parte de lo que consideraremos "teatralidad" para esta tesis.

Si exploramos la producción de Copi más allá del teatro, como por ejemplo la narrativa, veremos una presencia de la "teatralidad" que se 
manifiesta, por un lado, en las menciones explícitas (en la fábula) a elementos provenientes de ese mundo; así como una presencia de la imaginería relacionada con lo teatral (el uso del disfraz, la alusión a elementos escenográficos, de utilería, entre otros). Pero, por otro lado, y de un modo menos declarado o manifiesto, parece haber una concepción de la identidad y de los géneros sexuales que muestra una raigambre en los procedimientos teatrales; esta concepción se ancla especialmente en el cuerpo, es decir, un aspecto que forma parte de las preocupaciones del arte escénico (cuando conciernen al actor) pero también, como vimos en el apartado anterior, con referencia a las preocupaciones en torno a los géneros y las sexualidades (más allá del teatro). En muchas obras de Copi, entonces, la teatralidad funciona como una dimensión para leer el problema del cuerpo. Según Erika Fischer-Lichte (comentada por André Helbo), la teatralidad "evoca un trabajo estético particular que consiste no solamente en interpretar un objeto como signo sino en mostrarlo a los otros como signo" (Helbo 2012: 30). Al recibir este "signo teatral", el espectador de una pieza dramática "es la víctima (voluntaria) de una ilusión referencial: cree que ve a Hamlet, su corona y su locura, cuando realmente sólo ve a un actor, su atrezzo y la simulación de su locura”, nos dice Pavis (2008: 419). Cuando René de Ceccaty, traductor de algunas de las obras de Copi, nos dice que en la obra de este autor "todo es signo" (Ceccaty 2007: 17), se refiere, creemos, a esa misma concepción de signo teatral. Desde ese punto de vista, los cuerpos también podrían considerarse "signos" en Copi.

Quizá el recurso teatral más notorio en Copi es el travestismo escénico, que fue utilizado en diversas puestas en escena de sus obras, en algunos casos previéndolo él mismo, en otras siendo decisión posterior e individual del director; se trata de un recurso que está ligado a la teatralidad en su sentido más preciso: el disfraz que sobre él porta el actor genera un 
juego cuyo efecto se debe a eso que Pavis llamaba "el desdoblamiento visualizado del enunciador (personaje/actor)" (2008: 434). Según Óscar Cornago, "[l]a teatralidad hace aparecer la divergencia por debajo de la apariencia de unidad o totalidad, nos muestra la otra realidad que se esconde por detrás de la superficie de la representación -parece mujer, pero es hombre-, y ahí suena la disonancia" (Cornago 2006: 260). Es decir, la disonancia se produce entre el cuerpo y la superficie que lo recubre. Se trata de un juego situado en lo que desde el título de esta tesis llamamos "fronteras de la teatralidad", es decir, entre lo visible y lo oculto, entre lo material y lo imaginario, entre el cuerpo y el disfraz, o entre el cuerpo y el "alma" o "verdad interior". En las obras narrativas de Copi, por otro lado, veremos cambios de identidad que obedecen a ese mismo peso que el travestismo tiene en su concepción del teatro, no sólo por la aparición de personajes travestis propiamente dichos, sino por una consideración de la identidad, de los cuerpos y de los géneros como constructos que funcionan en gran medida a partir del mecanismo del disfraz teatral.

\subsection{Subjetividades "en exilio", subjetividades trans}

Se utiliza aquí el término "fronteras" de manera similar a como lo ha usado Isabelle Barbéris al hablar del teatro de Copi, al que esta estudiosa considera como acorde con la época en que su autor lo produjo, es decir, la misma época en que el pensamiento y el arte occidentales estaban emprendiendo un proceso de erosión del sujeto (Barbéris 2014: 25); para la autora, el teatro de Copi "reproduit de manière presque sismographique certains mécanismes d'inclusion et d'exclusion et, ce faisant, problématise la notion de frontière (frontière du corps, de la scène)" (25). Las fronteras de la escena en Copi aparecen como una forma para problematizar ( $a$ un nivel "sismográfico" como dice Barbéris) al mismo sujeto, las fronteras de cuya 
identidad, de su cuerpo, y de su género, han sido instituidas por leyes que Copi rompe continuamente, y con cuyos restos construye nuevas e inesperadas configuraciones subjetivas.

Estas imposibles configuraciones subjetivas tienen como realización primera la transformación de las identidades, cuerpos y géneros sexuales, la cual se produce de una manera inédita y revolucionaria, pero además puede verse que Copi utiliza elementos pertenecientes a otras zonas de discurso identitarias, como puede ser, por ejemplo, la identidad nacional (la argentina especialmente). Como se decía al comienzo de esta Introducción, aunque Copi haya abandonado su país de origen, "lo argentino" como tema aparece más de una vez en su obra: por ejemplo en la mencionada Eva Perón, o en L'internationale argentine (1988), o en La vie est un tango (1989), o en La sombra de Wenceslao (estrenada por primera vez en 1978), o en Cachafaz (1993) (aunque en esta pieza lo argentino aparezca subsumido en un contexto que podríamos llamar "rioplatense" ya que incluye también a la cultura uruguaya). Las individualidades que analiza Copi en la forma de personajes son subjetividades "en exilio", como dice el crítico italiano Marco Pustianaz, refiriéndose a la experiencia de vida "diaspórica" de Copi ${ }^{19}$; como se verá más adelante, se trata de un exilio no solamente de su país de origen, sino además de su base "ontológica"; cuando Copi aborda lo nacional, las marcas de esta identidad aparecerán con frecuencia tematizadas a partir del estereotipo y de su inflación exótica característica, es decir, modos de representación que conforman formas saturadas culturalmente, y en las que Copi subraya su carácter contingente, y ya para siempre en ruinas.

\footnotetext{
19 En realidad, Pustianaz está comentando un texto de David William Foster del año 2000, "La diáspora homoerótica en la literatura latino-americana"; en este texto, Foster relaciona el exilio de Copi con el de otros escritores latinoamericanos, y considera que esta experiencia es central en la "produzione perversa di soggettività ‘fuori centro' e 'fuori misura', ivi compresa quella sessuale e di genere” (Pustianaz 2008: 34).
} 
El travestismo, junto con otras manifestaciones disidentes, lleva a pensar muchas veces en el vocablo "transgénero", una palabra que actualmente se usa para englobar todo un conjunto de diversas subjetividades y orientaciones sexuales, que en más de un momento de la obra de Copi tienen su manifestación. Y si el sujeto "trans" que aparece con más fuerza en Copi es la/el travesti, posiblemente esto es debido a la importancia que ha tenido el recurso del travestismo escénico en la historia del teatro desde la Antigüedad. Pero también encontraremos otros sujetos "trans", como transexuales, o intersexuales, en los que la mutación es constante y donde no se podría hablar de una identidad fija o esencial. Paradójicamente, la mutación es lo único fijo en el mundo de Copi, y por eso toda su poética podría considerarse "transgénero". Daniel Link dice algo similar al sugerir que en la obra de Copi nos encontramos con "una ética y una estética trans: transexual, transnacional, translingüística" (Link 2009a: 383). Fuera de toda sexualidad definida, pero también de toda identidad nacional y de toda lengua (sea el francés o el castellano).

\subsection{Preguntas e Hipótesis}

Teniendo en cuenta esto último, y volviendo al inicio, en el que traíamos a colación aquella pregunta tantas veces formulada en torno a la obra de Copi y su pertenencia a alguna literatura nacional, cabe preguntarnos: ¿cómo podría definirse esa pertenencia en Copi, esa identidad, cuando su obra emite, precisamente, un discurso constante de subversión de las identidades? $\mathrm{Y}$ junto con esta última pregunta, podemos formular otra que movilizará la argumentación en esta tesis: ¿de qué modo el problema de la inestabilidad identitaria (y de los géneros sexuales, y de los cuerpos) implica o articula los procedimientos artísticos que Copi pone en movimiento? $\mathrm{Y}$, aun más allá: ¿cuál es el papel o la importancia que esta teatralidad tiene 
en el conjunto de su obra? ¿Cúales son las "fronteras" de esta teatralidad que operan como "fronteras" de la identidad, el género y el cuerpo?

Por lo tanto, se partirá de la hipótesis de que, en Copi, los elementos con los que se compone la identidad aparecen sometidos a un proceso de desestabilización, y que eso se verifica en una ficción (teatral y narrativa) que pone el énfasis en elementos relacionados con la teatralidad, donde ésta se transforma en el vehículo estético por excelencia para expresar estos cambios: de este modo, los cuerpos, los géneros, las identidades obedecen a una mecánica que es propia del teatro, y viceversa, ellas resultan imprescindibles en la elaboración de esa poética "teatral".

\subsection{Estado de la cuestión}

Los interrogantes que despierta la "teatralidad" en la obra de Copi han sido puestos de relieve en numerosos trabajos críticos que abordan el tema de distintas maneras, algunos dedicándole más atención, otros subsumiendo el problema dentro de otro tipo de problemáticas que suscitan las obras del autor. En cuanto al travestismo, la mayoría de los trabajos que tocan el tema reconocen la importancia que tiene para el teatro, no sólo en cuanto a los personajes que encarnan subjetividades travestis, sino en la función que ha tenido el travestismo como opción de puesta en escena en las distintas adaptaciones teatrales que hubo de su obra. Todos reconocen la importancia que la teatralidad tiene en la construcción de las identidades de Copi, tanto en el género teatral propiamente dicho como en sus cómics y en su narrativa. Algunos de los trabajos críticos no desarrollan exhaustivamente el problema, pero dejan intuir pistas o preguntas que se abren, o hipótesis sugeridas lateralmente. 
0.6.1. Existen dos estudios que, por su carácter pionero, su agudeza y su conocimiento profundo de la obra de Copi y de la importancia que el género teatral tiene en la totalidad de la misma, deben ser mencionados en detalle. En primer lugar, el libro Copi (1991), de César Aira, que recoge una serie de conferencias dictadas en 1988, y luego Copi: sexo y teatralidad (2003), de Marcos Rosenzvaig, que es fruto de una tesis doctoral. El primero de ellos, César Aira, ve en Copi un autor "barroco" (1991: 29), debido a que su obra muestra un conjunto de mundos que se incluyen unos en otros como "teatros sucesivos" donde cada uno está envuelto en su propia representación (29). A ellos responderán los constantes juegos de disfraces y de cambios de identidades que encontramos en Copi. Por eso el teatro será un eje vertebrador de toda su poética, que sería un precedente de cualquier otra de sus manifestaciones (13). Así, el travesti ${ }^{20}$ sería, para Aira, aquel que se envuelve en una representación, ya que lo que copia el/la travesti no es una mujer real, sino una imagen de la misma, dado que la mujer es de por sí "mujer-imagen" (56), cuya representación siempre será una mentira o impostura construida (107). Todo esto que ve Aira en Copi apunta a poner de manifiesto este "teatro del mundo" barroco (47-48). Habría un tema que, sin embargo, es totalizador en Copi, y es según Aira la transexualidad (105), concepto que Aira no profundiza.

En el segundo estudio extenso dedicado a Copi, el de Marcos Rosenzvaig, se insiste en esa importancia de lo teatral, al decir algo similar a lo dicho por Aira al sugerir que todo en Copi estaría disfrazado (2003: 19), estando así marcada su obra por el juego constante de apariencia y realidad (33) y donde por lo tanto todo se teatraliza (117), todo devela ser siempre

\footnotetext{
20 Aira dice "un travesti". Su texto es anterior a la reivindicación lingüística lograda por "las travestis" en Argentina, quienes consideran que se les ha de tratar de "ellas" puesto que su "identidad de género" es femenina.
} 
una representación de algo, y también se marca continuamente el carácter de representación y artificio que constituye el mundo para este autor. Así, las identidades mostrarían ser también una representación, como se puede ver en el caso de las identidades sexuales, a cuyo análisis Rosenzvaig le dedica más espacio que Aira. Con respecto al travestismo, Rosenzvaig lo define como el epítome de la teatralidad (126), y a su vez lo toma como un espacio "intermedio" que transversaliza toda su obra (58), ya que define un itinerario de transformación que oscila entre lo femenino y lo masculino, entre macho y hembra, pero también entre real e imaginario (58). La exageración de la actuación propia del/la travesti es lo que permite esas transformaciones. Tanto este aporte como el de Aira serán importantes para el trabajo presente, ya que aportan la idea de que el mundo representado por Copi no persigue una mimesis naturalista, sino que busca la exageración y las marcas de la teatralidad para hacer hincapié en el carácter de artificio que tiene toda representación, que es aquello que también estaría en juego en el travestismo, ya que en él se trata de una representación pero que no busca el transformismo total, sino la coexistencia, en un mismo cuerpo, de signos masculinos y femeninos, lo cual desestabiliza las nociones de género. Aunque Rosenzvaig considere al/a la travesti como la subjetividad teatral por excelencia en Copi, de todos modos nombra otras variantes contrarias a la norma heterosexual que se dan en ella. Ambos coinciden también en el carácter de "imagen" que tiene para Copi la representación de la mujer. También es importante agregar que Rosenzvaig considera que la actuación travesti no tiene que ver con la apropiación de la "mujer" sino con la reinscripción en su cuerpo del "exceso" de mujer, del exceso de "femineidad" (2003: 37). 
0.6.2. La perspectiva teatral y la cuestión de los géneros sexuales en la obra de Copi no es abandonada por la crítica posterior, pero incluye en su consideración matrices teóricas provenientes de los estudios sobre gender en el marco de la "posmodernidad", dando así cabida a teóricos como Judith Butler. De este modo, José Amícola (2000), director de este trabajo, describe a Copi como parte de una estética y una sensibilidad camp, no sólo porque su obra parece originarse como lenguaje endógeno surgido del ghetto gay, sino por el hincapié que las obras de Copi hacen en lo teatral. Según Amícola, a Copi el teatro le habría sido sumamente productivo en tanto en el mismo es posible desmontar, por medio de la mostración visual, el juego de máscaras del que se compone el gender (77). En esto, Amícola realizaría un aporte a las célebres observaciones de Susan Sontag sobre el camp en 1961, al agregar un posible efecto político que tendría el camp como juego con las imposiciones de gender, ya que, teniendo en cuenta las teorizaciones que sobre el cuerpo realizase Foucault y que continúa Judith Butler, el cuerpo es no sólo una entidad física, sino discursiva, en la medida que sobre él se traza un palimpsesto que evidencia la fuerza con que los dispositivos de subjetivación forman los cuerpos: uno de esos dispositivos sería el género (30). El amor por el artificio y la exageración que Sontag encontraba en el camp como motivación del trabajo obsesivo sobre lo material, lo decorativo y el melodrama, no tiene en realidad nada de "superficial": será superficial porque trabajará con las superficies, pero Amícola observará que ese trabajo sobre las superficies corporales, vestimentarias, cosméticas y decorativas, conlleva más bien una explosión de la capa discursiva, que por medio de la parodia de todas las marcas de género realiza una desestabilización de las mismas.

El/la travesti en Copi sería la encarnación de la mujer fantasmática del camp, es decir, una mujer que posee pene y que no padece las molestias 
de la menstruación (Amícola 2000: 77). La mujer es el objeto privilegiado de la representación en Copi, pero siempre será, al igual que la conceptualizan Rosenzvaig o Aira, una "mujer-imagen". Una de las razones de la elección de ese objeto de representación tiene que ver con que el cuerpo de la mujer sería el lugar donde se ha creìdo ver tradicionalmente el sentimiento de la histeria, que es lo que distingue al melodrama; según una idea que Amícola toma de un texto de Peter Brooks del año 1976, el melodrama marca los cuerpos, los sobredetermina, del mismo modo en que la histeria marca el cuerpo femenino. Al representar, el camp acentuará el melodrama y la teatralidad que se tensan en los cuerpos, desarrollando, por medio del discurso paródico (78), un desmontaje de esos elementos que los sobredeterminan: se trataría, en la óptica de Amícola, de hacer del cuerpo el centro de la protesta, pero utilizando la misma máscara que el cuerpo asume o que le es impuesta (75). El cuerpo travesti sería, así, una forma de reocupar subversivamente la cadena significante (85). Aunque esta investigación no busque analizar lo camp, serán útiles para la misma estas reflexiones, ya que ayudan a describir no sólo el travestismo en Copi, sino también todo el acento que en Copi se pone en los mecanismos de representación propios del teatro, así como el hincapié en lo material en el sentido de superficial, cosmético o vestimentario, ya que no se trata de una repetición, sino de una resignificación de elementos de la cultura en clave travesti, y que se realiza sobre los aspectos más relacionados con la "capa imitativa" (Amícola 2000: 55). Amícola cita a Fabio Cleto, quien en un libro sobre camp del año 1999 hablará de "afeminamiento" en este tipo de manifestaciones, antes que de "femineidad" (1999). Amícola también ve ese trabajo sobre el artificio y la imitación en una obra narrativa como La guerre des pédés (1982) de Copi, donde determinadas descripciones demuestran el exceso decorativo y su poder de imitación, pero en tono irrisorio, 
mostrando la artificialidad del conjunto (2000: 86). Paulo César Thomaz (2010) retoma la hipótesis de Amícola y observa también esa importancia dada a la vestimenta, que se visualiza como una discursividad, y la combina con la hipótesis sobre el travestismo que Severo Sarduy propusiese en su libro La simulación (1982), según la cual el travestismo sería algo más que una simple manía cosmética, más bien ésta sería una de las fronteras aparentes de una metamorfosis que en realidad no tiene límites. Thomaz observa cómo Copi en la misma novela que cita Amícola, La guerre des pédés, pone en escena un continuo de transformación entre humanos, animales y naturaleza que tiene relación con los temas centrales de esa novela (el travestismo y el hermafroditismo), y que allí puede verse esa "metamorfosis ilimitada" al decir de Sarduy, que desestructura la "lógica binaria identitaria dominante" (Thomaz 2010).

0.6.3. Los textos de Daniel Link son muy importantes para leer a Copi actualmente. Este crítico escribe sobre Copi desde los tempranos 2000. Sus textos del año 2005 y 2009 (a), especialmente, ponen el énfasis en una posible ubicación de Copi en la tradición literaria argentina. Este crítico pone de manifiesto la importancia que tiene el dispositivo teatral en toda la obra de Copi, y su relación con su concepción ontológica, que tiene que ver con una "transexualidad originaria y básica".

El autor recoge todos sus textos sobre Copi en una obra titulada La lógica de Copi, publicada en 2017. Uno de los aportes más interesantes para entender la "lógica" de Copi es comprender que la identidad en su obra responde a un corrimiento de las "clases" (como resultado de las clasificaciones); la antropología de Copi es "montruosa", para Link, y en eso se basa su poética. Por otro lado, será de suma importancia en esta tesis el 
uso que este crítico hace del término "trans", tal como ya se adelantó en el apartado 4 de la Introducción.

0.6.4. Otra tesis doctoral que realiza un gran aporte a los estudios sobre Copi es la de Eduardo Muslip, defendida en la University of Arizona en el año 2007, y que se titula La producción narrativa, dramática y gráfica de Copi: las metamorfosis de la identidad. Bajo el concepto de "metamorfosis", que Muslip toma de Rosi Braidotti, Muslip analiza casi la totalidad de las obras de Copi, mostrando el modo en que el autor desmantela y reconfigura los constructos identitarios, tomando una perspectiva "posmoderna", e incluso queer. Los constructos que Muslip considera son los de "sexogénero", "cuerpo", "memoria”, "política” y "nación”. El aporte más interesante de esta tesis es la manera en que el autor pone en relación la cuestión de lo sexo-générico y los demás constructos identitarios: la relación estrecha que en la obra de Copi entablan estos aspectos es una de las ideas más fecundas de Muslip y que se han tomado como una de las ideas rectoras de esta tesis. Aquí se profundizará aún más en las ideas de Muslip, dándole más atención, además, al concepto de travestismo, al que el autor examina como una parte más de las "metamorfosis" de la identidad sexual.

0.6.5. Isabelle Barbéris es uno de los críticos que han hecho lecturas más interesantes sobre la obra de nuestro autor, y centrándose en el teatro, que aborda en profundidad en su tesis doctoral de 2007, Copi : le texte et la scène : mimèsis parodique, mise en scène de soi et subversion identitaire dans les années parisiennes (1962-1987), y publicada en una adaptación en libro en 2014 (titulado Les mondes de Copi. Machines folles et chimères). Especialmente importante es su análisis de los distintos "moldes" teatrales de Copi, para lo cual la autora realiza un análisis profundo de las diversas 
raigambres de la dramaturgia de Copi. Para la presente tesis son fecundos sus análisis del "cuerpo" en Copi, que aparece figurado como una entidad "sans dedans ni dehors" (Barbéris 2014: 90). Para Barbéris, todo en Copi aparece reducido a "sa dimension de spectacle" (50). Otros aportes de esta autora se encuentran, por ejemplo, en su artículo de 2008 (ver el siguiente apartado), donde se interroga sobre el sketch como una "unidad elemental" en la poética de Copi. Y también en un artículo de 2006, donde se analiza la puesta en escena de las obras Le Frigo y Loretta Strong, en las que actuó el mismo Copi desempeñando el arte del transformismo; Barbéris señala que el cuerpo travesti es "corps passage", que opera la puesta en contacto del objeto y del sujeto, pero también de lo alto y lo bajo, de lo familiar y lo extraño, de lo vivo y lo muerto, de lo esencial y de lo irrisorio (2006: 219).

0.6.7. En 2014 se edita un libro en Italia, enteramente dedicado a Copi, y que se titula I/ teatro inopportuno di Copi. Este libro ha sido compilado por el crítico italiano Stefano Casi, y en esta tesis se tomarán en cuenta varios de los aportes allí contenidos, especialmente el de Marco Pustianaz, donde se explora la concepción del sujeto en Copi, y cómo esta se vincula con el travestismo en su obra, y con la dimensión de la histeria como inscripción corporal (en una línea parecida a la que explora José Amícola); luego, se encuentra el texto del mismo compilador, donde aborda un problema fundamental tanto para el teatro en general como para nuestra tesis en particular: la cuestión del espacio, que aquí abordaremos como el espacio teatral pero también como espacio mental, lo cual reenvía a nuestro interés principal de las identidades. A su vez, en esa compilación se encuentra un texto de Barbéris citado en el apartado anterior, así como dos entrevistas realizadas al autor por Jerry Bauer y Sandro Avanzo respectivamente. A su 
vez, también encontramos allí un texto de Daniel Link, ya publicado antes en 2009.

0.6.8. Existen otras tesis doctorales dedicadas a la obra de Copi, que, si bien no son tomadas o citadas aquí, sí deberían mencionarse. Por ejemplo la tesis de Renata Pimentel Teixeira (Brasil, 2007), donde habla de una "escritura transformista" en este autor, tomando el concepto de "máscara" de manera permanente durante la investigación. Esta autora hablará, así, de una perspectiva que aquí se ha tenido en cuenta de modo lateral, y se trata de la "ficcionalización de sí". La idea, repetida por varios críticos, y ya mencionada en los apartados introductorios de la presente tesis, de que en Copi se pone en escena una "erosión del sujeto", es tratada en profundidad por esta autora, que analiza el universo del autor y los procedimientos que esta autora denomina como "transformistas".

Otra de las tesis mencionadas es la de Patricio Pron (Alemania, 2007) donde se hace un análisis de la narrativa completa del autor, utilizando herramientas de la narratología. La perspectiva de la presente tesis es diferente de la de Pron, ya que este investigador no aborda especialmente el teatro; aunque no lo hayamos citado más que en alguno momentos aislados, no pueden dejar de destacarse aquí los aportes que este autor hace a la lectura de la narrativa de Copi, sobre la que la presente tesis se detiene por momentos. Se han tomado algunas consideraciones generales que este investigador hace. Debemos destacar también las reflexiones que hace el autor sobre la pertenencia de Copi a alguna literatura "nacional": Pron ubica a Copi en una especie de línea "alternativa" a la tradición literaria argentina anterior. Hay otros autores que estudian esta perspectiva, y son Verónica Delgado (1996), Graciela Montaldo (1991), Ilse Logie (2005), el mismo Muslip (2007), Pablo Gasparini (2006 y 2010). Todos estos autores 
reflexionan acerca de la posible inscripción de Copi en la literatura argentina, y de sus operaciones de transformación identitaria.

Otra tesis es la de Joanne Pol, defendida en 2010 en Estados Unidos, y que se titula Queering Latin American Theater: A Panoramic Study And Its Performative Implications. En ella se aborda a Copi, pero se lo hace junto con otros autores latinoamericanos; de Copi, la única obra que se aborda es Cachafaz. El análisis que hace esta autora profundiza en la posible consideración del término queer para hablar de teatro latinoamericano. Se trata de un teatro que, según ella, desestabiliza las categorías binarias de género: en su tesis también se utiliza el término "teatralidad" en relación con "identidades".

Otra tesis de importancia es la de María Laura Moneta Carignano (2011, Brasil) donde se aborda a Copi junto con Néstor Perlongher, como parte de una misma corriente de autores argentinos cuyos proyectos estéticos coinciden cronológicamente con el período pos-dictatorial. Ambos son estudiados desde la perspectiva del neobarroco (o del neobarroso), y formando parte de un discurso artístico que subvierte las identidades.

\subsection{Organización de la tesis}

En la sección de Introducción (numerada "0", cero), se presenta el problema a estudiar dentro de la obra de Copi, así como las Preguntas de Investigación (junto con la Hipótesis), y el Estado de la Cuestión.

En el capítulo 1 (“Sujetos no-hegemónicos") se describe cuál podría llegar a ser la concepción general del "sujeto" en Copi en relación con el feminismo y los estudios de género, y cómo de algún modo su idea de lo "abyecto" atraviesa toda su obra.

En el capítulo 2 (“El 'mundillo' y el 'mundo'), se habla de cómo Copi pone en escena la "homosexualidad" en sus obras, tomándola como una 
construcción que, si bien ha tenido un origen como categoría "patologizante", también ha servido como etiqueta de reivindicación identitaria; aquí se comenta cómo Copi reacciona, artísticamente, ante esas definiciones.

En el capítulo 3 ("Sujetos en tránsito"), se toma en consideración la posible dimensión "trans" (o "transgénero") de la obra de Copi, entendiendo esa categoría como una provisoria superación de las construcciones binarias, y a su vez discutiendo la posibilidad de aplicar esta categoría de manera retrospectiva a la obra de este autor, y viendo de qué manera ella atraviesa y configura el plano puramente "estético" de su producción.

En el capítulo 4 ("Cuerpos en escena"), se empieza a orientar el trabajo hacia el tema de la "teatralidad"; en esta parte se habla del travestismo, pero pensado especialmente como recurso teatral, y cómo es imprescindible para comprender la estética de Copi, no sólo en el teatro propiamente dicho, sino en toda su obra en general, se use o no el travestismo escénico.

En el capítulo 5 (“El teatro y la 'acción'”) se explora la importancia central del teatro en su obra, y de lo que podríamos llamar el "aparato" o "dispositivo" teatral en su conjunto, es decir, del teatro como aparato productor de efectos, y a su vez de la metateatralidad; veremos cómo Copi discute con experiencias más o menos contemporáneas a él, como es el happening; por esto, se hará alusión al teatro en el contexto de mayo del 68 y a la visión irónica que Copi hace en una obra teatral suya, La nuit de madame Lucienne.

En el capítulo 6 (“Jean Genet y los vestidos de Eva"), se comentan algunas obras de un autor que ejerció una gran influencia en Copi, en especial en cuanto al uso del travestismo, y de cómo Copi parece dar una versión diferente de este recurso, a partir de un vaciamiento del carácter "religioso" que caracterizaba a ese antecesor. De este modo, se busca mostrar cómo 
Genet es imprescindible para entender a Copi y su concepción de la identidad, el cuerpo y el género a partir del teatro.

En el capítulo 7 ("Espacios escénicos y espacios subjetivos") se aborda el problema del espacio, entendido a partir de la separación entre "espacio mental/subjetivo" y "espacio corporal"; la noción de "espacio", fundamental en el teatro, es analizada aquí como una dimensión ineludible en Copi; a partir de su utilización del "espacio escénico" como una extensión del "espacio subjetivo", Copi problematiza esa separación clásica entre "cuerpo" y "mente", o, si se quiere, entre "cuerpo" o "exterior" e "identidad" o "interior" de la persona, lo cual nos lleva directamente al problema de la "identidad de género"; todo esto aparece atravesado, como veremos, por la cuestión del travestismo.

En el capítulo 8 ("Más allá del teatro") se discute brevemente cómo aparecen figurados el "cuerpo" y el travestismo más allá de la escena, es decir, en otras obras del autor que no pertenecen al teatro, especialmente la narrativa. El propósito fundamental del capítulo se encuentra en la consideración del problema "teatral" en una dimensión que podríamos denominar como "extra-teatral", es decir, que la pregunta que articula este capítulo es: ¿cómo los elementos que constituyen la "teatralidad" aparecen en las obras no estrictamente estrictamente teatrales de Copi?

En el capítulo 9 ("Los hombres de la literatura argentina"), se busca ampliar el análisis incluyendo el tema de la "masculinidad" y de lo "argentino" en Copi, pero tomando para eso la forma en que el autor utiliza los estereotipos representados en la literatura argentina, especialmente en el teatro. A partir de esto, se busca ver cómo lo "nacional" aparece en Copi como un elemento también atravesado por su concepción de la "teatralidad" y del "travestismo", y de cómo este gran bloque identitario de la "nacionalidad" es 
también una construcción esencialista que puede ser leída desde el lente del "género sexual".

En el capítulo 10 se exponen las "Conclusiones" del trabajo de tesis. 


\section{CAPITULO 1 \\ Sujetos "no-hegemónicos"}

\subsection{El sujeto y su caída}

En la introducción de su tesis doctoral (2007), Eduardo Muslip observa que la obra de Copi es importante para la crítica contemporánea porque permite pensar sobre inquietudes propias de ésta, en especial aquellas que se refieren a los fenómenos de "cruce cultural" (debido a la ubicación incómoda de Copi en la tradición artística y literaria, en un lugar intermedio entre las culturas francesa y argentina, que lo sitúa ya de entrada como un escritor de difícil asimilación a un canon "nacional"), pero también en relación con los problemas de la subjetividad contemporánea.

El problema de la subjetividad tomado por el pensamiento contemporáneo se inscribe en el conjunto de reflexiones suscitadas en el marco de la llamada "posmodernidad". El feminismo fue uno de los movimientos sociales que más pensó sobre este problema, en especial el feminismo posmoderno. En realidad, no es que los feminismos anteriores no se preocupasen por la subjetividad, pero es distinta la modulación que tomó el problema en la posmodernidad. En un estudio sobre el problema del sujeto en relación con el feminismo, María Luisa Femenías (2012) se pregunta acerca de la posmodernidad: “ ¿A qué nos referimos cuando decimos posmodernidad? ¿Nos referimos al deconstruccionismo de Derrida? ¿Al psicoanálisis de cuño lacaniano? ¿A Foucault? ¿A cuál de sus etapas?” (39). Sería difícil dar una respuesta unívoca ya que, dice la autora, la posmodernidad "es más bien un cúmulo de problemáticas y un estilo filosófico más o menos identificable y redundante: un ethos, según la expresión de Cristina Molina, que desafía los grandes mitos de la llustración: 
sujeto estable, posibilidad de alcanzar objetivamente la verdad y el conocimiento racional del mundo, y reconocimiento del sentido general de la historia" (Femenías 2012: 39). Así, continúa Femenías más abajo, "si el humanismo es esencialmente metafísico, la posición posmoderna es antimetafísica. Si el despliegue de la metafísica culmina en una cierta concepción de la subjetividad, la posmodernidad la niega como un constructo factible" (Femenías 2012: 39-40). La misma suerte corrió el movimiento feminista, que en un principio se ocupó de la búsqueda de la "igualdad", del reconocimiento de la mujer como "sujeto", como persona capaz de decidir y de acceder a los mismos derechos y privilegios que los hombres, pero luego, en momentos más recientes (al menos en algunas de sus corrientes), tendió a criticar, o a buscar el socavamiento, del sujeto del feminismo como factible. El feminismo posmoderno ataca las bases sobre las que se asienta ese sujeto, poniendo el acento en una característica de su composición: ese sujeto es, en principio y por definición, "varón racional y libre" (Femenías 2012: 40), y, por esa definición, quedaban excluidas las mujeres, ya que la Razón aparecería siempre como un atributo del Sujeto masculino, mientras que lo irracional habría sido desde siempre adjudicado a la mujer.

Pero, si bien la mujer fue la preocupación inicial del primer feminismo, a partir de la segunda mitad del siglo XX fue surgiendo otro feminismo que intentó incorporar en su perspectiva la consideración de otras "minorías". La mayor ampliación del feminismo se produce cuando se dan otras búsquedas, como aquellas que se encuentran en el campo de lo que se conoce como estudios "gay-lésbicos". Sin embargo, las discusiones originales del primer feminismo conservan un núcleo de pensamiento que aún se halla vigente, y ese núcleo se encuentra en la atención crítica que reclama para sí el sujeto moderno. Los estudios "gay-lésbicos" encuentran a 
fines de la década de 1960 una "playa" cultural en la que pueden desembarcar y trabajar, y esto fue posibilitado por el feminismo (Bellucci y Rapisardi 2001: 198). La obra de Copi coincide cronológicamente con este contexto de lucha, y por ello, quizá no sea casual la visibilidad que las identidades disidentes tienen en la obra de este autor, tanto en sus piezas teatrales, sus novelas y cuentos, y su humor gráfico. $Y$, jugando con los términos, la "Razón", no parece algo muy cercano a sus personajes, que se muestran en general como "irracionales". Hay algo de excesivo siempre en ellos, en el sentido de que exceden continuamente sus límites: son sujetos excéntricos, salidos "de-sí" (Pustianaz 2008). Al referirse a los personajes de Copi, Isabelle Barbéris ha hablado de una presencia, en el plano de la fábula, de estados afectivos que, como espectadores o lectores, reconocemos como pertenecientes la esfera de "...nos états actuels de saturation (états borderline, bipolaires et autres burn out)" (2014: 15).

Pero cuando Muslip habla de sujetos “inestables", no se está refiriendo solamente a los sujetos de sexo-género, sino a todo un espectro de sujetos a los que, precisamente, se les niega el acceso a ese estatuto. La deconstrucción del Sujeto moderno no se limita a mostrar solamente a ese Otro invisibilizado, la Mujer, sino a todo aquello que es expulsado de la Humanidad, aquellos "otros" obliterados por el discurso moderno. Con la Modernidad, dice Rosi Braidotti, emergieron también, junto con el Sujeto, todo un conjunto de contrasubjetividades que fueron reducidas a representaciones metafóricas que las subyugaron al convertirlas en objetos de conocimiento. Pero esas contrasubjetividades vuelven a posicionarse para decir algo en contra de esa Modernidad:

La posmodernidad está marcada por el regreso de los "otros" de la modernidad: la mujer, el Otro sexual del hombre, el Otro étnico o 
nativo del sujeto eurocéntrico y el Otro natural o terrestre de la tecnocultura emergen como contrasubjetividades. Dada la importancia estructural de estos "otros" como atrezos que confirman a lo "mismo" en su posición de sujeto dominante, su "regreso" coincide con una crisis de las estructuras y de las fronteras de la subjetividad clásica, lo cual desafía sus propios fundamentos (Braidotti 2005: 148).

En la obra de Copi esos Otros tienen un gran protagonismo, y no se limitan a figuras que representen la disidencia desde lo genérico-sexual, sino que también pueden entenderse como aquellos que son considerados "Otros" desde el discurso eurocentrista, como por ejemplo los inmigrantes (especialmente de los países de África), o también, aquellos "Otros" de la Razón, como son los animales (las ratas, especialmente). Según una de las hipótesis principales de la tesis de Muslip, los procesos de transformación que siguen en Copi las subjetividades de sexo-género pueden pensarse como metáforas del cambio en todos los demás espectros, como si el sexo y el género fuesen una especie de lenguaje que sirve a Copi para expresar esa metamorfosis constante (2007: 7). Como ya se ha comentado en el "Estado de la cuestión" de la presente tesis, Muslip sigue a Braidotti: en efecto, es de un texto de la filósofa italiana de donde él toma el término "metamorfosis"; así lo explica él mismo, como se puede ver extensamente en esta cita:

La idea de metamorfosis, en biología, está asociada con seres de orden "inferior" como los insectos, no con los de orden "superior", como los mamíferos, en que los cambios son menores y muchísimo más lentos. Cuando se trata de los seres más 
evolucionados, la idea de metamorfosis —desde la tradición clásica, con la figura central de Ovidio- parece responder a causas siempre extrañas, explicables sólo desde lo mítico o lo religioso: siempre hay algo misterioso en lo que causa el cambio. En Copi está el principio biológico de la metamorfosis como algo reservado a los seres inferiores, que, al darse en los seres humanos -al transformarse sus cuerpos radical y velozmentesubraya una idea de degradación, y está también el principio mítico de indeterminación en las razones que generan el cambio. A nivel de las acciones dramáticas se da un mecanismo similar: las acciones parecen mutar y engendrar nuevas, pero a partir de una causalidad que siempre se escapa al control racional. Hay algo de "naturalidad" en la sucesión, pero se sabe que lo natural no necesariamente supone lo lógico.

[Rosi Braidotti] [o]bserva la velocidad y eficiencia con la que se efectúa la transferencia de información entre las comunidades de insectos, lo que acerca a estos animales a un modelo elaborado por la tecnología electrónica. Observa también la velocidad y los variados mecanismos de reproducción, que la lleva a categorizar la sexualidad de los insectos como queer [...]. Toma de Steven Shaviro el hecho de que el mundo de los insectos es para los humanos algo que no puede ser ni asimilado ni expulsado [...]. Estos elementos se vinculan directamente con la obra de Copi: la presencia de la velocidad en su dispositivo narrativo, las variadas formas de representación de lo sexual (y también de las formas de reproducción), la creación de personajes que expresan formas de lo humano que la sociedad no puede terminar de asimilar ni expulsar. Además, la dificultad para formular una idea de 
subjetividad en insectos, cuya cualidad de "vivos" se define sólo por su actividad, tiene un correlato en los personajes de Copi: son seres que necesitan todo el tiempo expresar su propia existencia mediante la acción continua, o mediante la intervención verbal permanente (Muslip 2007: 28-29).

Las transformaciones de tipo sexual parecen ser importantes en la argumentación de Muslip, porque, como decíamos más arriba, pueden pensarse como la puerta a todas las demás transformaciones. Como si el primer elemento de reconocimiento de un ser humano fuese la sexualidad, y donde por lo tanto debería empezar su proceso de metamorfosis. En los primeros libros de Judith Butler, se hablaba de que la sexualidad y el género son, en rigor, las matrices iniciales a partir de las cuales se percibe o se concibe todo ser humano (Femenías 2012: 34), “...porque el presupuesto de un sexo biológico binario es la norma regulatoria que cualifica a los cuerpos de por vida, inscribiéndolos dentro del dominio de la inteligibilidad cultural" (Femenías 2012: 34). Según lo advierte Butler, la clasificación en un sexo o un género implica una inclusión en la Humanidad, pero también una exclusión de aquellos que no se adaptan a esa clasificación, y en ese sentido todos esos otros "diferentes" corren la misma suerte que los excluidos de las categorías de género binarias. Pero, comenta escépticamente la misma Femenías:

[...] si bien es claro que siguiendo en parte a Lacan e Irigaray, Butler sostiene que la Ley del Sexo invisibiliza a las mujeres, no queda claro cómo esta Ley fundante de la inteligibilidad de la cultura occidental determina también la exclusión por clase, raza o religión. Podríamos arriesgar al menos dos posibilidades: o Butler 
debilita la causa del feminismo en pro de las nuevas vertientes multiculturales o de las minorías sexuales, o Butler supone que el feminismo ya cumplió con sus objetivos, y ahora debe extender sus logros a otros grupos, superando su posición tradicional (Femenías 2012: 144).

En efecto, en los últimos escritos de Butler vemos aparecer preocupaciones más amplias que la del sexo-género, y esta ampliación de su interés coincide, según Femenías, con el quiebre que supuso para el mundo occidental el atentado a las Torres Gemelas de Nueva York en 2001 (Femenías 2012: 207). A partir de ese momento, los intereses de Butler se amplían hacia la cuestión del multiculturalismo y a lo que ella ha llamado precarious life (vida precaria), la vida amenazada en nuestro mundo actual ${ }^{21}$ : no son solamente las minorías sexuales las que corren peligro, sino también todos los otros "excluidos" de la inteligibilidad humana. Muslip parece pensar algo similar al proponer que en Copi la presencia desmesurada de todos los "excluidos" aparece metaforizada ampliamente por los excluidos de los marcos de inteligibilidad heterosexual de la Modernidad. Copi no era un "pensador" ni un filósofo, y de hecho, no teorizó ni escribió ensayos o artículos donde hablara de su "filosofía", aunque algo puede derivarse de sus ficciones y de sus opiniones aisladas en entrevistas ${ }^{22}$. Se puede aceptar provisoriamente la hipótesis de Muslip y pensar que en Copi esto sucede así, porque hay un aspecto que es determinante en la relación entre sus

\footnotetext{
${ }^{21}$ La obra donde Butler comienza a desarrollar esta idea es Precarious Life. The Powers of Mourning and Violence (2004).

22 De hecho, Daniel Link (2009a) afirma que "Copi ha presentado con extremada claridad su propia filosofía, su radical concepción del mundo (incluido su Dios) como un universo consistente aun cuando toda ley universal (o precisamente por eso) haya sido suspendida, en particular (pero no solo) la de los géneros y las sexualidades" (383). Y, en otro lugar del mismo ensayo: "[la] gracia infinita [de la obra de Copi] a veces nos impide ver la seriedad de sus postulados" (384).
} 
ideas y el mundo, y es el cuerpo, entendido, dice Muslip, como un espacio de mediación, un límite que configura las fronteras entre lo normal y lo abyecto, una "zona de transición entre la subjetividad y el mundo" (Muslip 2007: 72).

El crítico teatral Michel Corvin ha dicho que en el teatro de Copi puede encontrarse una "objetivación de las pulsiones", en la forma de "seres concretos" (Corvin citado por Muslip 2007: 142), como si la afectividad humana se volviera puro teatro. Copi pone los cuerpos en escena, la violencia, el canibalismo, entre otras acciones "borderline", a través de un movimiento orgiástico desenfrenado que no tiene fin. Esto tiene que ver, en parte, con aquello que Muslip observaba acerca de la primacía de la "velocidad" en sus acciones, que parecen fluir en un torrente continuo de gags o, como dice Barbéris, de sketches (Barbéris 2008) que se suceden uno tras otro e, incluso en ocasiones, adoptan la forma de "serpientes que se muerden la cola" como dice la autora en otro lugar (Barbéris 2014: 19). Los sujetos "no-hegemónicos" de Copi podrían pensarse desde los que Butler denomina "cuerpos que no importan"23: cuerpos abyectos.

\subsection{Cuerpos abyectos}

Como ya se ha comentado en la Introducción de esta tesis, el cuerpo aparecía, en los primeros feminismos, como una verdad incuestionable y prediscursiva: en términos de ese feminismo, el sexo equivale al cuerpo y el género constituye la marca cultural que viene a imprimirse sobre él. En ese supuesto, que Butler encuentra en Beauvoir y otras de sus seguidoras, no se puede dejar de observar su carácter tributario de la "metafísica de la sustancia", un resabio ontológico (Femenías 2012: 27) que a lo que lleva es,

\footnotetext{
${ }^{23}$ Tal como la autora lo desarrolla en su obra Bodies that Matter: On the Discursive Limits of "Sex", de 1995.
} 
reflexiona la filósofa norteamericana, a la persistencia de la noción de sujeto tal como lo entendía la Modernidad, sin atacar ese principio ontológico binario que divide a la Humanidad en dos alternativas disyuntas denominadas "macho" y "hembra": en realidad, es la "base dimórfica" (Femenías 2012: 21) la que debe ser cuestionada. Así, Butler cuestiona la misma categoría de "cuerpo". Si bien, como ya dijimos, el pensamiento de Butler evoluciona constantemente, citamos este fragmento de su primer libro donde estas ideas suyas aparecen, Gender Trouble (1990):

La división sexo-género y la categoría de sexo en sí parecen dar por sentada una generalización de "el cuerpo" que existe antes de la obtención de su significación sexuada. Con frecuencia, este "cuerpo" parece ser un medio pasivo que es significado por la inscripción de una fuente cultural percibida como "externa" respecto de él. No obstante, cualquier teoría del cuerpo culturalmente construido debería poner en duda "el cuerpo" por ser un constructo de generalidad dudosa cuando se entiende como pasivo y anterior al discurso (Butler 2007: 254).

Para Butler, el cuerpo en Beauvoir (y también en Sartre) se da como una "facticidad muda" (255). Esto responde a la pervivencia de un dualismo cartesiano mente/cuerpo, pero redefinido como "cultura/naturaleza" (255). Butler tiene muy en cuenta a Michel Foucault, para quien la historia lleva implícita una inscripción cultural del cuerpo (como dice el francés en un ensayo de 1979). El cuerpo siempre está "en estado de sitio", "[... y y, al igual que para Nietzsche, los valores culturales aparecen como consecuencia de una inscripción en el cuerpo, entendido como un medio, de hecho, como una página en blanco; no obstante, para que esta inscripción pueda 
significar, ese medio en sí debe ser destruido" (Foucault citado por Butler 2007: 256). Butler traza una analogía entre el proceso histórico según Foucault y la máquina tatuadora de la colonia penitenciaria de Kafka, que debe destruir los cuerpos para tatuarlos, para "inscribirlos culturalmente" (256).

Esa es la concepción foucaultiana del cuerpo como atravesado por el discurso, pero Butler cuestiona incluso este acercamiento, en el cual el cuerpo aparece como previo al discurso, como una superficie pasiva y natural que los procesos históricos dan forma y definen. Butler reconoce esta idea como sumamente estimulante, aunque hará una lectura distinta de la de Foucault y se planteará analizar cómo el cuerpo está constituido, directamente, por la cultura. En la obra de Mary Douglas de 1973, Purity and Danger: An Analysis of Concepts of Pollution and Taboo, ella encuentra también ese dualismo mente/cuerpo pero lee la idea de que:

[...] lo que conforma el límite del cuerpo nunca es puramente material, pero [...] la superficie, la piel, es significada dentro del sistema por tabúes y transgresiones previos; en realidad, los límites del cuerpo [en el estudio de Douglas] son los límites de lo social per se. Una formulación postestructuralista de su planteamiento bien podría tener en cuenta que los límites del cuerpo son los límites de lo socialmente hegemónico (Butler 2007: 258).

La concepción del cuerpo que Butler toma de Douglas concibe al cuerpo como un modelo regulador, "una sinécdoque del sistema social per se" (260), o bien una materialización de un sistema de tabúes. Así, el cuerpo es un ente en donde los orificios de entrada y salida (de 
alimentación y también de excretación) son controlados para regular la infiltración o la salida de elementos: en ese sentido, el límite entre el "adentro" y el "afuera" del sujeto coincide con el límite que marca el "adentro" y el "afuera" del cuerpo.

Para realizar esa "legislación corporal", se pone en movimiento lo que Julia Kristeva, partiendo del psicoanálisis, ha denominado la abyección: "Lo abyecto nombra lo que ha sido expulsado del cuerpo, evacuado como excremento, literalmente convertido en 'Otro'. Esto se efectúa como una expulsión de elementos ajenos, pero de hecho lo ajeno se establece a través de la expulsión" (Butler 2007: 261). Ahora bien, Butler no deja de señalar que para la escritora y crítica francesa lo abyecto es algo que ha sido expulsado del interior hacia el exterior, pero que en algún momento perteneció a la identidad del sujeto. De modo que en la visión de Kristeva, como en la de Butler (y como en la de Mary Douglas), la abyección es necesaria en tanto mecanismo psicoanalítico pero también social: lo abyecto tiene una función económica de equilibrio en el proceso de "maduración" del individuo, en su entrada al mundo simbólico de la "Ley del Padre".

Los personajes de Copi no son "sujetos hegemónicos" desde el punto de vista social porque en general son sujetos marginales, que conforman aquellos grupos de la sociedad que han sido expulsados de ella, porque sus cuerpos no se adaptan a las normas hegemónicas de funcionamiento social. Como vimos más arriba, predominan figuras transgénero como travestis, transexuales, intersexuales, pero también se encuentran en ella otros sujetos, otros "Otros" marginales, como los inmigrantes africanos, en general practicantes de la homosexualidad (y siempre llamados, estereotípicamente, "Ahmed") o figuras que, aunque no se caractericen como disidentes de la cultura heterosexual, sí implican irrupciones de la 
Otredad en su composición: por ejemplo, el personaje Nicanor Sigampa, personaje de la novela L'internationale argentine, que es negro, y cuya intención es postularse como presidente de la Argentina (es decir, de un país donde no han pervivido habitantes negros), o la rata que, dotada de habla, se convierte en un animal simpático y bueno frente a la maldad de los hombres en La cité des rats: se trata de un reposicionamiento de lo abyectado por la sociedad que vuelve para invertir los lugares, contaminando y rompiendo los límites sociales.

El humor es, como hemos dicho, una dimensión omnipresente en Copi, y se origina en esa visión de caricaturista gráfico que él tenía desde muy joven. La exageración es una de las herramientas del humor, y Copi la utiliza a través de la desmesura de sus acciones. Copi toma las representaciones estereotípicas y las exaspera hasta que pierdan cualquier sentido de identidad esencial. Pone a jugar de maneras diferentes tanto a lo "normal" como a lo "abyecto", y extrema el proceso que determina los límites entre ellos, para forzarlos, violentarlos, y hacer que las fronteras culturales del sujeto se vuelvan porosas.

En algunos de sus personajes, incluso, el límite entre lo interior y lo exterior, entre el sujeto y lo social, entre lo hegemónico y lo abyecto, se traslada a la misma carne del cuerpo; un ejemplo se da con el personaje de Irina en la pieza L'homosexuel ou la difficulté de s'exprimer (1971). En esa obra, el cuerpo de Irina es pensado como una facticidad, a la que el mismo discurso termina por destruir en el proceso de explicarla. A lo largo de la acción, los personajes que rodean a Irina pretenden definirla, poseerla, a través del diálogo, e Irina se queda muda. Como se verá en capítulos posteriores de esta tesis, esta involución del cuerpo de Irina ocurre a partir de esa posesión discursiva que los personajes cercanos a Irina van generando con su intento de saber sobre ella y sobre su cambio de sexo y 
su consecuente identidad de género: "Les questions se concentrent sur les circonstances du changement de sexe d'Irina, dont la parole s'éteint progressivement" (Barbéris 2014: 77). La palabra de Irina se extingue, primero callándose, luego literalmente, al cortarse la lengua: ahora sí es una "facticidad muda" (literalmente), pero no como un estado pre-discursivo, sino como resultado de la acción que el discurso ejerce sobre ella. El discurso que actúa sobre Irina es el de la narrativa transexual del cambio quirúrgico de sexo. Pero, siguiendo a Butler, no es que la cultura (que en este caso sería la narrativa transexual) destruya al cuerpo, o que su violencia se ejerza sobre ella, como en Foucault, sino que sin la cultura ese cuerpo directamente no sería posible, porque no hay cultura sin límite corporal.

En un momento de la obra Irina da a luz a un niño, pero lo expulsa por el ano, y en ese acto el cuerpo entra en crisis, porque se rompe la legislación de la frontera que separa dos de los orificios del cuerpo que funcionan, a su vez, como otras tantas fronteras operatorias del cuerpo:

El límite entre lo interno y lo externo se confunde por los conductos excrementales en que lo interno efectivamente se hace externo, y esta función excretoria se convierte, por así decirlo, en el modelo por el cual se efectúan otras formas de diferenciación de identidades. En efecto, éste es el modo en que los Otros se convierten en mierda [subrayado mío]. Para que los mundos interno y externo sean completamente diferentes, toda la superficie del cuerpo tendría que conseguir una impermeabilidad imposible. Cerrar de esta forma sus superficies sería el límite inconsútil del sujeto; pero ese encierro no podría dejar de explotar precisamente por esa mugre excrementicia a la que teme (Butler 2007: 262). 
En Copi encontramos muerte, podredumbre, antropofagia, pero también, en ocasiones, objetos del máximo refinamiento, como el lamé, las joyas o las habitaciones barrocamente lujosas (Amícola 2000: 67): todo está mezclado, porque los límites corporales/culturales han sido trastocados, y los Otros han traspuesto las fronteras del Sujeto y de la Sociedad, y con ellas las del cuerpo. 


\section{CAPITULO 2 \\ El "mundillo" y el "mundo"}

\subsection{Un cerco de injurias}

Estos sujetos "abyectados" por la sociedad son los protagonistas privilegiados en las ficciones de Copi; especialmente aquellos sujetos de los cuales lo que se abyecta puede localizarse en su incumplimiento de la normatividad sexual, aquella que se ha conceptualizado como "heterosexualidad obligatoria"24. José Amícola (2000) lee la obra de Copi como un producto de la subcultura homosexual, o subcultura gay, aunque luego explique que va más allá de ella. El concepto que utiliza Amícola para llevar a cabo su lectura es el de camp, tomado en un sentido similar al que le da Susan Sontag en sus textos fundacionales sobre el tema (del año 1961), es decir, el de un "[...] amor a lo no natural: al artificio y la exageración" (Sontag 1996: 355): lo camp se definiría como una sensibilidad estética particular que es propia de la comunidad gay, así como lo es el llamado "humour folle" (Amícola 2000: 60):

La fuerza de la estética camp va a surgir, entonces, como estrategia de producción y de recepción -por ejemplo, de los géneros hollywoodenses clásicos-, que reutiliza y transforma la

\footnotetext{
${ }^{24}$ Quizá el análisis más difundido sobre esta "heterosexualidad obligatoria" es el que llevó a cabo la escritora y feminista Adrienne Rich en su texto "Compulsory Heterosexuality and Lesbian Existence", pubicado en 1981, donde observa cómo las sociedades han naturalizado el deseo de las mujeres por los varones, así como los fines puramente reproductivos (Espinosa-Miñoso 2007: 169). Aunque la conceptualización de Rich es la más difundida, el concepto ya había sido propuesto en 1975 por el colectivo Purple September Staff en el artículo "The normative status of heterosexuality" (Espinosa-Miñoso 2007: 168).
} 
cultura de masas. En este sentido, dicho reciclaje implica una crítica de la cultura dominante, pero lo singular del fenómeno es que lo hará en los mismos términos de esa cultura. El camp es, entonces, una forma ideológica llevada a sus extremos que contiene contradicciones en su mayor estado de productividad. El camp se origina, así, en una percepción gay masculina de las imposiciones que la sociedad coloca sobre la sexualidad [...] (Amícola 2000: 52-53).

Lo camp retoma en buena medida todo el lenguaje de la discriminación hacia la homosexualidad, que la mirada de la sociedad define a través de la caricatura injuriosa; esta caricatura es el modo de representación de la homosexualidad al que la cultura heterosexual ha apelado casi por defecto. La institución de la heterosexualidad necesita, para volverse posible, efectuar una abyección constante de su contraparte homosexual.

Cuando hablamos de "caricatura injuriosa", estamos tomando el término de Didier Eribon y su obra Réflexions sur la question gay, de 1999. Efectivamente, Eribon nos dice que "ser" heterosexual, consiste de algún modo en una lucha por negar o excluir constantemente a la homosexualidad (Eribon 1999: 115). El propio título de esta obra de Eribon es un guiño al libro de Sartre Réflexions sur la question juive (1946): tanto los judíos como los homosexuales han compartido, históricamente, esa definición en la que la sociedad los objetiviza como lo más despreciable, haciéndolos objeto, en ese mismo movimiento, de esa caricatura injuriosa.

El citado Eribon complejiza esta lectura con una reflexión sobre el lenguaje que él lleva a cabo a partir de la teoría de la "interpelación" ("interpellation") de Louis Althusser, pero teniendo en cuenta, a su vez, la 
reinterpretación que de ésta hace Judith Butler en su estudio de la "injuria verbal" (o hate speech) ${ }^{25}$. Según lo explica Eribon, la filósofa "[...] s’interroge sur la question de savoir si l'être social des individus n'est pas fondamentalement dépendant de la possibilité d'être l'objet de la parole de l'autre, avant même qu'elle ne soit effectivement exprimée" (88). La "caricatura injuriosa" funciona así del mismo modo que el "lenguaje injurioso", porque "los precede":

Ainsi, les gays vivent dans un monde d'injures. Le langage les entoure, les enserre, les désigne. Le monde les insulte, parle d'eux, de ce qu'ils disent d'eux. Les mots de la vie quotidienne autant que ceux du discours psyquiatrique, politique, juridique, assignent à chacun d'eux et à tous collectivement une place -infériorisée- dans l'ordre social. Mais ce langage les a précédés : le monde d'injures est là avant eux, et s'empare d'eux avant même qu'ils ne puissent savoir ce qu'ils sont (Eribon 1999: 88).

Habría, así, en el lenguaje con el que se habla de los homosexuales, un "pouvoir constitutif et 'insultant'" (Eribon 1999: 88). Lo que hace Butler, explica Eribon, es tomar el lenguaje en el mismo sentido que Althusser le daba a la "ideología", o sea como "interpelación" (interpellation) ${ }^{26}$; Eribon cita textualmente a Althusser cuando dice que "C'est une seule et même chose que l'ideologie et l'interpellation des individus en sujets" (Eribon 1999: 89), y luego continúa:

Par conséquent, puisque l'idéologie précède la naissance des individus qu'elle interpelle, Althusser peut dire que "l'idéologie a

\footnotetext{
${ }^{25}$ Esto lo desarrolla Butler en su libro Excitable Speech. A Politics of the Performative, de 1997.

${ }^{26}$ En el texto "Idéologie et appareils idéologiques d'État (Notes pour une recherche)" de 1970.
} 
toujours-déjà interpellé les individus en sujets" et que les individus, avant même de naître et donc dès leur naissance, sont "toujoursdéjà" des sujets constitués par l'idéologie qui façonne le monde dans lequel ils arrivent (Eribon 1999: 89).

Así, el lenguaje interpela y constituye. Como ve Eribon en Butler, la injuria (en el caso de la homosexualidad, y también del judaísmo) es el mejor ejemplo de esta "interpelación": en realidad, un sujeto "[...] est à la fois "une subjectivité libre, un centre d'initiatives, auteur et responsable de ses actes" (90), y "un être assujetti, soumis à une autorité supérieure, donc dénué de toute liberté, sauf d'accepter librement sa soumission" (90). En esta lectura, entonces, el Sujeto se forma como tal en la medida en que es "sujetado": el término francés subjection significa tanto sujeción como subjetivación. El sujeto homosexual está "sujetado" por esa designación y a la vez es "subjetivado" en inferioridad.

El camp aparece como una mostración exagerada de la homosexualidad, en la que se ridiculizan los códigos de la identidad que incluso los mismos gays han asimilado como parte de su propia definición: por eso no puede negarse que hay una implicación mutua entre discurso homófobo y homosexualidad, en tanto los sujetos homosexuales no pueden escapar de esa injuria que los define, los nombra, o, como decía Eribon, los encierra. Para Amícola, el camp puede considerarse una respuesta a esa "homofobia endocéntrica de los grupos homosexuales" (2000: 60), una "estratagema" para luchar contra ese discurso homófobo ya de por sí interiorizado por los propios homosexuales:

[...] el camp responde -en tanto proceso de combustión- a la propia homofobia endocéntrica de los grupos homosexuales, una 
estratagema en contra de la seriedad épica masculina que Didier Eribon va a denominar humour folle para luchar contra el discurso homófobo, proveniente de cualquier rincón de una sociedad. En este sentido, el camp aparece como el brazo armado de un movimiento de salida del encierro hacia la visibilidad, habiendo entendido que la ocultación ha sido el primer instrumento para el amordazamiento (o el chantaje) contra las conductas de amor intermasculino (Amícola 2000: 60).

Cuando Amícola habla de "la propia homofobia endocéntrica de los grupos homosexuales" se está refiriendo al movimiento que podríamos denominar como "integracionista" dentro de la homosexualidad, o, si se quiere, "normalizador", asociado a los grupos "homófilos" (como el grupo "Arcadie", fundado en 1954 por André Baudry) que se unen buscando el respeto social, a partir de la discreción, oponiéndose a los gays más "afeminados" que para la sociedad serían cuestionables o, más precisamente, patológicos; el grupo Arcadie buscaría la tolerancia, siendo, así, un movimiento políticamente conservador ${ }^{27}$.

Las etiquetas "homosexual" y "heterosexual" habían sido propuestas por Karl Mária Kertbeny, un escritor húngaro, en 1869, para designar determinados tipos de acciones sexuales (Eribon 1999: 409). La categorización subjetiva y también sujeta, fabricando para el individuo una identidad. Según esta teorización sobre el tema, la homosexualidad nacería a partir de una categoría, es decir, que, como vimos más arriba, es el

\footnotetext{
${ }^{27}$ Así lo interpreta Michael Sibalis: "The homophile movement -which disliked the word 'homosexual' for stressing sex rather than love- was predominantly middle-class, conformist and politically and socially conservative. It argued that public hostility to homosexuals resulted largely from their outrageous and promiscuous behavior; homophiles would win the good opinion of the public and the authorities by showing themselves to be discreet, dignified, virtuous and respectable" (Sibalis 2005: 267).
} 
resultado de un intento clasificatorio del siglo XIX. Algo así es lo que dice Daniel Link al referirse a los homosexuales: "[...] en el universo-Copi no hay homosexuales, ese invento desdichado del siglo XIX (y los pocos que hay mueren en La guerra de los putos ${ }^{28}$ ), sino locas. Locas desclasificadas y degeneradas. Locas fuera de todo sistema clasificatorio." (Link 2009a: 385). Pareciera que las pocas veces en que aparecen personajes "gay" en la obra de Copi es para ser ridiculizados.

\subsection{Formas de salida}

En los primeros años de la década de 1970 existió en Francia una corriente de pensamiento, encabezada, entre otros, por Guy Hocquenghem, en la estela dejada por Foucault y también por Gilles Deleuze y Félix Guattari con su L'Anti-CEdipe : Capitalisme et schizophrénie 1 (1972). El libro principal de Hocquenghem es Le désir homosexuel (1972). En él, se atacan las estructuras patriarcales de la sociedad, entre las que el autor incluye el psicoanálisis o el capitalismo; también se ataca la visión patologizante de la homosexualidad. Para Beatriz Preciado en su epílogo al libro de Hocquenghem, éste, junto con la novela de 1973 Le corps lesbien, de Monique Wittig, inaugura por primera vez para la Historia la gramática que se volverá una piedra angular en el movimiento queer posterior. En su epílogo, Preciado analiza la importancia del FHAR como contra-revolución en el seno de la revolución sexual de principios de los setenta:

\footnotetext{
${ }^{28}$ Aquí Link se refiere a La guerre des pédés de Copi, de 1982, que se ha traducido como La guerra de las mariquitas, en la versión de Alberto Cardín para la Editorial Laertes de España en 1983, hasta la más reciente La guerra de las mariconas en la editorial argentina El Cuenco de Plata, de 2015, donde se presenta la traducción de Margarita Martínez, que unos años antes había aparecido en Internet con el título La guerra de los putos, que es el título que elige Link.
} 
Si las lesbianas se ven desplazadas por la construcción de un feminismo hegemónico, los maricas y las travestis son excluidos a su vez dentro de las prácticas y los discursos de extrema izquierda que consideran la "homosexualidad" y las "drogas" como síntomas de decadencia burguesa. La aparición en Francia del FHAR en 1971, en torno a escritores y activistas como Daniel Guérin, JeanLouis Bory, Françoise d'Eaubonne, Guy Hocquenghem, René Schérer o Michel Cressole será la respuesta a esas exclusiones de maricas, lesbianas, transexuales y travestis de los grupos feministas y de izquierda. El FHAR surge de las cenizas homófobas y lesbófobas de Mayo del 68 y del movimiento feminista. Tendrá por objetivo hacer visible la disidencia sexual en el seno de la extrema izquierda; pero también politizar la sexualidad distanciándose del movimiento Arcadie, que hacía de la homosexualidad masculina una tendencia natural $(y$ a menudo secreta, privada y vergonzosa) frente a la que el sujeto homosexual no tiene opción y que sólo demanda ser respetada socialmente [...]. Guy Hocquenghem escribe El deseo homosexual en el FHAR, en ese contexto de resquebrajamiento de los discursos eurocéntricos dominantes, pero también de ruptura con los "buenos homosexuales" de Arcadie y con "las buenas chicas" del feminismo liberal (Preciado 2009: 144-145)

Pero el Copi que escribe en La guerre des pédés es un Copi posterior (es en el año 1982) quien al parecer mira toda esa época con ironía. Cuando Link dice, en la cita del párrafo anterior, que "los pocos [homosexuales] que hay mueren en La guerra de los putos", se refiere a un conjunto de escenas que encontramos en esta novela, donde aparecen los 
putos militantes muriendo literalmente, de una forma violenta ${ }^{29}$. El crítico Ezequiel Lozano, haciendo referencia a la cuestión de la militancia sexual, y tomando la pieza de Copi La tour de la Défense (que es de 1978, es decir, relativamente cercana en el tiempo a La guerre des pédés) dice lo siguiente:

[La tour de la Défense] está más allá de esas discusiones, porque ya las transitó; sus personajes ya las transitaron. Copi está más allá de las locas burguesas, las convierte en juguetes para armar su teatro mediante escenas que se proponen desarmar aquello mismo que identitariamente, en los 70 , recién se está reivindicando. Estocada queer. Copi deconstruye los ideales integracionistas comunitarios y resquebraja las narraciones identitarias estables del género. En abierto cuestionamiento a sus contemporáneos, critica las manifestaciones de la disidencia sexual normativizada en su época. O sea, desestabiliza radicalmente la heteronormatividad dominante y, al mismo tiempo, su contracara: la homonormatividad (Lozano 2015: 212).

${ }^{29}$ El narrador y protagonista Copi entra a su departamento, donde las mariquitas militantes estaban debatiendo cómo actuar ante una amenaza exterior, y los encuentra a todos masacrados: "Je vis pêlemêle les corps des candidats homosexuels du dix-huitième et du sixième arrondissements, d'un journaliste de Libération et un autre de Paris-Match, plus une journaliste de Charlie-Hebdo, tout ça sur mon Chesterfield. Par terre, quelques homes de theâtre gauchistes, morts dans de macabres positions. Sylvia Monfort s'accrochait au cou de Coluche, le mime Marceau était accroché au lustre. Deux dessinateurs humoristiques, Wolinski et Topor, gisaient enlacés dans l'entrée. Mais le vrai carnage s'était produit dans la cuisine. Parmi les célébrités, Michel Foucault gisait sur le carrelage, accroché aux cheveux du coiffeur Alexandre, Daniel Cohn-Bendit était mort en étreignant une serpillière. II y avait au Moniz une dizaine de travelos du Palace et de Madame Arthur, c'étaient les blondes en blouson de cuir, on aurait dit des poupées gonflables. Les autres, je n'ai pas eu le courage d'aller regarder leur visage de près, mais en tout il devait bien y en avoir plus de quarante, quelques-uns dans des postures hallucinantes : Marguerite Duras se trouvait en position de fœtus à l'intérieur de ma grande poubelle ; elle avait du s'y cacher lors de la fusillade" (Copi 1982: 76-77). 
Es esa "homonormatividad" la que Copi rechazará continuamente en sus ficciones, donde el homosexual aparece como una categoría ya dejada de lado. El crítico Nick Rees Roberts, en una semblanza de Copi, lo describe de este modo: "Gay identity based on object choice was secondary to Copi, whose interest was in gender deviance" (Rees Roberts 2005: 299). Cabría preguntarse si la identidad gay basada en el objeto de deseo era "secundaria" para Copi, como dice este crítico, o más bien ridícula e impracticable. En todo caso, lo que predomina en el mundo ficcional de Copi es, es cierto, el desvío de la identidad de género, antes que la construcción de una identidad fija a partir de la ontologización de actos sexuales, algo que describía Foucault en el primer tomo de Historia de la sexualidad y que ya mencionamos más arriba. A partir de "conductas homosexuales" se construye una identidad, una esencia homosexual. En ese movimiento de "ontologización" se confunde la "identidad de género" con la "orientación sexual (homosexual, heterosexual, bisexual)" (Castellanos 2006: 31) ${ }^{30}$.

La obra de Copi que lleva más lejos la desviación de género es, quizás, L'homosexuel ou la difficulté de s'exprimer, obra que ya hemos comentado en el capítulo anterior; en ella asistimos, según Muslip, a "un caso extremo de formas variadas de configuración de los cuerpos" (Muslip 2007: 52). En una casa en medio de una estepa siberiana, dialogan dos

\footnotetext{
30 Según Gabriela Castellanos, la orientación sexual puede ser: heterosexual, homosexual o bisexual (Castellanos 2006: 31). Con respecto a esa "ontologización de actos" que se deriva de los que, en principio, podrían considerarse sólo "actos", dice Castellanos: "Como nos plantea Foucault en el primer volumen de Historia de la sexualidad, hoy se han 'ontologizado' estos términos; es decir, se piensa que un/a homosexual o un/a bisexual es un ser diferente, como si perteneciera a otra especie distinta a la de los heterosexuales, estamos ante lo que se ha llamado la hegemonía heterosexual, que si bien en la cultura occidental siempre ha existido, presenta hoy una forma específica que es producto de la era moderna. Efectivamente, en la premodernidad se concebía la homosexualidad como un acto, no como una entidad; no se la pensaba como algo que imprimiera carácter y convirtiera a quien la ejercía en un ser diferente"
} (Castellanos 2006: 31). 
personajes, uno de ellos es Irina, y la otra es su madre (llamada "Madre", en español en el texto original francés); a ellos se suman otros personajes como una profesora de piano, su esposo, y un médico que en realidad nunca es convocado (aunque se lo nombre) y que se llama Feydeau, es decir, como Georges Feydeau, el autor francés de vaudevilles y farsas de fines del siglo XIX (Wetsel 1994: 117); estos personajes mantienen un diálogo veloz en el que se van develando las verdaderas identidades de los personajes de Irina y "Madre", en una suerte de réplica del estilo del subgénero teatral de la farsa, sólo que aquí esos desenmascaramientos y confusiones identitarias se refieren a la sexualidad. A medida que los diálogos avanzan, vemos que la madre, en el pasado, tuvo una operación en la que se le injertó un pene; luego descubrimos que meses atrás ha dejado embarazada a Irina, su hija; después nos enteramos de que Irina era un hombre al que su madre había obligado a cambiar de sexo en Marruecos. Y el personaje de la profesora de piano, madame Garbo, también se incorpora al conformar un triángulo amoroso con la hija y su madre. En estas configuraciones sexuales atípicas, la identidad de género (masculino, femenino) se ve desvinculada de la identidad sexual "natural" (hombre, mujer), así como también de la "orientación" sexual (homosexual, heterosexual, bisexual). De este modo, estos tres vectores genéricosexuales son dejados sin efecto al ser ridiculizadas las leyes bajo las cuales funcionan. Esta obra pertenece al mismo momento en que Guy Hocquenghem publicaba Le désir homosexuel, el año 1971, año en que, según Rodrigo López (2018), se produce lo que se podría denominar la "revolución homosexual" en Francia ${ }^{31}$. Como ya adelantábamos párrafos

\footnotetext{
31 Según el mismo López, el FHAR se hizo conocido ese año debido a la publicación de un dossier en la revista Tout !, la cual estaba relacionada con un grupo maoísta (López 2018: 27): "Allí se pusieron de relieve tres problemas: la vida cotidiana de los homosexuales, las teorías que pretendían explicarlos y la relación conflictiva de un sector mayoritario de la izquierda francesa con los proyectos de liberación
} 
atrás, en ese libro, Hocquenghem habla de la "polivocidad del deseo" (Hocquenghem 2009: 23), que tanto el sistema capitalista como el discurso psicoanalítico lacaniano intentan controlar: el deseo es organizado alrededor del Falo, y se neutraliza su polivocidad al categorizarlo en heterosexual u homosexual, inventándole, para ello, un origen "natural", y haciendo del Edipo una estructura universal. Para Hocquenghem, la homosexualidad "es una fabricación del mundo normal" (2009: 23). Se trata de una "categoría psico-policíaca" (Hocquenghem 2009: 23) que sirve para encerrar mejor a aquello que señala. Según la cultura heterosexual, el homosexual se equivoca de objeto, ya que se fija en el hombre en vez de en la mujer, que al parecer para el psicoanálisis es el "único objeto sexual social" (Hocquenghem 2009: 53). Por su parte el capitalismo pretende canalizar el deseo sexual hacia un objetivo únicamente reproductivo, es decir, heterosexual. De este modo, "[e]n el mundo de la sexualidad edipizada ya no hay conexión libre de los órganos entre sí, de relación de goce directo" (Hocquenghem 2009: 71). En el deseo polívoco, en cambio, las conexiones no son exclusivas: "Todo es posible en todo momento", dice Hocquenghem, "los órganos se buscan y se enchufan sin conocer la ley de la disyunción exclusiva" (2009: 110). Si leyéramos de un modo literal estas ideas de Hocquenghem, podríamos pensar que es así como se "enchufan" los órganos en esta obra de Copi, siguiendo, de algún modo, ese "flujo polívoco del deseo"; y la familia, esa otra institución reguladora, resulta destruida también; madre e hija no son tales, según se revela en la trama, sino que la madre conoció a Irina, su supuesta hija, en Marruecos, cuando esperaba por su operación de cambio de sexo. $Y$ en esa familia tampoco son posibles la reproducción y la herencia, ya que el hijo que espera Irina es 
abortado, y, como ya comentamos en el primer capítulo, ella expulsa ese hijo por el ano, justamente aquella entrada del cuerpo que en la cultura heterosexual y capitalista es "privatizado", es decir, reservado al ámbito de lo que no se puede representar (Hocquenghem 2009: 72). Copi en una entrevista (publicada en 1979, en inglés, por Jerry Bauer pero traducida luego al italiano) habla sobre la pieza:

L'ho scritta in un momento in cui el movimiento omosessuale di Parigi aveva fatto importante passi avanti. La gala dei gay! Madre e figlia cambiano sesso a Casablanca e vivono in Siberia. Sono interpretate da travestiti. La figlia prende lezioni di pianoforte da una donna che l'ama pazzamente, ma la figlia si dà ai cosacchi in un impeto di passione. La considero una commedia molto moralista sull' abuso della libertà sessuale (Bauer 2008: 184-185, cursivas mías).

¿Qué querrá decir "moralista" para Copi? Resulta difícil dar una respuesta a esto, y también es difícil precisar hasta qué punto Copi no es irónico en la entrevista. Lo interesante es esa mención al momento que se vivía en la época a nivel de los movimientos de militancia sexual.

En la misma entrevista, y seguido de lo anteriormente dicho, Copi agrega que L'homosexuel ou la difficulté de s'exprimer tiene el mismo tono, en ese sentido, que su novela Le bal des folles (Bauer 2008: 185), una novela que fue publicada en 1977, es decir, unos pocos años antes que las obras mencionadas párrafos atrás (La guerre des pédés y La tour de la Défense). En esta novela que, como esas otras dos obras, toma distancia de la época de la "revolución homosexual", se escenifica de manera irrisoria el ambiente gay de París, y también se exploran los tópicos del travestismo, 
la transexualidad y el sadomasoquismo. La homosexualidad aparece nuevamente como una categoría de la que reírse. En el comienzo de la novela, un narrador llamado "Copi" nos cuenta por qué ha decidido convertirse en masoquista:

Voici ce que je vous propose : dans ce roman je serai masochiste. J'aurai découvert ça en 1965, quand j'ai comencé à mener une vie publique homosexuelle après l'avoir longtemps mal cachée. Le masochisme se révéla pour moi comme une homosexualité de plus, ou de rechange. Jusque-là j'avais vécu l'homosexualité comme un vice, rendue publique elle devenait presque une vertu, je me réfugiai dans le masochisme. J'avais une dizaine de partenaires dont un Noir américain, une stripteaseuse, un vieux peintre surréaliste. Ni mes amis homosexuels ni mes amis hétérosexuels ne l'ont jamais su et même en le lisant penseront que c'est une invention tant ils me croient un homosexuel pur. Quand j'ai rencontré Pierre à Rome j'avais des cicatrices infectées dans les mamelles, des brûlures dans les fesses, j'arrivais tout droit de Paris d'une séance trop poussée. D'autres vont chez le psychanalyste. Dans ce sens, ça me guérit, je me sens jeune et gai. (Copi 1999: 23-24)

Ante el peligro de convertirse en un homosexual "virtuoso", el personaje de Copi se pasa al masoquismo, y lo oculta a sus amigos, porque no le creerán, ya que piensan que él es un "homosexual puro". Como en La guerre des pédés, aquí también, entonces, la homosexualidad aparece como categoría endeble, y la "homonormatividad" (para usar el mismo término que usa Ezequiel Lozano) podría pensarse como una reproducción de las 
estructuras opresivas de la heterosexualidad, como se ve en el desorden que se genera en algunas de estas comunidades minoritarias ante la aparición de lo distinto, por ejemplo lo que provoca la llegada de Conceiçao do Mundo en La guerre des pédés, o el comentario del narrador Copi ante la necesidad de ocultar su masoquismo.

Por su parte Copi, en la difundida entrevista con Tcherkaski, ante una pregunta de éste sobre su "mundo imaginario", Copi responde que él no tiene mundo imaginario, y tampoco "mundo homosexual":

[...] no es un mundo homosexual; vos habrás leído, conocerás de mí; son las cosas que tienen más o menos sexualidad, pero si vos leés La vida es un tango, es la historia de un heterosexual más macho que no se puede hablar arriba de la tierra. Yo no me ocupo sólo de los homosexuales, y una novela de antes, que escribí, no es más que de animales; no es de homosexuales ni heterosexuales; para mí son como personajes de Arlequín; si hay dos homosexuales hay dos homosexuales; si los actores pueden actuar de homosexual también pueden hacer de heterosexual, pueden actuar de rata, pueden actuar de mujer también (Tcherkaski 1998: 51-52).

De esta respuesta de Copi se pueden extraer conclusiones: no existe un mundo homosexual, pero tampoco un mundo heterosexual. El protagonista de La vie est un tango es un "macho bien macho", pero también, y por el mismo motivo, bastante ridículo. Porque si los homosexuales son, para Copi, "figuras de Arlequín", tomados desde una teatralidad que exacerba los rasgos de su identidad de género (y también, con ello, sus "roles" de 
género"32), otro tanto puede decirse de las figuras de los heterosexuales, como la del mencionado Silvano Urrutia (el protagonista de La vida es un tango), o también, podemos pensar, en la de Wenceslao de La sombra de Wenceslao. El otro elemento interesante que nos aportan estas palabras de Copi es el de la mención a La cité des rats, al hablar de su novela "sobre animales". Esa novela pertenece precisamente a ese momento tan fructífero de la producción de Copi que es el fin de la década de 1970. En efecto, La cité des rats es de 1979, y de algún modo la revolución y el apocalipsis que sus páginas ponen en escena prefiguran algo de la revolución y el apocalipsis que nos mostrará en 1982 La guerre des pédés. Las ratas son los abyectados que la sociedad expulsa y estigmatiza como su contraparte temida. José Amícola encuentra en estas dos novelas un mutuo diálogo en "código cifrado" (Amícola 2000: 86). Así, Amícola ve como uno de los elementos de más circulación en la obra de Copi

[...] la idea de un sectarismo que se expande hasta absorber toda la sociedad. En tal sentido, son las novelas (y no las obras de teatro) de Copi las que responden a esta intencionalidad. En la expansión de una secta desde lo oculto a lo inmensamente público, parecería que hubiera un desplazamiento freudiano entre el complejo de pertenencia a una minoría degradada y la venganza de lo reprimido, el "retorno de lo reprimido" (Amícola 2000: 86).

Entonces, si bien Amícola había dicho, como vimos, que el camp nace como un gesto dentro del ghetto o de la subcultura gay, también observa que Copi se permite destruir los cercos que limitan ese mundo, expandiendo

32 Con "roles de género" o "estilos de género", se hace referencia a "los modos culturales de actuar y hablar que reconocemos como típicos de uno u otro sexo" (Castellanos 2006: 31). 
lo "reprimido" e invirtiendo los términos a la mejor manera del subgénero satírico. Copi reconoce los límites y las etiquetas clasificatorias, y las usa para romperlas y dar nacimiento a sus figuras ficcionales migrantes y desclasificadas -para usar la misma expresión que usa Link cuando habla de “locas desclasificadas". Después de que en La cité des rats se produzca el desastre apocalíptico, las ratas liberan a los locos de un manicomio, rompiendo así la barrera que divide el "mundo normal" del "anormal". Los locos (igual que "las locas") están fuera-de-sí, fuera de su subjetividad, fuera de su "mundo".

Aunque, el mundo gay, en realidad, es un "mundillo", como dice Aira (1991: 50): "El mundillo gay es la escena que necesita Copi, y Copi es el artista que necesita esta escena para volverse drama, novela, mundo" (50, subrayado mío). En la visión de Aira, Copi construye una especie de "Teatro del Mundo" (51), un conjunto de figuras que le sirven para sus ficciones. Aira también es consciente de que la identidad "homosexual" es una construcción; refiriéndose a L'homosexuel ou la difficulté de s'exprimer, Aira dice que Copi usó en este título dos palabras que no habría usado ni antes ni después: "homosexual" y "expresarse" (Aira 1991: 110). Como hemos visto, esto no es así ya que la palabra "homosexual" aparece en Le bal des folles, y también en La guerre des pédés. Pero de todos modos es importante el señalamiento de Aira, porque advierte qué encierran esas dos palabras para Copi: "El homosexual, es el ser del pasado, de la formación, de la Bildungsroman: nada más ajeno al sistema de Copi. Lo mismo puede decirse de la 'expresión' personal" (Aira 1991: 110). El "homosexual" es la etiqueta médica y patologizante con que se designa al personaje de Irina, a la cual se busca definir todo el tiempo, convirtiéndose, para los otros personajes, en una especie de objeto al que van desintegrando con sus ataques verbales y con las suposiciones que se tejen alrededor de su 
cambio de sexo. No hay una "expresión" posible, porque la expresión está basada en un modelo en el que un ser, una esencia interna, se "expresa", y manifiesta una identidad exterior en concomitancia con su interior "esencial"; y por el contrario en Copi hay un movimiento constante para evitar la identidad, o desarmarla, des-sujetando a los sujetos. Irina es, en realidad, un transexual, dice Aira (110), y por lo tanto su personaje confluye en eso que él mismo llama "transexualidad generalizada"33, algo que para él expresa un continuo, un pasaje constante. No hay un "mundo homosexual" $y$, en todo caso, si lo hubo, Copi lo ha desarmado para construir nuevos "mundos", hacia espacios que se identifican más con "lo trans" que con "lo gay". Pero sobre la noción de trans, y de transexualidad, y de la pertinencia de esa categoría en Copi, se hablará en el siguiente capítulo.

${ }^{33}$ Este concepto propuesto por Aira será abordado en el capítulo siguiente de esta tesis. 


\section{CAPITULO 3 \\ Sujetos en tránsito}

\subsection{Cómo definir lo trans}

Ese sentido que Aira le da a la transexualidad aparece en su libro sobre Copi como un proceso de cambio que afecta a sus personajes. Refiriéndose a la enfermera de la obra Eva Perón, dice Aira: "es la clase de personaje que parece haber dado la vuelta completa de la transexualidad y salir por el otro lado.... Como una mujer, simplemente" (Aira 1991: 106). Así, mediante esa idea de "transexualidad generalizada", Aira expresa esa transformación corporal de los personajes de Copi; páginas atrás, Aira se ha referido al personaje de Pietro, de Le bal des folles, y su devenir corporal, y también a Eva Perón con su travestismo. Aira ve un continuo de transformaciones, la "vuelta completa de la transexualidad", como si se tratase de un tránsito mutador que va confundiendo los rasgos de los sujetos; en el extremo vemos aparecer "una mujer, simplemente".

Según Josefina Fernández, "[t]ransexual es el nombre dado a aquellos/as sujetos/as que solicitan cambio de sexo por encontrar su identificación de género enfrentada a su sexo anatómico" (Fernández 2007a: 322). Se trata de un tipo de transformación que actúa en el nivel corporal, especialmente en los órganos sexuales: se busca modificar el marcador corporal externo para que se adapte a la imagen interna. Así, el transexualismo se opondría al travestismo, que, "[...] en un comienzo nombraba al conjunto de personas que deseaban asumir comportamientos sociales asignados al sexo opuesto" (Fernández 2007a: 322, mi subrayado). Y así, como explica la misma Fernández, al aparecer, durante el siglo XX, la posibilidad del cambio de sexo vehiculizada por las primeras intervenciones 
quirúrgicas, surge la categoría "transexual", "[...] y apareció también el interés por definir sus atributos y características" (322).

En las ficciones de Copi se producen mutaciones de este tipo, y estas en general tienen que ver con las posibilidades quirúrgicas, como se ve en la operación final de Pietro en Le bal des folles, o en la operación de cambio de sexo que sufre María José, el protagonista del cuento "Le travesti et le corbeau" (1983); también hay que pensar en la operación de cambio de sexo a la que ha sido sometida Irina de L'homosexuel ou la difficulté de s'exprimer, la cual es uno de los desencandenantes del avance dramático de la pieza. La operación, la intervención quirúrgica, son presencias habituales del imaginario de Copi.

Resultaría difícil trazar una clasificación de las corporalidades que aparecen en la obra de Copi. Porque sabríamos, en todo momento, que estamos aplicando una especie de filtro que se ha ido elaborando después de décadas de pensamiento y de investigación sobre ese tema, y que tal disociación clasificatoria seguramente no haya existido en la cabeza del autor. Sin embargo, podemos reflexionar sobre algunas de las figuras que aparecen en ella, y medir el alcance que sobre su observación podrían tener las concepciones actuales del género y las identidades sexuales.

\subsection{Transexualidad y travestismo}

En el ejemplo citado más arriba, el del cuento "Le travesti et le corbeau", María José es nombrada como "travesti", pero realiza una operación de cambio de sexo que la convierte en otra persona, pasa de ser hombre a mujer. Aunque el título hable de "travesti", parece tratarse de un caso de transexualidad. En este modelo (y según ciertos ataques que ha recibido) se refuerzan los paradigmas occidentales de género, es decir "masculino/femenino", "hombre/mujer". Por lo tanto la narrativa que la 
identifica es la de "una mujer atrapada en el cuerpo de un hombre", o viceversa. Hay que adaptar ese cuerpo a la identidad (su verdadera "identidad de género") con la cual esa persona se alinea. Entonces, las militancias verán con desconfianza la coerción de ese discurso médico de la transexualidad.

La otra narrativa contra la cual el transexualismo habitualmente era opuesto es, como vimos más arriba, el travestismo. Antes de las primeras operaciones de cambio de sexo en el siglo $\mathrm{XX}$, la narrativa dominante era la del travestismo (Fernández 2007a). Esto fue así hasta 1949, cuando el término apareció por primera vez en la pluma de David Cauldwell (Fernández 2007a: 322) para diferenciar el transexualismo como un síndrome clínico diferente del travestismo ${ }^{34}$-y el término travestismo aplicado a la identidad sexual había sido utilizado por primera vez por Magnus Hirschfeld en la primera parte del siglo XX (Fernández 2004: 39). Una de las primeras comparaciones entre ambos fenómenos se da en las investigaciones de Harry Benjamin, quien, en 1954 "[...] diferencia al travestismo del transexualismo de la siguiente manera: en el travestismo los órganos sexuales son fuente de placer; en el transexualismo son una fuente de disgusto" (Fernández 2007a: 322-323).

Algunos años después, en 1966, se publica The Transsexual Phenomenon, donde Benjamin consolida su postura sobre el transexualismo y establece tres tipos de transexual: no quirúrgico, verdadero de intensidad moderada y verdadero de intensidad alta. A diferencia del primero, más próximo al travestismo, las personas transexuales verdaderas, requieren la cirugía y de manera urgente (Fernández 2007a: 323).

\footnotetext{
${ }^{34}$ Es decir que se diferenciaba "transexualidad" como "desarreglo médico" frente al "travestismo" que no requería intervención quirúrgica (Balza 2009: 245-246).
} 
Así, entonces, hay casos en los que la necesidad de la cirugía no es tan alta, y donde por lo tanto nos encontramos con una persona más cercana al travestismo, ya que la persona en cuestión sólo tiene, según estas definiciones, un problema de índole social (es decir, referido al "rol" de género), y no, como el transexual, un problema relacionado con la "identidad" de género, lo cual lo convertiría en un transexual verdadero, para utilizar las palabras de Benjamin.

\subsection{Transgenerismo}

Hay un término que empezó a cobrar fuerza en los 90, y que vino a criticar, de algún modo, el sesgo de género que informaba o sostenía el paradigma de la transexualidad. Este término es el de "transgénero". Según Mauro Cabral, hay dos acepciones principales del término:

[...] en su versión más restringida, hace referencia a una persona que vive en un género diferente de aquel que le fuera asignado al nacer, pero que no desea modificar quirúrgicamente los marcadores corporales del género (en particular, sus genitales) para conformar estereotipos culturales de corporalidad masculina o femenina, aunque pueda recurrir a métodos quirúrgicos u hormonales de modificación corporal por razones cosméticas, expresivas o de bienestar personal. (Cabral 2007: 325)

A primera vista, parecería difícil usar este término que Copi no hubiera usado, no solamente porque Copi seguramente renegaría de un lenguaje teórico, sino porque el término no tenía el alcance que tiene hoy, y porque aún no había sido popularizado. Según Richard Ekins y Dave King (2006), el término fue utilizado por primera vez por Virginia Prince en la revista 
Transvestia en 1969 (13). Luego Prince lo vuelve a usar en 1978, y allí habla de tres clases de "trans-people": "transvestites, transgenderists and transsexuals" (13): allí define a los transgenderists como un grupo de personas que han adoptado las manifestaciones exteriores del sexo opuesto pero sin intervenciones quirúrgicas: podría decirse que son "male women" (13). Pero, al mismo tiempo, empieza a emerger un sentido diferente, un sentido que Ekins y King Ilaman "umbrella term" ("término paraguas"), es decir, que abarca no solamente a los "transgénero" en sentido estricto, sino también a los/las travestis y transexuales. En la primera formulación del término, hubo dos sentidos privilegiados: "trans" como "transformation" (transformación) y "trans" como "crossing" (atravesamiento, tránsito), y esta fue la situación hasta los primeros años 90. Incluso el término se empezó a usar para reemplazar a "transexual". En estos años 90, el uso ampliado de transgénero se empezó a considerar como un "ir más allá". Así, el transgenerismo supondría "ir más allá" del binarismo genital, ya que no buscaría corregir necesariamente al cuerpo para adaptarlo, sino que a los sujetos que se definen como transgénero les bastaría con realizar modificaciones corporales (como la terapia hormonal, por ejemplo). Así, durante toda la novela Le bal des folles veremos cómo se lleva a cabo el proceso de transformación de Pietro a través de hormonas, vestimentas o maquillajes. Podría decirse que Pierre es, durante gran parte de la acción de la novela, un "transgénero" (respetando el "sentido restringido" de "transgénero") . Pero, a la vez, y teniendo en cuenta el sentido amplio, o "paraguas", la mayoría de los personajes de Copi podrían considerarse "transgénero" porque son, en muchos de los casos, travestis, transexuales, intersexuales. Parece buscarse ir más allá de la "coherencia" que la cultura heterosexual desea o intenta mantener entre la identidad de género, el sexo, la orientación sexual y el rol de género. Cuando un 
transexual alcanza el estatus deseado, deja de ser transexual, porque la transexualidad constituye un camino para llegar al género al que la persona se siente pertenecer. Se es transexual mientras se está circulando ese camino, luego se será mujer u hombre (Mas Grau 2015: 488). En cambio, la transgenericidad es una posición identitaria diferente, que elige el fluir antes que la elección definitiva de un polo o del otro. Muchos transexuales respetan esa idea de "fluidez" que los transgénero defienden, pero a la vez replican que para ellos es necesario poder alcanzar una posición estable para evitar la discriminación y poder mimetizarse con la sociedad.

En estas transformaciones corporales, la "tecnología de género" (tal como la conceptualiza Teresa de Lauretis en 1989) tendrá un papel especial. La de De Lauretis es una concepción de la "tecnología" que no se limita a la construcción de la identidad sexual por las operaciones quirúrgicas, sino que también abarca procesos de transformación relacionados con lo simbólico o lo actitudinal, ampliando así la noción de "materialidad" según Foucault (Fernández 2004: 59) ${ }^{35}$. De este modo, no sólo las identidades y cuerpos contrarios a la heteronormatividad pueden considerarse construidos, sino también aquellos que se consideran categorías "fijas", "naturales", "inmutables", como las de "varón" y "mujer".

\footnotetext{
35 Según lo explica Laura Arnés: "Fue [Teresa de Lauretis] quien, resituando un concepto foucaultiano fundante -el de 'tecnologías del yo'-, propuso el término 'tecnologías del género' para evidenciar que, como la sexualidad, el género tampoco es propiedad natural de los cuerpos sino el conjunto de efectos producidos por complejas tecnologías políticas como el cine, la literatura, la familia, las teorías, las políticas de Estado, las instituciones, etc. Así, el 'género' es para esta autora el producto y el proceso de representación y autorrepresentación de esos modelos jerarquizados de masculinidad y feminidad difundidos por las formas culturales hegemónicas de cada época que todxs repetimos 0 , incluso, de las que nos desviamos (afirmando o negando, siempre se reconoce la norma, que salirse del sistema es imposible). En otras palabras: el género sería -para ella- un sistema de significados predicados e inscriptos sobre la (falaz) dicotomía conceptual de dos sexos biológicos. Pero De Lauretis afortunadamente no se queda ahí: su golpe maestro fue igualar 'género' con 'ideología' (Althusser). Prueben reemplazar los términos: la sustitución funciona cada vez" (Arnés 2014).
} 
En la entrevista famosa con José Tcherkaski, Copi dice que actualmente (en la época de la entrevista, a fines de los 80 ) a nadie se le ocurría vestirse de mujer, solamente a los travestis. "Porque ser mujer", agrega, "es solamente eso, es vestirse de mujer" (Tcherkaski 1998: 50). Tcherkaski le dice que ser mujer "es también tener un par de tetas y una concha”, a lo que Copi responde: “¡Ah! Una concha también tengo yo” (50). Sería difícil determinar a partir de esto si Copi cree, efectivamente, que "ser mujer" es (solamente) "vestirse de mujer": lo que es importante es que los órganos sexuales se convierten, en esta declaración de Copi, en un aspecto prescindible, que puede estar o no, mientras que la vestimenta, el disfraz, implicarían una "tecnología de género", una domesticación dentro de un género determinado, y frente a la cual la genitalidad aparecería, probablemente, como un atributo más.

Resulta imposible no citar aquí ese pasaje de la pieza teatral La tour de la Défense (1978) ${ }^{36}$ : el personaje de la travesti Micheline le pregunta al árabe Ahmed: "Tu me préfères en homme ou en femme ?", a lo que Ahmed responde: "Avec les lunettes en homme, avec la perruque en femme" (Copi 1986b: 196). Daniel Link observa con respecto a este pasaje que "[e]s solo una cuestión de accesorios" (Link 2009a: 383). Si bien para el universo ficcional de Copi las operaciones, las terapias físicas y demás aspectos del imaginario físico-corporal de la sexualidad sean importantes y omnipresentes, esto no implica necesariamente que para él las categorías "hombre" y "mujer" (objetivo de llegada de muchos sujetos trans) tengan una base física fija y que, mucho menos, esté situada en los genitales, por mucho que Copi haga aparecer esta parte de los cuerpos en muchas de sus obras.

\footnotetext{
${ }^{36}$ Fue estrenada recién en 1981.
} 
En el capítulo anterior, nos habíamos detenido en otro comentario del mismo Daniel Link, cuando éste dice que en el universo-Copi no hay homosexuales, sino locas, "locas desclasificadas y de-generadas. Locas fuera de todo sistema clasificatorio". Y Link agrega a eso: "Incluso, como en La torre de la defensa, una verdadera mujer, de esas que te cagan la vida" (Link 2009a: 385). En el episodio al que hace alusión este crítico, un personaje dice: "T'as jamais rencontré une femme de ta vie, toi ? Une vraie femme, de celles qui te font chier jusqu'à la mort ?" (Copi 1986b: 119). Aquí el personaje parece estar tomando un decir de la misoginia propia de los varones. Pero lo que llama la atención, sobre todo, es esa idea de una "verdadera mujer". ¿Qué es una "verdadera mujer" para Copi? ¿Cómo responder a esta pregunta de un modo que no sea esencialista? Justamente esto lo encontramos en la misma obra donde se produce el comentario sobre la peluca o los anteojos como determinantes del "ser mujer". Si "ser mujer es solamente vestirse de mujer", ¿en qué consiste ser una "verdadera mujer"? ¿Los/las travestis como Micheline no podrían ser, en ese sentido, "verdaderas mujeres"?

La misma duda que, en estas épocas, provoca el término "verdadero" aplicado al "ser mujer" es la que provoca, por ejemplo, la clasificación de los transexuales que en su momento llevó a cabo Harry Benjamin, en la que el "transexual verdadero" es el que desea operarse los genitales. En el universo de Copi, si bien, como ya se dijo, el imaginario operatorioquirúrgico está sumamente presente, éste a su vez aparece ridiculizado, y la base física "natural" determinante (para alguien como Tcherkaski, en los ochenta) del "ser mujer" es algo que puede estar mezclado con el resto de los atributos físicos (“Una concha también tengo yo..."). Cuando Link dice que en el mundo de Copi hay solamente "locas" se refiere, como hemos visto en el capítulo anterior, a locas "degeneradas, desclasificadas, fuera del 
sistema”, e incluso, agrega, una (verdadera) mujer: en este comentario de Link, la mujer es una loca más, una subjetividad que, también, podría considerarse "trans" en el universo de Copi.

Justamente Daniel Link da una gran importancia al término ya que afirma (en un comentario que ya hemos utilizado en la Introducción de esta tesis), que Copi "[p]ropone una estética trans, en el sentido en que lo trans debe entenderse, como el pasaje de lo imaginario a lo real" (Link 2009a: 385). Al hablar de ese pasaje "de lo imaginario a lo real", Link está pensando en Moustapha Safouan, autor de un artículo titulado "Contribution à la psychanalyse du transsexualisme" (1974), al que menciona explícitamente en otro texto, donde habla del sexo de Raulito, el personaje de Cachafaz: "No sabemos cuál es el sexo de Raulito: o es una loca o un travesti o un transexual ( $y$ las diferencias son cualitativas: como nos ha enseñado Moustapha Safouan, no se trata de ningún tipo de deslizamiento en línea creciente de 'feminización', sino de un lugar distinto, cada vez)" (Link 2005: 355). Por eso, las posiciones o "lugares" del transexualismo y del travestismo son diferentes; esta idea de Safouan es resumida por Leticia Glocer Fiorini: "[...] Safouan plantea que el transexual acepta la clasificación común hombre/mujer, pero pone en duda el lugar que en ella se le asigna. En cambio, el travesti no acepta la clasificación hombre/mujer y universaliza la posesión del pene, es decir, que para el travesti ambos sexos lo tienen" (Glocer Fiorini 2010: 64), siguiendo, de este modo, "las teorías sexuales infantiles: 'todos los seres tienen pene', y juega sobre los enunciados de la fase fálica que se sostienen sobre la base de que hay un solo sexo, es decir, sobre el mecanismo de la desmentida ${ }^{37}$, la no aceptación de la diferencia"

\footnotetext{
${ }^{37}$ La "desmentida" es el término que Lacan prefiere para la "renegación", la cual es un "[t]érmino utilizado por Freud en un sentido específico: modo de defensa consistente en que el sujeto rehúsa reconocer la realidad de una percepción traumatizante, principalmente la ausencia de pene en la mujer" (Laplanche y Pontalis 2007: 363).
} 
(Glocer Fiorini 2010: 63). Para Safouan, entonces, en una formulación muy conocida que también tomó Severo Sarduy (en La simulación, de 1982), el/la travesti "imaginariza lo real" mientras que el transexual "realiza el imaginario". El/la travesti recrea "el fantasma de la mujer fálica" (Glocer Fiorini 2010: 64), o, en otras palabras, "impone a lo real la forma de su fantasma" (Brum 2010: 7), mientras que el transexual "rechaza lo imaginario consumando en lo real su proyecto" (Brum 2010: 7).

Pero, yendo un poco más allá de las teorías de la transexualidad y del travestismo, y siguiendo un camino de pensamiento similar al de Teresa De Lauretis cuando habla de "tecnologías de género" como algo que va más allá de las operaciones quirúrgicas, el citado Jordi Mas Grau dice, refiriéndose a las estrategias de transformación de personas "transgénero", que ellas "no son exclusivas de las personas trans" (Mas Grau 2015: 491): "La cotidianidad de estas personas no constituía un caso excepcional, sino un caso paradigmático que permitía apreciar con mayor claridad las estrategias que todos nosotros ponemos en marcha para lograr una identidad reconocible" (Mas Grau 2015: 491). Exagerando un poco esa idea de Mas Grau, todos seríamos, de algún modo, sujetos trans. Y entonces, una identidad supuestamente "natural" y "fija" será también, aunque tenga órganos sexuales femeninos (y mal que le pese a Tcherkaski) una identidad trans, en tránsito o más allá de las categorías: parafraseando a Aira, se podía hablar de una "transgenericidad generalizada". Como decía él, la enfermera en Eva Perón, "da la vuelta completa", hasta salir "del otro lado", "como una mujer, simplemente". "Como una mujer", es decir, como una figura trans entre otras. 


\section{CAPITULO 4 \\ Cuerpos en escena}

\subsection{El travestismo como recurso teatral}

En un texto distribuido con motivo de las últimas representaciones de Copi en el teatro Cervantes, ${ }^{38}$ el crítico Hugo Salas dice que, para la puesta en escena original de Eva Perón de 1969, Copi había pensado inicialmente en darle el papel principal al transformista Eugène Couvrit, cuyo nombre artístico era La Grande Eugène (Salas 2017: 17), pero según parece este actor solía ir borracho a los ensayos y no podía aprenderse el guión de memoria (17). Precisamente La Grande Eugène había sido, en palabras del estudioso Laurence Senelick, la "elegante apoteosis" de un movimiento de actores y actrices drag que se estaba dando ubicuamente en Europa desde mediados de la década de 1960, y que en muchas ocasiones consistía en un espectáculo musical en el que el performer hacía lip-sync sobre el escenario (Senelick 1990: 1321). Esa especialidad en lip-sync habría sido otra razón que impedía a Couvrit declamar correctamente las líneas del libreto de Eva Perón (Salas 2017: 17).

Esta anécdota puede ser abordada de diferentes maneras. En un momento histórico donde, tal como dice Senelick, la drag queen estaba tomando el timón de ciertos círculos artísticos (casi como una nueva "fe teatral", dice este crítico), Copi escribe Eva Perón, una obra cuyo personaje central juega, justamente, con ese costado glamoroso que muchas drag queens evocan en su labor actoral. Esta drag glamorosa que evoca el

\footnotetext{
${ }^{38}$ El homosexual o la dificultad de expresarse y Eva Perón, estrenadas conjuntamente en el período de julio a septiembre de 2017, con puesta en escena de Marcial Di Fonzo Bo, en coproducción con Comédie de Caen, Centre Dramatique National de Normandie, Francia.
} 
personaje de Eva es un avatar del travestismo escénico cuyas primeras apariciones se dieron en el siglo XIX, en el ámbito del teatro de variedades. Según Senelick, este "glamorous female impersonator" era o podía ser "[...] a comedian who was dressed and made up to resemble a woman of taste, beauty and chic" (Senelick 1990: 1319). En el siglo XX, esta versión de la drag glamorosa reaparece en los bares y pubs gays, y de ellos habla un famoso libro de Esther Newton sobre el tema39; como dice Senelick: "[...] one of the most successful means of 'passing' with such a public is to give impressions of female super-stars, usually including such gay icons as Mae West, Bette Davis, Tallulah Bankhead, and Judy Garland" (Senelick 1990: 1321). La Eva Perón de Copi produce una sensación ambigua, no solo por tratarse de un/una travesti, sino porque lleva en sí misma la ambigüedad dada por la conjunción entre glamour y vulgaridad.

Este glamour, continúa Senelick, junto con otros clichés del teatro de variedades, fue utilizado por grupos como el de las "drag queens radicales" de Bloolips, fundado en Londres en 1970: esa utilización de los clichés habría sido una forma de poner en escena postulados políticos sobre las concepciones sociales del género (Senelick 1990: 1321). Es decir que la obra de Copi aparece en esa bisagra, en ese momento en que la drag queen glamorosa estaba resurgiendo, pero a la vez articulándose con los nuevos movimientos sociales de fines de los años sesenta, donde esa figura ambigua del travestismo puede empezar a usarse con fines políticos y cuestionadores del "género".

Sin embargo, y como sabemos, el glamour de la Eva Perón de Copi no es solamente el glamour de esos íconos nombrados más arriba, sino que está entramado con las leyendas en torno a Eva Perón como personaje histórico. En Eva Perón, según dice el traductor al español, Jorge

\footnotetext{
${ }^{39}$ El libro se titula Mother Camp: Female Impersonators in America, y fue publicado originalmente en 1972.
} 
Monteleone, encontramos que la lógica del travestismo atraviesa toda la pieza (Monteleone 2000: 14). En efecto, como se verá en el capítulo de esta tesis dedicado a esa obra, hay algo referido al cambio sustitutivo indumentario y cosmético que está en relación con las acciones que conforman el argumento de la pieza. Pero ésta, aunque en su puesta original fue llevada a cabo por un actor varón, puede ser representada también por una actriz, es decir, sin que haya un travestimiento, como se ve en la puesta en escena en que la actriz argentina Alejandra Flechner actuó el papel de Eva Perón en el año $2004^{40}$. La utilización de un actor travestido en Eva Perón es un agregado del director que viene a refrendar y a complejizar el travestismo de la obra de Copi. Hay algo en el personaje mismo que lleva al travestismo, ya que todo el glamour asociado a las iconicidades evocadas por el travestismo aparece combinado, como veremos en el capítulo 6 de esta tesis, con la "leyenda negra" del evitismo (como dice Beatriz Sarlo, 2003: 17), es decir, aquella que la retrata como una arribista, dominante, malhablada: a todo esto, la masculinidad disminuida del personaje de Perón aporta una oposición con ella. La ambigüedad travesti, la convivencia de manifestaciones de dos géneros, es algo que ya está, entonces, en el argumento de la obra.

Por lo demás, los temas referidos a lo que actualmente llamamos las sexualidades y los géneros no aparecen como temas explícitos en la pieza, como sí sucede, en cambio, en su obra inmediatamente posterior, (L'homosexuel ou la difficulté de s'exprimer); de todos modos, hay algo que ya está asomando en esa construcción travesti de los personajes y en la "lógica travesti" de la obra. Posteriormente, en sus unipersonales Loretta Strong (1974) y Le Frigo (1983), Copi representó el papel de sendos

\footnotetext{
${ }^{40}$ Esta actuación se llevó a cabo durante el festival Tintas Frescas, en Buenos Aires. La puesta en escena corrió a cargo de Gabo Correa (Trastoy y Zayas de Lima 2006: 107)
} 
personajes travestis, y en los cuales no se podía escindir, con fines analíticos, al personaje del actor, es decir, que el travestismo escénico no era aquí un agregado del director, sino que ya travestismo formaba parte de la misma lógica de composición del personaje. Los personajes ( $L$. en Le Frigo, y Loretta Strong en Loretta Strong) no están travestidos por decisión del director, sino que la misma pieza supone la construcción de estos personajes como travestis, como si el travestismo fuese su situación básica.

Como se puede ver al leer la historia del teatro antiguo, en aquellas épocas lejanas de los orígenes de este medio artístico, las mujeres no podían actuar; esto se relaciona con la prohibición general de la exhibición de las mujeres en sociedad; hacer actuar a un hombre travestido en mujer era la manera más o menos convencional "[...] to portray women on stage, and was considered far more normal than females playing females. The Greek Theatre, devoted to the cross-dressing god Dionisyus, was virtually transvestite by definition (Senelick 1990: 1315-1316). De manera más extrema, se ha hablado incluso de que "hacer teatro" sería directamente "representar a la mujer", como si ésta fuese la situación teatral básica.

De todos modos, la palabra travestimiento, en el ámbito teatral, evoca un disfraz, aunque no necesariamente un cambio de sexualidad; como dice Patrice Pavis:

El travestimiento no tiene nada de excepcional en el teatro; es incluso la situación fundamental, puesto que el actor juega a ser otro y su personaje, como "en la vida", se presenta a los demás bajo máscaras diversas en función de sus deseos y de sus proyectos. El disfraz es la marca de la teatralidad, del teatro en el teatro y de la mise en abyme del juego (2008: 139). 
Algo similar es lo que dice Claudia Fernández refiriéndose al uso del disfraz en las comedias de Aristófanes, cuando algún personaje se disfraza para engañar a otro, por ejemplo: según ella, el travestimiento es un cambio de identidad en general, no necesariamente un cambio de identidad sexual: "No hay necesidad de decirlo", agrega Fernández, "este tipo de escenas expone lo que es un componente esencial del métier teatral, la investidura del disfraz para impostar una identidad ajena" (Fernández 2010: 83). En la obra Le Frigo, Copi aparece en escena con un traje que es de un lado mujer, del otro hombre, y de otro lado rata ${ }^{41}$ : el cuerpo del personaje ha sido poseído enteramente por el disfraz, pareciera que éste le ha arrebatado la personalidad. Así, entonces, el disfraz en el escenario es, según Fernández, un caso de metateatralidad, porque se sobreteatraliza, se exagera algo ya existente: actuar un papel es estar ya travestido por ese papel: lo que obras como Le Frigo y Loretta Strong llevan a cabo es algo que ya estaba en Eva Perón.

El travestismo, que en las comedias de Aristófanes sirve, entre otras finalidades, para engañar a los personajes, aparece en muchas obras de Copi, y no solamente en el teatro: por ejemplo en La guerre des pédés: Conceiçao do Mundo se presenta primero como una travesti, después se revela como intersexual; paralelamente, su madre Vinicia da Luna revela ser, más tarde, un varón, Vinicio da Luna: estos engaños, de los que los demás personajes son víctimas infantilmente, tienen algo de esas situaciones de disfraz de la comedia antigua que son tratados por Claudia Fernández, y hablan de la importancia que para Copi tiene el vestuario en la conformación de la identidad, como si ponerse el disfraz fuera,

\footnotetext{
${ }^{41} \mathrm{Ha}$ habido diversas puestas en escena de esta obra, y el número de personajes y disfraces que investían al actor han ido variando en número. Así, en una versión del director Gustavo Tambascio de 2017 en Madrid, el actor principal Enrique Viana representó diez personajes diferentes.
} 
inmediatamente, "ser otro", como cuando Copi decía que "ser mujer es vestirse de mujer".

En otro texto del ya citado Senelick, éste se detiene en un comentario del filósofo libertino Restif de la Bretonne (1734-1806) acerca del uso de ropa del sexo opuesto, y comenta: "el rol social primario de la vestimenta, además del cobijo del clima, del frio y del calor, ha sido indicar el género de quien lo porta, y que éste sea discernible a la mirada" (Senelick 2000, mi trad). Por eso el travestismo genera molestia, porque se está contradiciendo un atributo primario del género, constituido por la ropa: casi como si la ropa fuese una extensión de los genitales o de otras marcas que indican el género. Si la transexualidad es, como vimos en el capítulo anterior, la opción de operación de cambio genital que se empezó a difundir como una solución posible para esa contradicción al binarismo que representaban los casos de sujetos intersexuales, puede pensarse que éstos son, como arriesga Isabel Balza, algo así como el "experimento natural [es decir, promovido por la misma Naturaleza] que cuestiona el dimorfismo sexual" (Balza 2009: 246). Los intersexuales serían algo así como la expresión biológica del dualismo que, a nivel del género, se expresa en el travestismo (a partir de la vestimenta y de otros atributos, es decir, de lo escénico).

Todo esto podría limitarse al ámbito teatral, pero Copi hizo aparecer figuras genéricamente inestables no sólo en el teatro, sino también en la narrativa, como por ejemplo la ya mencionada Conceiçao do Mundo, cuya intersexualidad alcanza, para el protagonista, niveles místicos de atracción:

Je voyais en Conceiçao do Mundo tous mes mythes d'enfance réalisés : elle était en même temps Edith Piaf et Mae West, Jack l'Eventreur et un bambin de la Renaissance. Et en plus elle 
m'arrivait de l'Amazonie, une contrée qui se situait naturellement dans ma tête dans le Royaume des Rêves. (Copi 1982: 82-83).

En este comentario del narrador, aparece ligado, entonces, ese ícono tan querido por los travestistas escénicos (Mae West) con el mito del andrógino vehiculizado por la amazona. Sin embargo, en Copi no hay androginia (en el sentido en que puede haberlo en Pubis angelical de Puig, por ejemplo): lo que sí encontramos es la convivencia de ambos géneros, o también el fluir de uno a otro. Esto nos lleva, nuevamente, a Senelick y a los orígenes del teatro, en los cuales el actor aparecía como una instancia "andrógina", casi como un intermediario con lo divino:

The androgynous shaman or berdache who, in primitive cultures, serves an important function as intermediary with the numinous, is considered by some scholars to be sublimated, in civilized societies, into the actor. The shape-changing powers of the shaman include sexual alternation as "celestial spouse", and it has been suggested that fear of this magic resides in the lingering prejudice against the "drag queen". The intermediate between shaman and drag-queen was the performer: the German term Schwuchtel ("queen", "fairy") originally meant a player of comic dame roles [...]. (Senelick 1990: 1314).

Como hemos visto más arriba, el travestismo hombre a mujer era la vía más o menos convencional de representar una mujer en escena, y sobre esto las feministas modernas han argüido, dice Senelick, que "this usurpation of the female role by men was an act of suppression, which allowed a patriarchal society to transmit a false image of Woman" (Senelick 2000). 
En el teatro griego antiguo que analizaba Fernández, en las escenas que implicaban lo que ella llama "travestismos voluntarios", vemos aparecer según esta autora "una manipulación intencional del traje tratado como disfraz" (Fernández 2010: 83). Luego, Fernández agrega que lo que volvía singulares a estas situaciones se encontraba en que ese cambio de ropa se llevaba a cabo de frente ante la mirada de los espectadores (83) Para Fernández estos episodios pueden ser considerados como un caso particular de metateatralidad, "un rasgo típico de la comedia antigua, que hacía del teatro y su maquinaria un espectáculo en sí mismo" (83). Además, se podría encontrar, según Fernández, un grado más avanzado de metateatralidad en los momentos en que el personaje cómico "se disfrazaba de personaje de tragedia" (83).

En efecto, ésta es la misma función que el disfraz tiene en Copi desde su inicio, si pensamos en su primera obra después del gran quiebre de mayo del 68, Eva Perón, donde se juega constantemente con el disfraz (esto lo veremos más ampliamente en el capítulo 6 de esta tesis), hasta el punto de que este disfraz ya forma parte de la lógica de la pieza, como decía Monteleone. Esto es lo que convierte a la pieza en una obra metateatral, como si fuera un "teatro en el teatro". Como veremos en el capítulo siguiente de esta tesis, Copi se permitió jugar con el "teatro en el teatro", de manera explícita (y retorcida) en, por ejemplo, La nuit de madame Lucienne (1985) pero, como nos advierte Patrice Pavis, [para que podamos determinar que estamos en frente de algo que se podría considerar "metateatralidad"]: "No es necesario -a diferencia del teatro en el teatro- que estos elementos teatrales formen una obra dentro de la primera. Basta con que la realidad descrita aparezca como ya teatralizada: es el caso de las obras cuyo tema principal es la metáfora de la vida como teatro" (Pavis 2008: 289). Y continúa: "el metateatro se convierte en una forma de 
antiteatro que difumina la frontera entre la obra y la vida" (289). Ese recordar continuamente la situación de performance es lo que nos indica que estamos en el teatro, y que genera en el espectador las metáforas del "mundo como teatro" asociadas. Disfrazar a Eva, disfrazar a la mucama, constituyen formas de indicar que ya hay algo de teatro en la realidad, que Eva Perón ya porta en sí una teatralidad que la constituye. Recordar la situación de performance en el caso de Eva Perón significa de algún modo recordar que estamos en el teatro.

La frecuente vinculación que de Copi se hace con lo camp es acertada, ya que el espíritu del camp tiene que ver con ese poner entre comillas la realidad, verla como si se tratara de un elemento teatral, es decir, tomar todo como si se tratase de un artificio, en palabras de Susan Sontag. La mujer fantasmática del camp es, según Amícola en un comentario que ya hemos citado, ese objeto que en el camp se busca reproducir (Amícola 2000: 77), y que en Copi es tratado, como todas las demás subjetividades, como algo construido y artificial: esa mujer puede ser Eva Perón, pero también puede ser Loretta Strong, entre otras.

\subsection{El travestismo y la performance/performatividad}

En un artículo correspondiente a un diccionario de términos literarios, en la entrada para el término performance, su autor Henry Sayre nos dice que hay un sentido inicial de performance que es similar al de "representación": "a specific action or set of actions -dramatic, musical, athletic, and so onwhich occurs on a given occasion, in a particular place" (Sayre 1995: 91). Se trata de una representación de un texto preexistente, el cual de algún modo habilita, o más bien autoriza su puesta en escena ante un público: es el sentido del teatro tradicional. Tomado en ese sentido, el texto trasciende la 
representación: la representación es un agregado de un director de escena, pero es autor-izada por el texto literario previo.

Pero, continúa Sayre, desde principios del siglo $\mathrm{XX}$, en especial desde las vanguardias históricas europeas (e iniciando un desarrollo que llega hasta nuestros días) empezó a ganar forma un sentido de performance que la concibe no como un subgénero o derivación del teatro, sino como un género artístico independiente, el performance art, un tipo de espectáculo multimedial (música, pintura, danza, y luego, más contemporáneamente, también video) donde se busca destruir la tradicional oposición teatro-vida o, si se quiere, escena-realidad, teatro-cotidianeidad:

A good way to think of performance is to realise that in it the potentially disruptive forces of the "outside" (what is "outside" the text -the physical space in which it is presented, the other media it might engage or find itself among, the various frames of mind the diverse members of a given audience might bring to it, and, over time, the changing forces of history itself) are encouraged to assert themselves. This is different from traditional performance, in which, for instance, an unruly audience might completely wreck one's enjoyment of a symphony or in which, more subtly, bad acting might ruin Hamlet. It is, instead, upon the dynamics of such intrusions that performance has come to focus its attention (Sayre 1995: 94).

Todo esto tiene una relación grande con el happening, el cual repugnaba a Copi, como veremos en el próximo capítulo, aunque el happening no ha de entenderse necesariamente como performance art: debe reconocerse que tienen en común la idea de que el performer no es un 
actor, que no actúa en el sentido convencional, al igual que los participantes de un happening.

Hay además un tercer sentido de performance que, según Diana Taylor, supera a los anteriores: "performance significaría el proceso mismo de teatralización social, el acto de asumir o re-presentar o atacar un rol proveniente de nuestros limitados repertorios sociales para fines que van más allá de lo estético" (Taylor 1993: 50). Este sentido de performance es el que se encuentra en teorías como la de Erving Goffman, que fue popular en su momento ${ }^{42}$, y que influyó a no pocos estudiosos de las ciencias sociales: "No wonder then that signs of theatricality could be appropriated by any branch of the ambitious theoretical progeniture, gender studies first and foremost", dice Lada Čale Feldman (2000: 9). Según éste, quién empezó primero es difícil de determinar, toda vez que los estudios sobre teatro y las ciencias sociales han estado comprometidas en una "mutua invasión" desde hace varias décadas: "It was only a question of time for the feminist theory of constructionist provenance to respond to that promising call, and that response came in the name of Judith Butler" (Feldman 2000: 9). En un artículo de 1990 titulado "Performative Acts and Gender Constitution: An Essay in Phenomenology and Feminist Theory", Butler toma las teorías de Victor Turner en torno a la noción de performance social y a la repetición de actos que van conformando las identidades ${ }^{43}$; en palabras de Magdalena de Santo comentando la tesis de Butler derivada de este autor: "toda acción se produce dentro del escenario social" (De Santo 2015: 210); y luego, continúa:

\footnotetext{
${ }^{42}$ Se trata del libro The Presentation of Self In Everyday Life, publicado originalmente en 1956.

${ }^{43}$ Se trata del libro The Ritual Process, de 1969.
} 
Cada acción es una "vuelta a presentar", una "reposición" de aquello aprendido, un ejercicio imitativo de los rituales sociales que constituyen la performance entera. De este modo [...] la performance social se construye, si y solo si, a través de la imitación de las prácticas o actos rituales. Si la operación productiva en la matriz de inteligibilidad era la repetición, aquí la autora hace hincapié en la imitación de acciones cuya legitimidad se basa en una re-actuación de y re-experimentación del conjunto de significados heredados. Dado que ninguna acción está movida por alguna exterioridad o trascendencia, en el plano de la acción individual sólo existe una producción y reproducción de los códigos culturales ya establecidos. Nunca mejor dicho, una re-presentación imitativa (De Santo 2015: 210-211).

Por medio de esas repeticiones, según Butler, se interiorizan las identificaciones de género:

[...] actos, gestos y deseo crean el efecto de un núcleo interno o sustancia, pero lo hacen en la superficie del cuerpo, mediante el juego de ausencias significantes que evocan, pero nunca revelan, el principio organizador de la identidad como una causa. Dichos actos, gestos, y realizaciones -por lo general interpretados- son performativos en el sentido de que la esencia o la identidad que pretenden afirmar son invenciones fabricadas y preservadas mediante signos corpóreos y otros medios discursivos. El hecho de que el cuerpo con género sea performativo muestra que no tiene una posición ontológica distinta de los diversos actos que conforman su realidad (Butler 2007: 266). 
Si la esencia y la identidad sexuales son fabricaciones sociales, y que sirven, incluso -en esa formulación de Butler- para poder percibir la base corporal sobre la que se asienta o de la que se deriva la identidad de género, entonces la distinción entre sexo y género a la que se había llegado en la década de 1960 pierde fuerza (Castellanos 2006: 15): el género termina siendo la propia categoría que permite percibir el sexo.

En este contexto, la performance drag aparece para darle a Butler una especie de catalizador, en tanto expresa la forma en que se construyen los géneros; esto le viene a Butler de una pista que encuentra en el libro Mother Camp: Female Impersonators in America (1972) de Esther Newton; así comenta Butler el libro de Newton:

La travestida altera la distinción entre la anatomía del actor y el género que se actúa. Pero, de hecho, estamos ante tres dimensiones contingentes de corporalidad significativa: el sexo anatómico, la identidad de género y la actuación de género. Si la anatomía del actor es en primer lugar diferente del género, y estos dos son diferentes de la actuación del género, entonces ésta muestra una disonancia no sólo entre sexo y actuación, sino entre sexo y género, y entre género y actuación. Del mismo modo que la travestida produce una imagen unificada de la "mujer" (con la que la crítica no suele estar de acuerdo), también muestra el carácter diferente de los elementos de la experiencia de género que erróneamente se han naturalizado como una unidad mediante la ficción reguladora de la coherencia heterosexual. Al imitar el género, la travestida manifiesta de forma implícita la estructura 
imitativa del género en sí, así como su contingencia (Butler 2007: 268-269).

Entonces, la noción de performance aparece en Judith Butler como una piedra angular de su teoría de los géneros pero luego, se irá perfeccionando e, incluso, contradiciendo, en la búsqueda de abarcar no sólo lo teatral, sino también lo lingüístico: "Mi teoría a veces vacila entre entender la performatividad como algo lingüístico y plantearlo como teatral", dice Butler en el Prefacio de 1999 de Gender Trouble. Y así, la idea de lo performativo en relación con performance teatral, se irá refinando hasta convertirse en "performatividad", y estará más bien afincada en lo lingüístico, de la mano de John Austin.

Esta teorización de Butler en torno a Austin es muy conocida por los lectores de esta filósofa. Los enunciados performativos, que Austin estudió como enunciados que sirven para hacer $\operatorname{cosas}^{44}$, cosas que se establecen en el mismo gesto o movimiento en que se dicen, sirven a Butler como un ejemplo de lo que ella considera que es la constitución de los géneros y su asunción por parte de los sujetos. El sujeto actúa las normas de género que preexisten al individuo. Pero Austin, en realidad, había desestimado el teatro como contexto posible del performativo, debido al carácter de repetición de los actos teatrales. La solución viene para Butler de la mano de Jacques Derrida, y de su interpretación de las ideas de Austin que el francés desarrolló en la conferencia de 1974 titulada "Signature, Évenement, Contexte". Es precisamente lo cercano a lo teatral que tienen las identidades de género, su carácter iterable, o sea lo que para Derrida, siguiendo el vocablo sánscrito iter ("otro") significa repetible, lo que

\footnotetext{
${ }^{44}$ Estas ideas fueron expuestas por John Austin en una serie de conferencias de 1955, recogidas luego en un libro, publicado en 1962, y que se tituló How to Do Things with Words.
} 
determinará su consolidación pero también la posibilidad de su desestabilización (de la misma manera en que la posibilidad de repetir una firma aloja, según el filósofo deconstructivista francés, también la posibilidad de su falsificación). Así, Butler redefine la performance teatral de sus inicios “[...] en términos de performatividad lingüística” (Preciado 2001: 80).

\subsubsection{La performatividad como vehículo de lo queer}

Esas ideas de Butler han sido especialmente fecundas para la militancia y el pensamiento en torno a los géneros y las sexualidades, aunque también han recibido críticas:

Si esta línea de análisis ha sido extremadamente productiva especialmente para la generación de estrategias políticas de autodenominación, así como en operaciones de resignificación y reapropiación de la injuria queer, es sin embargo problemática, en cuanto que completa el proceso, ya iniciado en Gender Trouble, de reducción de la identidad a un efecto del discurso, ignorando las formas de incorporación específica que caracterizan distintas inscripciones performativas de la identidad. [...] Durante todo este proceso argumentativo, Butler parece haber puesto entre paréntesis tanto la materialidad de las prácticas de imitación como los efectos de inscripción sobre el cuerpo que acompañan a toda performance (Preciado 2001: 80-81).

La crítica de la que habla Preciado apunta a una supuesta "instrumentalización" de la performance drag por parte de Butler (Preciado 2001: 81); esto ha levantado, según documenta Preciado, las críticas de parte de las comunidades transgénero y transexuales americanas (81), ya 
que Butler "[...] se deshace prematuramente del cuerpo y de la sexualidad haciendo imposible un análisis crítico de los procesos tecnológicos de inscripción que hacen que las perfomances 'pasen' por naturales o no" (81). En resumen, por lo que se deduce de Preciado, podría decirse que se critica un cierto "reductivismo lingüístico" en Butler a partir del cual se niega un origen natural de la materia de los cuerpos sexuados ${ }^{45}$.

Ese uso o instrumentalización política de las drag queens es criticada también por otras voces, como la de Toril Moi, refiriéndose a la contradicción que podemos ver entre ese supuesto carácter subversivo del travestismo escénico y el supuesto carácter superfluo de la distinción entre sexo y género; así resume Gabriela Castellanos la posición de Moi a este respecto:

[...] esa misma distinción [entre sexo y género] que aquí Butler parece abandonar se convierte en base necesaria para su análisis sociocultural y su crítica política, como cuando asevera que los

\footnotetext{
${ }^{45}$ María Luisa Femenías corrige o matiza esta interpretación del cuerpo según Butler: "Se puede sostener que la afirmación butleriana de que el lenguaje construye la materialidad de los cuerpos, no significa que el lenguaje los origina o los causa. Más bien, podría significar que, no puede haber referencia a un cuerpo puro, que no sea al mismo tiempo una construcción lingüística de ese cuerpo. En términos más generales, Butler sugeriría que no es posible referirse a un cuerpo que simplemente está allí, pues el lenguaje constatativo o referencial es siempre y en cierto grado performativo. Es decir que aunque el lenguaje referencial o constatativo parece ofrecer una conexión directa a una realidad extra-lingüística, en verdad depende de una definición semántica previa de las palabras que se utilizan. Por ejemplo, la afirmación Este es un cuerpo de mujer sólo puede ser enunciada por un hablante que tenga algún conocimiento previo de lo que tales palabras significan. El lenguaje referencial o constatativo depende en buena medida de la definición pragmática (previa) de las palabras que se usan y que producen una cierta delimitación previa de lo que se considera 'una realidad extra-lingüística'. La afirmación Este es un cuerpo de mujer, delimita al mismo tiempo la noción de cuerpo y la de mujer con todas las connotaciones del caso. Sólo las posiciones ingenuas o cotidianas piensan que nos referimos a una realidad extra-lingüística 'pura'. En otras palabras, estamos tan acostumbrados al uso referencial de términos tales como cuerpo y mujer que, con frecuencia, no nos damos cuenta de las connotaciones de dichos términos que delimitan e in-forman nuestra visión de esa realidad como extra-lingüística" (Femenías 2012: 124-125).
} 
espectáculos de travestis varones subvierten las normas sociales de género. Pues, continúa diciendo Moi, la misma Butler recalca que cualquier efecto política o socialmente subversivo de estos espectáculos depende del contraste (o disonancia de género) entre los cuerpos masculinos (sexo) y las ropas y conductas femeninas (género). Parecería entonces que, después de todo, la distinción original entre sexo y género de los años 60 es de esencial importancia para la argumentación política de Butler (Castellanos 2006: 26-27).

Por otra parte, el contexto de la performance drag, tal como la que puede hallarse, quizá, en la obra de Copi o en la de las performances drags de esa misma época, tienen la particularidad de situarse en un entorno teatral, estético. En su obra Bodies that Matter (1993), Butler aborda el análisis de la película documental Paris is burning (1990), donde se retrata la comunidad travesti de Nueva York. Según Beatriz Preciado, cuando Butler toma el caso de la travesti Venus Xtravaganza, lo hace "[...] sin tener en cuenta que Venus ha iniciado ya un proceso de transexualización prostética" (Preciado 2001: 81). La noción de "prótesis" en la obra de Beatriz Preciado hace alusión a todos los aparatos y construcciones (incluso discursivas) que amplían o directamente conforman la sexualidad: en este sentido, el paradigma de lo prostésico sería el dildo, como un artefacto que se podría asemejar al "falo" según lo ve $\operatorname{Lacan}^{46}$, y que deconstruye el origen orgánico de la sexualidad ${ }^{47}$. Ese descuido que lleva a Butler a

\footnotetext{
46 La noción de "falo" para Lacan implicaría, según lo explica Susana López Penedo, un desplazamiento "del nivel de la anatomía o 'naturaleza' al nivel del inconsciente o la representación" (López Penedo 2008: 65).

47 "Así, mientras que en un primer momento el dildo parece un sustituto artificial del pene, la operación de corte ya ha puesto en marcha un proceso de deconstrucción del órgano-origen. De la misma manera que
} 
considerar a Venus Xtravaganza como una travesti entre otras, está ignorando su "transincorporación", sus procesos que se dan "en la carne", "en el organismo": el entorno en que se desarrolla la vida de la comunidad transgénero de Paris is burning no es, como el de Copi, un entorno estético. Las prótesis de las comunidades transgénero reales son prótesis que implican procesos reales, que afectan sus vidas, mientras que las prótesis en Copi tienden a parecerse más a prótesis en un sentido teatral, es decir a accesorios teatrales, como decía Daniel Link refiriéndose a aquel pasaje célebre de La tour de la Défense: "es todo una cuestión de accesorios".

\subsubsection{El travestismo como subversión: el teatro queer}

¿Es queer el teatro de Copi? ¿Se puede hablar con ese término de una obra que es bastante anterior a la denominación? En el discurso queer la principal estrategia política consiste en utilizar el discurso de repudio para reivindicarse, así, en y a través del mismo discurso que subjetiva a los sujetos y que por lo tanto los sujeta (tal como lo hemos comentado en el capítulo 2 de esta tesis, al hablar de la "subjetivación" como un proceso de

\footnotetext{
la copia es la condición de posibilidad del original, y que el suplemento solo puede suplir en la medida en que es más real y efectivo que aquello que pretende suplementar, el dildo, aparentemente representante de plástico de un órgano natural, produce retroactivamente el pene originial. Gracias a una pirueta macabra que nos tenía guardada la metafísica, el dildo precede al pene. [...] Tanto si se añade al sexo como si lo sustituye, el dildo como suplemento es exterior, permanece fuera del cuerpo orgánico. El dildo es el alien. Es a la vez y paradójicamente la copia exacta y lo más ajeno al órgano; en este sentido su estatuto no difiere del de la prótesis, que como supo ver Merleau Ponty, compromete todas las premisas de la fenomenología. Como copia, mímesis parásita del pene, siempre está en camino de aproximarse, casa vez más, al ideal de la imitación. Nunca es suficiente. Nunca está bastante cerca del órgano. En realidad, no se basta en sí mismo como imitación del órgano. No se contenta con imitar. Por eso debe transformarse constantemente, autoexcederse de tal manera que va literalmente más allá de la forma, de la talla y de la excelencia de aquello que supuestamente imita. El dildo dirige el pene contra sí mismo" (Preciado 2000: 65-66).
} 
"sujeción"): su misma condición de existencia como seres sexualmente marcados constituye, a la vez, su propia posibilidad de reivindicación. Butler llama a un "acatamiento paródico que cuestione sutilmente la legitimidad del mandato, una repetición de la ley en forma de hipérbole, una rearticulación de la ley contra la autoridad de quien la impone" (Butler 2002: 180). Más allá de las críticas que hemos consignado en el apartado anterior, la importancia y la singularidad que para Butler tiene el travestismo radica, como ya hemos comentado, en que es quien mejor pone a la vista que "la imitación", "está en el corazón mismo del proyecto heterosexual y de sus binarismos de género", y que "no es una imitación secundaria que supone un género anterior y original, sino que la heterosexualidad hegemónica misma es un esfuerzo constante y repetido de imitar sus propias idealizaciones" (Butler 2002: 184). Pero eso no quiere decir que todo travestismo funcione como una "subversión", ya que el mismo "bien puede utilizarse tanto al servicio de la desnaturalización como de la reidealización de las normas heterosexuales hiperbólicas de género" (2002: 184). Este último efecto sería el que se ve en filmes como Tootsie (Sidney Pollack, 1982), o Some Like It Hot (Billy Wilder, 1959) (Butler 2002: 185).

Aquí nuevamente es Lada Čale Feldman uno de los que mejor se acerca al corazón de las observaciones que se le pueden hacer a la consideración del travestismo que hace Butler, utilizando argumentos similares a los de Toril Moi que citábamos en el apartado anterior:

[...] if we were to accept that any gender, transvestite included, is just a performative effect of equal quality of constructedness, the very spectacularity of transvestite subversion would be irretrievably "normalized", unified in a gendered whole and so simply unreadable as a reversal of gender-identification [...]. How can the 
drag appearance result in a denaturalization of the adopted crossgender representation if not through its bodily "basis" somehow contradicting its own gender-performance? And vice-versa: if there is not such a thing as a natural "basis" of which genderperformance is a continuous expression, why would not a "naturalized" gender performance, displaying one-gendered qualities (a "man", or a "woman"), be equally (un)able to draw attention to the constructedness of his/hers gender-identity? (Feldman 2000: 12).

Si todo género está trans-vestido, entonces la potencia de un/una travesti no es tanta, porque el mismo efecto lo puede lograr una "mujer" o un "hombre", desde su propia performatividad. Así como Butler extrae muchas de sus conclusiones de la observación de fenómenos restringidos al ámbito teatral, como la performance drag, del mismo modo nuestro análisis se restringe a la obra de Copi, por lo tanto nos estaremos refiriendo a personajes (hombres, mujeres, travestis, transexuales, intersexuales) que están enmarcados en un contexto de ficción. Para Copi ser mujer es, como hemos visto hasta ahora, vestirse de mujer, siempre que se entienda el "vestido" como un conjunto de "tecnologías de género". Éstas guardan relación con la noción de "género" que sostiene el ya citado Laurence Senelick: "Gender is no longer a disguise that has to be stripped away, but a congeries of actions, statements, appearances, constantly in flux", y, por eso, el travestismo "is simply an appliance to enhance the performativity" (Senelick 2000). Del mismo modo, en Copi, el travestismo aparece, para usar las mismas palabras de Senelick, como un enhancer ("potenciador"), de la performatividad de género, es decir, de la performatividad de género 
propia de Copi, en la cual los "accesorios", y también la "prótesis" son centrales.

Al fin y al cabo, ese carácter de "prótesis" es el mismo que percibió Jorge Lavelli, cuando habló de su dirección escénica de L'homosexuel ou la difficulté de s'exprimer. Lavelli había decidido que, para la puesta en escena de esta obra, todos los personajes femeninos fueran interpretados por hombres. Así dice Lavelli en una entrevista: "La madre y la amiga están representadas por hombres. Pero encarnan mujeres en las que los atributos de la sensualidad, de la sexualidad, están hechos en prótesis; están artificialmente construidos, realizados, imitando muy cerca la realidad. A tal punto que sería como un hiperrealismo" (Tcherkaski 1983: 62).

Este "hiperrealismo" de las prótesis en escena conduce a un "redoblamiento de la representación", como dice Óscar Cornago; según él, "[...] el actor que sube disfrazado de mujer" "no representa el ser-mujer, éste sería un estadio de representación que se encuentra de manera habitual en las mujeres. Los tacones, el vestido, el maquillaje o la peluca se convierten en signos del ser-mujer. En este caso, estos signos se exageran de modo que se haga visible el juego" (Cornago 2006: 11)48. La densidad

\footnotetext{
${ }^{48}$ Para Cornago, entonces, la mujer aparece (en el teatro) como una mascarada, una interpretación que ya estaba en Joan Rivière, cuando hablaba de la "feminidad como máscara" en una conferencia de 1929, y que en parte inspira a Butler a hablar del género desde el punto de vista de la performance en el capítulo 2 de Gender Trouble. Así lo explica Magdalena De Santo: "Rivière retoma los desarrollos teóricos de su maestro Ernest Jones en torno a la sexualidad, con el fin de avanzar y profundizar en nuevas propuestas interpretativas. Si Jones había distinguido a las mujeres homosexuales de las heterosexuales, Rivière reconsidera otro tipo de casos que ella misma define como el caso de mujeres intermedias. Este se basa en los testimonios, que ella misma recogió, de varias mujeres de su tiempo. Mujeres que hacían uso de la palabra y la escritura en público, que mantenían una influyente dedicación a la vida política y que, al mismo tiempo, tenían deseos homosexuales. La feminidad como mascarada es presentada así como un caso clínico (posiblemente autobiográfico), de mujeres heterosexuales y masculinas para su época. [...] La hipótesis central que sostiene Joan Rivière se sintetiza en una paradoja. A saber, las mujeres intermedias desean ocupar un espacio simbólico históricamente masculino pero, al mismo tiempo, temen las consecuencias y el castigo que ello pueda implicar. Entonces, actúan la feminidad, enmascaran su
} 
del atributo teatral pone el evidencia el carácter falsamente "natural" de las identidades de género sexual: la construcción del sujeto "mujer", como ya hemos venido viendo ya es, de por sí, "artificial" o, como diría Preciado, "prostésica" y, por lo tanto, representarla por medio de la exageración del travestismo supone hacer patente esa artificialidad.

En un libro que la escritora Marjorie Garber dedica al travestismo y a su significación en la cultura, incorpora al análisis la cuestión del fetichismo y la "envidia del pene"49. Para Garber el fetichismo es directamente un tipo de representación teatral. Garber se pregunta: "Why is fixation on the penis (and by extension, the phallus) not called a fetish when it is attached to a man? The concept of 'normal' sexuality, that is to say, of heterosexuality, is founded on the naturalizing of the fetish" (Garber 1992: 119) ${ }^{50}$. El teatro representa así, para Garber, una actuación del escenario fetichista, en el que el travestismo deviene un medio idóneo para dejar constancia de esa naturalización que la cultura heterosexual ha hecho del fetiche y sobre la cual está edificada: “Thus Freud's 'penis', the anatomical object, though understood through Lacan's 'phallus', the structuring mark of desire, becomes re-literalized as a stage prop, a detachable object. No one has the phallus" (Garber 1992: 120). Si el teatro fue tan importante en Copi, es porque, a través de él, y por medio de esa "reliteralización" que convierte al

ambición de ocupar el territorio colonizado por la masculinidad y exaltan los clichés del género femenino con el fin de resolver su situación aporética. Estas mujeres interpretan una máscara femenina para ocultar su ansia de reconocimiento público" (De Santo 2015: 207).

49 Según lo explica Susana López Penedo, "Freud definió el fetichismo como la sobrevaloración sexual de una parte del cuerpo u objeto inanimado, y consideraba esta sobrevaloración como una característica del amor masculino" (López Penedo 2008: 65).

50 Para comentar esta cuestión, López Penedo utiliza un argumento de Elizabeth Grosz, en el que ésta critica la visión freudiana del fetichismo: "Grosz afirma que el fetichismo en la mujer supone el establecer el deseo femenino por el falo en el cuerpo del hombre como natural. La heterosexualidad equivale así a la naturaleza. El fetichismo femenino es la norma de la sexualidad humana. Por eso es invisible" (López Penedo 2008: 65). 
falo en un objeto más de la puesta en escena, de la utilería escénica, pudo develar esos procesos subyacentes a la cultura, que en el arte escénico encuentran un lugar de problematización.

El travestismo de Copi es queer en la medida en que funciona como un "potenciador" (en palabras de Senelick) de esa subversión o proceso dislocativo de las identidades sexuales que recorre todas sus obras: el travestismo escénico no es así más que un emergente prácticamente inevitable en su obra; él expresa esa confluencia de tecnologías "prostésicas" de las que fenómenos como la intersexualidad o la transexualidad no son más que sus expresiones biológicas. 


\section{CAPÍTULO 5 \\ El teatro y la "acción"}

"Moi aussi il me faut un déroulement logique, parce que si c'est du happening, je m'en fous ; je vous jette des pétards sur scène à n'importe quel moment" (Copi 1986b: 254).

\subsection{Anti-happening}

Quien habla en el fragmento que se toma como epígrafe para este capítulo es el personaje de un tramoyista dentro de La nuit de madame Lucienne, estrenada en 1985 por Jorge Lavelli en el Festival de Avignon: su frase expresa una opinión conocida de Copi acerca de los happenings. Tal como el autor responde en una entrevista: "Se me ha asociado al happening. El happening, eso me da escalofríos. Es como que alguien entrara aquí y se meara en la botella; es odioso y vacío de historia. El happening es cuando no pasa nada" (Tcherkaski 1998: 124). Ese "vacío de historia" es lo que, según el tramoyista, podría resolverse simplemente arrojando unos petardos "en cualquier momento", es decir que lo que definiría el carácter de acción en el happening sería la indistinción entre las acciones propiamente "teatrales" y aquellas propiamente "reales", ya que las acciones del happening, como dice Alicia Páez en una conferencia de 1966, “[...] conservan su carácter inmediato, concreto, no transfigurado por su incorporación a una 'matriz' que las arrancara de la realidad para volverlas 'imaginarias"' (Páez 1967: 37), mientras que en "[e]l teatro habitual se trata de la diferencia, advertida por el espectador, que media entre el Hamlet, 
encarnado por un actor durante la representación y, por ejemplo, el encargado de acomodar las piezas del decorado al que se ve casualmente deslizarse por un rincón del escenario" (37). En esta obra, en cambio, la decisión de arrojar, inopinadamente, en un momento cualquiera, unos petardos, bastaría para constituir una secuencia de acciones argumentales, ya que en el happening se expondrían "una serie de unidades de acción o situación no conectadas lógicamente" (29). Y eso, para Copi, sería "acción”, pero no "acción teatral", y por lo tanto "vacío de historia".

Esa asociación que según Copi suele hacerse entre él y el happening proviene de sus actividades en el mundo teatral durante la década de 1960. Copi no fue un happenista en sentido estricto, pero tuvo participación en espectáculos teatrales que se acercan a ese género. En esa década, Copi se desempeñaba como dibujante en Le Nouvel Observateur, con La femme assise, y paralelamente realizaba colaboraciones actorales o de guión con algunos teatristas de la época, como por ejemplo la del Grupo de los "Efímeros Pánicos" y sus espectáculos, también asociados al happening. Sin embargo, los creadores de este grupo (Alejandro Jodorowsky, Fernando Arrabal, Roland Topor) negaron la cualidad de happening de sus "efímeros", ya que, a diferencia de aquél y de otros espectáculos "dadaístas", "[...] la provocación estaba más en intenciones y actitudes. En el Pánico, la acción improvisada era acción real", según dice Carmen Crouzeilles (2006: 124). Lo que se trataba de forzar en los "Pánicos" era la "convención teatral", ya que "en los efímeros no se representa, se actúa" (Crouzeilles 2006: 124). Para ilustrar esa "acción" que los Pánicos se ponen como objetivo, Crouzeilles utiliza el ejemplo de un pedazo de bofe que, en el medio de un espectáculo Pánico, fue a impactar en la cara de un crítico teatral que se encontraba entre el público; el proyectil provenía del escenario y, según Crouzeilles, habría allí un "desborde" que ponía en jaque el espacio 
representativo "clásico": "Podríamos decir que el límite se ha debilitado pero no se ha movido, dado que el escenario persiste" (121). Ese escenario "teatral" persiste porque, aunque los Pánicos vayan en contra del teatro clásico, no lo hacen en contra del teatro en sí. En los Pánicos, hay improvisación pero ésta se lleva a cabo en base a una estructura dramática que, aunque mínima, es de raigambre teatral, ya que este movimiento, a diferencia del happening, proviene del teatro, y no, como aquél, de las artes plásticas (Torres Monreal 1986: 32). La manera particular que tiene el Grupo Pánico para interrogar los límites entre arte y vida es esa provocación que, aunque anacrónica, sirve para derogar "el límite convencional entre el espacio de la representación y los espectadores" (Crouzeilles 2006: 121). Así, mientras el happening suponía "la continuación de la pintura en la vida", el Pánico suponía por el contrario "la continuación del teatro en la vida" (Torres Monreal 986: 32), y por eso tuvo tanta importancia en mayo de 1968, como un antecedente artístico que, como veremos unas páginas más adelante, transfería a las masas de estudiantes rebeldes el gesto de la actuación y de la improvisación. Y se trata de improvisación, que es un concepto proveniente del teatro, y no, como en el happening, de indeterminación (Páez 1967: 29) ${ }^{51}$. Podría decirse que el happening y el Pánico buscan efectos similares, es decir, romper esa separación entre público y escena; pero los métodos para lograrlo son diferentes.

\footnotetext{
51 Esto no significa, sin embargo, que el happening carezca de plan. Para Páez, "es preferible usar [el concepto de indeterminación] que por otra parte da lugar a equívocos. El happening no se improvisa, sino que en general es cuidadosamente planeado. La ausencia de ensayos se justifica por el carácter simple de las acciones a ejecutar, por la naturaleza irrepetible de las mismas (cuando se trata de la destrucción total de materiales) y sobre todo porque no se requiere ninguna destreza especial en la ejecución, ni creatividad individual por parte de las personas. La acción es, en cambio, indeterminada, pues dentro de ciertos límites (entradas, salidas, líneas básicas de desarrollo) ella no está rigurosamente pautada" (Páez 1967: 29-30).
} 
Cuando Copi estrena las primeras obras de teatro enteramente salidas de su pluma (después de 1968), el gesto contracultural de la provocación ya no tiene el mismo efecto. A lo largo de su carrera teatral, Copi no parece jugar con esa frontera entre espectáculo y escena. En términos estrictamente teatrales, ese "desborde" que llevaban a cabo los Pánicos, que se traducía en la pretensión arrabaliana de "llevar hasta sus límites la relación escena-sala" (Torres Monreal 1986: 47), no ocurre en Copi. Además, mientras que, como se dijo arriba, en los espectáculos pánicos se improvisaba, Copi ha subrayado que él nunca lo hacía (Tcherkaski 1998: 84), y por eso el texto era tan importante para él. De hecho él siempre dio importancia al hecho de que los realizadores de sus obras (en especial Jorge Lavelli) no cambiaran "ni una coma" de los textos (Tcherkaski 1998: 80).

La obra de la que se extrae el texto del epígrafe corresponde a un momento bastante posterior dentro de la producción de Copi, es una obra tardía. Isabelle Barbéris define a la pieza como: "froid, épuré, cérémoniel" (2014: 109). Por otro lado, según Gustavo Tambascio, esa obra "[...] es Copi oficializado, estrenado por María Casares y Lavelli en Avignon", y la define como "[...] juego infinito del teatro en el teatro, concebido a la manera de una pieza de suspense, [...] es Copi con la mano izquierda jugando a su maestría" (Tambascio 1997: 112). Con la mano izquierda, sugiere Tambascio, quizá porque Copi "oficializado" no sería Copi en estado puro, o quizá porque aquí parece ceder a uno de los tópicos más concurridos por el teatro occidental, el del "teatro en el teatro". Un autor, un tramoyista y una actriz están ensayando una obra teatral una semana antes de estrenarse, en el teatro vacío. La escena que ensayan incluye como parte de las acciones a una rata, que será representada por una especie de títere, que a la actriz no le gusta. El guión de la obra aún no está escrito del todo, así que 
a medida que improvisan, el resultado va siendo incorporado al guión; el grabador que el tramoyista deja funcionando en el escenario registra todo lo que va ocurriendo. En un momento se escucha que madame Lucienne, la encargada de la limpieza del teatro, acaba de llegar para iniciar su turno. Cuando van a pedirle que apague la aspiradora porque el ruido les impide concentrarse, no la encuentran, sólo está la aspiradora andando sola. Empiezan a sospechar que puede ser Vicky Fantômas, una mujer que en un accidente quedó desfigurada, y que está acosando telefónicamente al autor, interrumpiendo el ensayo con sus llamados. De golpe aparece Vicky, ella es quien fabricó la rata. Les cuenta que los ha estado espiando hace bastante tiempo, escondida en el teatro. "Mon regard vous a marqués. Vous avez comencé à répéter votre pièce, à présent vous jouez dans la mienne" (Copi 1986b: 262). Asustados, encuentran un puñal en la boca de la rata. Vicky dice que la rata lo debe haber recogido en algún lugar, y que además es la responsable por la muerte de madame Lucienne, que no aparece. Vicky habla de la rata como si no fuera una marioneta sino que estuviera viva. Se desecha la posibilidad de que la rata sea la asesina porque estaba en el escenario cuando madame Lucienne era asesinada. Como en una novela policial, las culpabilizaciones van pasando por los diversos personajes, primero por la actriz (que en realidad, se revela, es la hija de madame Lucienne), luego Vicky dice que la actriz lo hizo en complicidad con el tramoyista, quien ocultó el cadáver de madame Lucienne. Allí se revela que el tramoyista y Vicky se conocen desde la infancia, y que habían sido "casi novios". El tramoyista le dice a ella que está "montando una escena", y Vicky vuelve a insistir con la culpabilidad de la rata, y el autor vuelve a insistir con que la rata es de goma espuma y que sólo se puede mover con una mano accionándola dentro de ella. La actriz le pregunta a Vicky por qué está empeñada en destruirla, entonces confiesa que ella también es hija de 
madame Lucienne, y que ellas dos son hermanas gemelas. ${ }^{52} \mathrm{El}$ autor le dice a la actriz que se está dejando llevar por el personaje. El tramoyista confiesa que ocultó el cadáver de madame Lucienne, pero explica que no ha visto quién la mató, pensaba que había sido la actriz y él la había querido cubrir. El autor confiesa, finalmente, que es él quien ha matado a madame Lucienne. La actriz toma la pistola de utilería, y el autor le dice que tenga cuidado, que está "realmente cargada". La actriz mata al autor. El tramoyista le dice a la actriz que tienen tiempo para "montar una escena" antes de que llegue la policía. La actriz amenaza con matar al tramoyista, pero éste se adelanta y la mata a ella. En este momento, se advierte que el tramoyista sigue órdenes de Vicky, que le dice que esconda los cuerpos rápido. Vicky le pide al tramoyista que le pase el cuchillo y, cuando se lo pasa, lo apuñala. Alli Vicky pronuncia un discurso y luego se ahorca con la marioneta de rata. $Y$, enseguida, los personajes están vivos nuevamente, y nos damos cuenta de que estábamos en el ensayo de una obra teatral (que contenía, ficcionalmente, el ensayo de otra obra). El autor felicita a todos, han estado muy bien. Hablan sobre la manía del "teatro dentro del teatro". En ese momento llega la mujer de la limpieza, "una verdadera mujer de la limpieza, de carne y hueso". Todos se van y el autor se queda solo, pensando en la obra, y se da cuenta de que en la obra falta la entrada del fantasma de madame Lucienne, al final. De repente ésta entra gritando, dice al autor que está cansada del ensayo, y que ellos están ensayando esa obra para asustarla, ya que ella también se llama "madame Lucienne". Ella encuentra coincidencias entre su vida y la pieza teatral, por ejemplo el hecho de que ella también ha tenido dos hijas gemelas que ha tenido que entregar a la Asistencia Pública. Dice también que hay un complot para asesinarla, ya

52 La gemelidad es uno de los temas de Copi, como puede verse, por ejemplo, en la pieza Les quatte jumelles (1973) 
que una vez un proyector cayó y le pasó cerca de la cabeza, y en otra ocasión alguien puso LSD en su botella de agua. Madame Lucienne saca una pistola y mata al autor. "C'est pas vous, c'est le théâtre que je tue ! (Copi 1986b: 293). La explicación que da madame Lucienne para esa muerte es que el teatro la hizo sufrir desde que era una niña, porque siempre vivió en un teatro: "Parce qu'au théâtre tout est faux! Vos costumes et vos sales gueules c'est du toc, c'est fait pour faire peur aux gens simples comme moi !" (Copi 1986b: 293). Y, en las palabras finales:

Fini le théâtre ! Finies les belles robes et les couronnes de strass, finies les têtes d'affiches et les soubrettes, les faux culs et les faux cils, finis les metteurs en scène, leurs amants et leurs maîtresses, finies les marionnettes syphilitiques, les rideaux rouges et les perruques vertes, finis les drames, les comédies et les tragédies, finis les décors et les découpes ! Le théâtre est fini ! (Copi 1986b: 293).

Así, Copi retoma a su manera el transitado tópico del "teatro en el teatro". Uno de los antecedentes de Copi en este tema pudo haber sido Jean Genet, algo sobre lo que se hablará en el capítulo siguiente. Ese tipo de experimentos de "teatro en el teatro", ese tipo de "sobreteatralización", esa concreción de la metáfora del Theatrum Mundi53, ha servido tradicionalmente para poner en evidencia la situación del "espectador" que mira una escena: "Gracias a esta reduplicación de la teatralidad, el nivel externo adquiere un estatuto de realidad acrecentada: la ilusión de la ilusión se hace realidad" (Pavis 2008: 452). El trabajo conjunto de autor dramático

\footnotetext{
${ }^{53}$ Esta es una "[m]etáfora inventada en la Antigüedad y en la Edad Media, y generalizada por el teatro barroco, que concibe al mundo como un espectáculo escenificado por Dios e interpretado por actores humanos carentes de envergadura" (Pavis 2008: 476).
} 
y director consiste en hacer funcionar la pareja denegación / teatralización en su relación dialéctica, dice Anne Ubersfeld (1989: 38), entendiendo "denegación" en el sentido freudiano en que lo toma la semiología teatral; la escena teatral y su disposición de objetos, actores y acciones "deniegan" la propia realidad material de esos elementos, como si todos los materiales y personas que fuesen colocados arriba del escenario estuviesen antecedidos, por eso mismo, por el signo "menos" (131); en ese sentido, "denegar" equivale a "poner en escena": "[p]ara Freud, el soñador sabe que sueña aun cuando no lo crea o no quiera creerlo. El teatro posee, de igual modo, el estatuto del sueño; se trata de una construcción imaginaria, y el espectador sabe que esta construcción queda radicalmente separada de la esfera cotidiana" (Ubersfeld 1989: 34). Todo medio o material que se utilice escénicamente pasará a convertirse en otra cosa cuando se apaguen las candilejas $^{54}$. Ahora bien, en las obras donde se escenifica la representación de una obra teatral "se desprende una situación receptiva muy compleja que obliga al espectador a tomar conciencia del doble estatuto de los mensajes que recibe $y$, en consecuencia, a remitir a la denegación cuanto pertenece al conjunto del espacio escénico dejando a un lado la zona en que se opera el vuelco producido por la teatralidad" (38), como si la obra-dentro-de-laobra, al ser sustraída del espacio denegado gracias a la teatralización, remitiese a la "realidad" del espectador de la obra, de una forma directa. La ilusión de la ilusión sería, en este sentido, la realidad.

Pero en La nuit de madame Lucienne, la distinción entre teatro y realidad, aunque es problematizada, se recupera en forma material. Porque cuando madame Lucienne mata al teatro lo hace literalmente, porque a ella le desagrada la "falsedad" de ese medio artístico, por eso habla de las

\footnotetext{
54 André Helbo define la denegación como un "sistema de adhesión (que constituye la creencia) al espectáculo en el modo del 'yo sé muy bien que esto no es real pero lo creo como si lo fuese'” (Helbo 2012:
} 196). 
"pelucas", de las "coronas de strass", de las "bocas de fantasía". Matando al autor, ella mata al teatro como maquinaria: “¡No es a usted, es al teatro al que mato!", son sus palabras. Como dice Marcos Rosenzvaig al respecto: "Ella asesina la cosa desnuda desprovista de ilusión: escenografía, vestuarios y falsas narices" (Rosenzvaig 2003: 92). Cuando el Autor se da cuenta de que lo que falta es el regreso de madame Lucienne en forma de fantasma, ésta aparece realmente, siendo, como se decía más atrás, "una verdadera mujer de la limpieza, de carne y hueso", que mata al teatro. La "pistola falsa" con la que la mujer de la limpieza mata al autor, es ahora "pistola verdadera". A tal punto esta concepción del teatro se basa en lo más material de este arte, que al matar al autor se mata directamente ese arte.

Cuando comienza La nuit de madame Lucienne, los personajes aún no tienen lista la obra teatral que están ensayando; en este momento parece predominar la improvisación: "Il n’y a pas de texte ! Ce n'est pas une pièce, c'est un patchwork !" (Copi 1986b: 254), a lo que el tramoyista responde con aquello que se cita en el epígrafe, acerca de la necesidad de un "desarrollo lógico" que, contrariamente al happening, cuyas acciones pueden ser introducidas en cualquier momento, le está faltando a la obra actual. La actriz concluye que, si en la actuación cada uno va a ir "por su lado", ni siquiera sería necesario ensayar: "Si tu joues de ton côté, ce n'est même pas la peine de répéter, moi je vais m'inventer deux ou trois trucs de café-théâtre de mon côté, on se débrouillera ! C'est fini le vrai théâtre ! Plus de texte, plus de métteur en scène, plus de répétitions !" (Copi 1986b: 255). Luego, a medida que continúa el ensayo, los personajes van dejando pistas que sugieren el borramiento de los límites entre teatro y realidad con el que el tópico del "teatro en el teatro" pretende habitualmente jugar: 
Au cinema on tourne un nombre de scènes par jour, puis il arrive un jour où c'est fini, c'est dans une boîte et puis adieu ! Mais au théâtre le spectacle ne commence ni ne finit jamais! Quand on répète on a la impression de jouer, quand on joue on a la impression de répéter, le jour de la dernière c'est comme si ça n'avait jamais existé. Mais ce qu'il y a de plus éprouvant c'est que soi-même on devient théâtral, on a la impression de jouer même pour fumer un joint ! Si au moins je sentais le personage je foncerais, j'attraperais le public ! Mais quel public ? Qu'est-ce que je représente pour eux ? Rien tant que je n'arriverai pas à cerner mon personnage ! II n`y a pas de personnage ! C'est une pièce sans personnage ! Je risque ma carrière ! On va me jeter des tomates ! Et le rat ! II est inmonde ! Je hais ce rat ! (Copi 1986b: 261).

En este fragmento pueden verse no solamente la oposición entre cine y teatro de la que Copi habló en la entrevista con el diario Libération (diciendo: "El cine es un teatro muy imperfecto" en el que "el tiempo está quebrado"55), sino también los juegos con la teatralidad que llevan a que los personajes puedan confundirse con los actores. Pero esta confusión entre teatro y vida difiere de la del happening, donde lo que se busca es negar al teatro: en el happening se tratará de diluir al teatro en la vida misma, quitarle su individualidad artística, sacarlo de su "torre de marfil". La "función irrealizante de la actuación", en el sentido sartreano mediante el que Alicia Páez, en su texto ya citado, diferencia al teatro tradicional del happening ${ }^{56}$,

\footnotetext{
55 Tcherkaski 1998: 126.

56 Según lo explica Páez, para Sartre "[...] la obra es el objeto irreal correlativo de una conciencia que lo confirma a través de un 'analogon' presente. Lo imaginario surge, entonces, cuando la conciencia apunta a un objeto actual en tanto (y sólo en tanto) que representante analógico de un objeto ausente o inexistente.
} 
parece ser lo que predomina aquí, donde los actores demuestran que van siendo poseídos por lo imaginario. Se abandona entonces el "patchwork" del comienzo (y "patchwork" remite, como el happening, al ámbito de la pintura) y se vuelve al teatro.

\subsection{La marioneta viviente}

La teatralidad, para constituirse como proceso, necesita, como uno de sus requisitos, de la mirada del espectador, la cual, como dice Josette Féral, "postulates and creates a distinct, virtual space belonging to the other, from which fiction can emerge" (Féral 2002: 97); cuando en La nuit de madame Lucienne aparece el personaje de Vicky Fantômas, parece sugerirse algo en relación con esa "mirada" que colabora en instituir la teatralidad, sobre todo a partir de algo que este personaje dice y que ha sido citado en el apartado anterior: "Mon regard vous a marqués. Vous avez comencé à répéter votre pièce, à présent vous jouez dans la mienne" (Copi 1986b: 262). Si ella "marca" con su mirada lo que está sucediendo, ello se puede ver en la lógica de novela policial que asume la obra desde ese instante (en el estilo de la novela Ten Little Niggers de Agatha Christie), con los asesinatos sucesivos, hasta la muerte final de ella misma estrangulada por la rata. Ésta, que en un principio es un objeto de utilería teatral, resulta ser, al estar integrada en la obra que supuestamente sostiene Vicky con su mirada, un objeto con vida propia; al integrarse en la matriz que lo vuelve "imaginario" se convierte en una rata de la cual se cree que puede cometer un asesinato, y ya no se habla de este objeto como "marioneta de rata" sino directamente

\footnotetext{
El tipo de existencia del objeto de arte, en el cuadro, la música, la pieza teatral, es el de otros tantos irreales, aprehendidos a través de estas presencias materiales que constituyen los respectivos 'analoga'; y en el caso particular del teatro, la relación propiamente artística con la obra comienza a establecerse sólo cuando el espectador aprehende, a través de las acciones reales de un actor de carne y hueso, las acciones 'irreales' del personaje imaginario" (Páez 1967: 38).
} 
como "la rata". Desde un principio se le da importancia a estos objetos de utilería, no sólo para reforzar el verosímil que corresponde a un ensayo teatral, sino para acentuar esas interferencias entre la escena y la realidad: cuando la actriz está ensayando en el inicio de la obra y, al sonar el teléfono, se desconcierta porque no recuerda esa escena, los demás le dicen que es el teléfono "de verdad" que está sonando. Lo mismo con la "pistola de verdad" y la "pistola falsa". Esos objetos (el teléfono, la rata, la pistola), devienen imaginarios a medida que la obra instala, dentro de sí misma, esos umbrales del teatro-en-el-teatro. En la semiología teatral se denominará "umbral" a aquella etapa que permite el paso de la frontera de la "convención" teatral; esta "convención" instituye una separación entre el universo espectacular y aquello que le es exterior (Helbo 2012: 196 y 198). Isabelle Barbéris hablará específicamente de la marioneta de rata en el universo de Copi (y nosotros también nos acercaremos a ella en el capítulo 7 de esta tesis). En Le Frigo (1983), la rata aparece como una de las posibilidades en la travestización del personaje principal; en esa obra parece haber una continuidad corporal entre el manipulador y la criatura (Barbéris 2014: 124); la rata transviste parcialmente al personaje protagonista (llamado "L."). Esto lo veremos con más profundidad, pero por el momento lo dicho nos alcanza para pensar esa continuidad entre la marioneta y el marionetista que se vinculan, dice Barbéris, con lo que ocurre en esta pieza "fría" de Copi que estamos leyendo: aquí Vicky Fantômas "enfile le rat" ("se calza la rata) y se suicida estrangulándose con ella (Barbéris 2014: 124): en este tipo de gestos, dice Barbéris, es en donde culminan las luchas entre el Yo y los Otros: en palabras textuales de esta autora: "Qui manipule qui ? Qui enfile qui ?” (“¿Quién manipula a quién? ¿Quién calza a quién?”) (124); estas preguntas que la autora se hace 
surgen de ese autoestrangulamiento mediado por la marioneda: esa mediación es para ella un "moteur de ambivalence" $(124)^{57}$.

Como ya se dijo en el capítulo anterior, el disfraz o travestimiento es, citando a Pavis (2008: 139) y a Claudia Fernández (2010: 83), un recurso de "sobreteatralización", ya que supone un redoblamiento de la situación básica teatral, la de la "actuación" de un papel. El disfraz o travestimiento es también, entonces, un "umbral" de teatralidad que encontramos en esta obra atípica de Copi. Ése es también el papel, pues, que el uso de la utilería tiene en la obra; la utilería aparece figurada como una especie de matriz imaginaria que, en las palabras ya citadas de Alicia Páez, activa o pone en marcha la teatralidad: la marioneta es, en este contexto, un objeto que transviste a quien lo use. Según Barbéris, esa ambivalencia que la marioneta vehiculiza se encontraba ya en el único happening propiamente dicho que Copi llevó a cabo en la década de 1960: se trata de Le Cylindre Rose, realizado junto con la artista plástica Nicola L. en el año 1966 en París; Barbéris lo describe en su libro sobre Copi:

Cette performance-installation conçue par Nicola L. avec le groupe de rock anglais Soft machine est en fait une réflexion sur la frontière. Un performeur déclamait un texte de Copi à l'intérieur de la membrane du cylindre : une colonne molle en bâche plastique de deux mètres de haut et d'un mètre de diamètre tendue sur une armature. La "vagine" matérialisait sans doute certaines obsessions de Copi (Barbéris 2014: 54, subrayado mío).

\footnotetext{
57 En un texto sobre L'Uruguayen (1973), la escritora María Negroni alude a "las marionetas frágiles de Kleist", para referirse a la falta de "entidad" de los personajes de Copi (Negroni 2017: 60). También antes, Aira había sugerido la lectura de Über das Marionettentheater (1810) de von Kleist para "ganar perspectiva" en la lectura de Copi (Aira 1991: 98).
} 
En esta instalación-performance de Copi y Nicola L., la cual parece representar, según Barbéris, una especie de "vagina", ya se advertía una reflexión sobre la "frontera", refiriéndose a la frontera de un individuo y su cuerpo físico. A lo largo de la obra de Copi veremos una y otra vez ese cuestionamiento de los límites entre el interior y el exterior de los individuos (un aspecto del que se hablará en el capítulo 7), así como también, como veremos seguidamente aquí abajo, entre "vida" y "muerte".

\section{3. "Actuar" y mayo del 68}

César Aira se refiere a un comentario sobre el teatro que hace Jean Cocteau, según el cual "la diferencia entre el teatro y la vida es que en el teatro los muertos se levantan al final, y en la vida no" (Aira 1991: 117), a lo que luego agrega: "Pero sucede que los muertos en el teatro se levantan en la vida, es decir cuando la representación ha terminado. Copi en cambio los hace levantar dentro del teatro, es decir hace retroceder la vida hasta que queda dentro del teatro, la realidad queda dentro del arte" (117). Sin plegarnos a conclusiones tan generales como la última, el comentario de Aira ayuda a pensar esa característica especial que tiene la muerte en Copi. Los personajes de Copi pueden "resucitar de acuerdo con las necesidades de la trama", según las palabras de Link (2005: 357). El extremo de esto es la acción de Les quattre jumelles (1973), pieza teatral dirigida también por Jorge Lavelli, donde los cuatro personajes mueren y reviven más de quince veces, en un conjunto de series trans-temporales ${ }^{58}$ que se dan en la escena, una detrás de otra. En La nuit de madame Lucienne, las muertes se suceden "en el teatro" y "en la vida", ya que la historia es escandida por esa serie de muertes que puntúan el final de la obra teatral que se está ensayando; cada vez que una representación teatral termina, se vuelve a la

\footnotetext{
${ }^{58}$ El término es de Aira (1991: 113).
} 
vida, pero también al teatro, y así sucesivamente, como corresponde al juego del "teatro en el teatro". La nuit de madame Lucienne podría ser pensada, entonces, como una puesta en abismo del juego constante que en la obra de Copi mantienen entre sí el teatro y la vida ${ }^{59}$.

Casi en el final, un poco antes de que aparezca madame Lucienne, nos enteramos de que varios de los nombres "reales" de los participantes del ensayo son los mismos que tienen los actores que representaron a los personajes en el Festival de Avignon en 1985. La actriz se llama Françoise (como la actriz que hizo de ella, Françoise Brion), y el tramoyista se llama Miloud (como el actor que encarnó su papel, Miloud Khetib) (Copi 1986b: 234). Esa coincidencia onomástica tiende un puente a la realidad, continuando el juego del teatro en el teatro.

Todo esto lo acerca pero a la vez lo distancia de otros ejercicios teatrales como los de Genet o, antes, Pirandello. Mientras los actores se van levantando luego de la muerte del personaje de Vicky, se charla sobre el ensayo, y la actriz se queja: "'Et puis quelle manie que celle du théâtre dans le théâtre ! D'ailleurs ce n'est même pas ça, Pirandello c'est autre chose". (285). Pirandello, en todo caso, como dice Rosenzvaig, "denuncia [...] la inautenticidad" (Rosenzvaig 2003: 119). Aquí en Copi no importa la autenticidad, en todo caso si ella existe dependerá de un conjunto de elementos materiales. Lo que madame Lucienne mata al matar al autor es una concepción del teatro como "lo falso", "lo impostado", "lo exterior", vaciado de toda idea de "verdad", idea que en todo caso dependerá de cuestiones de utilería ("la cosa desnuda desprovista de ilusión", como decía Rosenzvaig en una cita anterior).

\footnotetext{
59 Otro avatar similar dentro de la obra de Copi se da en Une visite inopportune (1988), estrenada en los últimos momentos de vida de Copi, y en la que el protagonista es un dramaturgo que está agonizando en una cama de hospital, enfermo de SIDA, y donde el personaje muere y revive más de una vez, en una serie de juegos de teatro-en-el-teatro.
} 
Cuando los actores, luego del final del ensayo, empiezan a cuestionar al autor en cuanto a ciertas elecciones de la representación, él les contesta: "Vous avez certainement raison mais nous ne sommes pas en mai 68, je ne discute pas de théâtre avec les comédiens" (Copi 1986b: 286). Fue en mayo del 68, nos recordaba el texto de Carmen Crouzeilles, cuando la noción de "improvisación" que podía ser una "herencia" tardía de los primeros espectáculos Pánicos, había transferido su poder estratégico a las masas de estudiantes rebeldes. Crouzeilles menciona un graffiti que apareció en Victoria Station del subterráneo londinense, que decía: "Theatre is dead. Let's act" (Crouzeilles 2006: 125). La conexión entre arte y vida era posible en la medida en que se superase la distancia o separación planteada por el escenario entre actores y espectadores y se pasara a "la acción" (artística y política) (Crouzeilles 2006: 125). Por eso mayo del 68 se vivió, para Crouzeilles, "como una fiesta conjunta entre actores y espectadores" (Crouzeilles 2006).

Cuando Copi da sus primeros pasos en la escritura de textos escénicos (o sea, a fines de la década del 60), esos primeros días "Pánicos" ya han pasado (Crouzeilles 2006: 122), así como el fervor del happening. Las obras de Copi en su período de creación más fecundo no contienen ninguna de este tipo de "provocaciones al público". De aquellos primeros días "pánicos", lo que sigue presente en Copi, sea o no como provocación, es una concepción "monstruosa", que encuentra en la teatralidad su núcleo fundacional: lo monstruoso para los Pánicos "es aquello de lo que no se puede hablar, sólo señalar (ponerlo en la picota), mostrar" (Crouzeilles 2006: 123), rescatando la proximidad semántica entre los vocablos franceses montrer y monstre. De esto se deriva una concepción artística en la que "se invierte el sistema ético-estético tradicional: lo convencionalmente feo, impuro, incoherente tiende a verse en el pánico progresivamente libre de su 
carga negativa para situarse en un plano opuesto que trata de hacer de lo bello, lo puro y lo coherente un sistema de contravalores" (Crouzeilles 2006: 123). Por eso es que para el grupo "Pánico" fueron una gran influencia algunas producciones como la pintura de Goya, los esperpentos de Valle Inclán, así como también "la risa del carnaval renacentista" de Rabelais (Crouzeilles 2006: 122). En esta perspectiva, entonces, el teatro es prácticamente un productor de monstruos, los cuales actúan como un rechazo de "la idealización de la pureza y de otras formas policiales que, a la larga [decían los Pánicos] conducen a la condenación (al exterminio, en el caso de la política) de quienes las practican (Crouzeilles 2006: 123). En Copi la separación entre escena y público es un elemento sumamente importante para la construcción de esa "teatralidad", de esa "mirada" que la conforma.

"Mayo del 68", dice Crouzeilles, "marca el apogeo y al mismo tiempo la destrucción del ideal vanguardista de fusión entre arte y vida" (134). Cuando la experiencia del shock se ha agotado, la sorpresa es absorbida por el mercado. Una provocación como el pedazo de bofe impactando desde el escenario sobre la cara de un espectador no tiene ya el mismo efecto. Copi empieza a estrenar sus mejores obras teatrales después de mayo del 68. Y ahora, en las postrimerías de su carrera, en La nuit de madame Lucienne, una obra del "Copi oficializado, con la mano izquierda, jugando a su maestría", los actores ya no pueden discutir con el autor, ellos ya no tienen el lugar que, como actores, es decir, los que actúan, tenían en mayo del 68. Aquí el autor los maneja, ellos no pueden crear a su antojo. Y como este autor es, según queda de manifiesto en las palabras de la mujer de la limpieza, el mismo teatro (“¡No es a usted, es al teatro al que mato!”), en esta obra esa consigna parece llevarse a cabo, ponerse en escena literalmente por medio de esa muerte que cancela al teatro como "ilusión", 
"mentira", "falsedad". Lo que muere es una idea convencional, casi infantil, de teatro. Como dice Aira, esta obra es: "Io definitivo en el género 'teatro dentro del teatro'", porque en ella "[e]l perspectivismo se hace vertiginoso, infinito, y ni siquiera la aniquilación final lo clausura" (Aira 1991: 121). Es que, a la vez, el teatro está vivo en tanto la mujer de la limpieza, la "de carne y hueso", sea un personaje en un escenario teatral, con un público mirando. En Copi el teatro parece impugnar aquella sentencia escrita en una pared del metro londinense. Como dijimos antes, esa separación entre la escena y el público era fundamental para que Copi pudiera elaborar sus propios monstruos. "Lo que amo", decía, "es ver al público enfrente, podés atravesarlo como en un barco. Uno avanza y el público está siempre enfrente, como una ilusión óptica. Bien en equilibrio" (Tcherkaski 1998: 126). Un equilibrio que no debía romperse para que Copi viera allí “acción”. 


\section{CAPÍTULO 6}

\section{Jean Genet y los vestidos de Eva}

\subsection{Una cuestión de tissus}

Si bien en el texto introductorio que aparece en algunas ediciones de la pieza de Jean Genet Les bonnes (1947) ("Comment jouer Les bonnes") se habla de "las actrices" que debían representar la obra (Genet 1963: 7), y no se expresa ninguna preferencia acerca de que "actores" pudieran asumir el rol de mujeres en escena, ello fue sin embargo lo que se optó por hacer en varias de las puestas de la obra, entre ellas la ya histórica de Sergio Renán en Argentina en 1970, donde los actores Walter Vidarte y Luis Brandoni representaron a las criadas y Héctor Alterio a la Señora (Pelletieri 1993: 79). El motivo que llevó a Renán u otros directores a poner en escena varones haciendo el papel de mujeres se encontraría, según Beatriz Trastoy y Perla Zayas de Lima (2006: 105), en la lectura de un pasaje de una obra narrativa de Jean Genet, Notre-Dame des Fleurs (1944), en el que el narrador se expresa sobre ese recurso: "S'il me fallait représenter une pièce théâtrale, où des femmes auraient un rôle, j'exigerais que ce rôle fût tenu par des adolescents, et j'en avertirais le public, grâce à une pancarte qui resterait clouée à droite ou à gauche des décors durant toute la représentation" (Genet 1986: 253). Es significativo que ese comentario didascálico sobre el travestismo escénico se encuentre precisamente en una de las obras donde más puede verse el trabajo que Genet lleva a cabo sobre la identidad de género como construida y no-esencialista (aunque no use esos términos ni tenga una posición teórica explícita sobre ese asunto). Los jóvenes en escena disfrazados de mujeres, coexistiendo con el cartel a la derecha o a la izquierda del decorado advirtiendo del disfraz, recuerda esa coexistencia 
de elementos masculinos y femeninos que Divine y Notre-Dame, los/las protagonistas de la novela de Genet, mantienen a lo largo de ella. Como sugiere Karen Vandersickel, si el/la travesti muestra que la apariencia y la realidad no pueden ser separados, tampoco podría creerse que debajo de la "apariencia" o "construcción de género" exstiría una "esencia" o "sexualidad" originaria (Vandersickel 2010-2011: 14). Vandersickel discute la insistencia de Sartre en su estudio sobre Genet en sostener que la división entre masculino y femenino es profunda, ya que según esta lectora, para Genet en Notre-Dame-des-Fleurs la división no es más que una cuestión de "tissus" ("telas"), superficial y contingente (16). Lo que Divine y Notre-Dame logran con la teatralización que su travestimiento implica, es decir, la suspensión de la identidad, tiene su equivalente "fenoménico" en la representación teatral soñada por Genet: no solamente disfrazar hombres de mujeres, sino recordar con un cartel que se trata de un disfraz. Así, el recurso elegido por Renán u otros directores para poner en escena Les bonnes hace justicia a ese deseo de travestimiento que Genet expresaba a través de su narrador en Notre-Dame-des-Fleurs.

Precisamente Copi actuará, en 1980, en una versión escénica de Les bonnes en Torino, Italia ${ }^{60}$, y por otro lado Eva Perón se estrenó en 1970, es decir, el mismo año que Las criadas de Renán. En las didascalias de la obra de Copi (que por lo general en sus obras no suelen ser muy abundantes) no hay ninguna explicitación sobre el travestimiento escénico, pero ya se ha dicho, en capítulos anteriores, que se trató de una decisión conjunta de autor y director (Trastoy y Zayas de Lima 2006: 106), y Copi también participó travestido en puestas en escena de otras obras suyas como Loretta Strong (1974) y Le Frigo (1983), donde el travestismo es el punto de partida de construcción del personaje, como se verá en el próximo capítulo.

60 Le serve, estrenada en 1980 en el Teatro Stabile di Torino, dirección de Mario Missiroli, con las interpretaciones de Adriana Asti, Manuela Kustermann y Copi (en el papel de Madame). 
El crítico Ezequiel Lozano, abordando este mismo aspecto en Les bonnes, realiza una comparación con Copi, y cita ese pasaje de La tour de la Défense, que ya hemos mencionado, y a partir del cual Daniel Link concluía que las identidades dependían de los "accesorios"; Lozano lo menciona para hablar de la interrupción del vínculo causal entre sexo y género que encontramos en Copi; en ese vínculo, "a un sexo le corresponde un y sólo un género particular de modo obligatorio y compulsivo" (Lozano 2013: 810), y en él, "los accesorios se usan de acuerdo a la naturaleza" (810). "En cambio, para Copi, teatrista muy cercano al pensamiento de la teoría queer antes de que la misma existiera", opone Lozano, "lo que denominamos naturaleza es una construcción" (810). Esta será la diferencia fundamental entre Genet y Copi a partir de la cual se explorará el uso del travestismo en ambos autores.

Ahora bien, aunque es cierto que en el texto de Genet o en el de Copi el travestismo no está indicado textualmente, también es cierto que, como ya lo han señalado César Aira (1991) o Jorge Monteleone (2000) refiriéndose al caso específico de Eva Perón de Copi, puede verse que el travestismo ya está supuesto en las acciones de la obra. Según Aira, Evita es un/una travesti aun cuando la obra no lo diga explícitamente, porque

su travestismo se sostiene en el sistema mismo: si no es la Santa de los Humildes, la Abanderada de los Trabajadores [...] tampoco necesita ser una mujer. La representación de la mujer es una mentira. Luego, tampoco necesita morir como estaba programado en su mito. Se hace inmortal como imagen (Aira 1991: 107).

No es la Abanderada de los Trabajadores ni la Santa. Ella se salva de morir al colocar, en el lugar de su cadáver, el de la enfermera. El cuerpo de la 
enfermera será el que sostendrá su imagen. Para hacerlo, Evita viste a la enfermera con su ropa, con los vestidos con los que ha insistido a lo largo de toda la pieza, y que se han convertido, dice Beatriz Sarlo (2003), "en una dimensión fundamental del personaje (teatral y político)" (21). Las primeras frases de la obra, pronunciadas por Eva, son conocidas: "Merde. Où est ma robe de presidente ?" (Copi 1986: 91). Pero además, como se decía más arriba, la obsesión de Evita por los vestidos se prolonga a lo largo de la pieza: ella los saca de sus baúles, los desordena, y repetidas veces le ofrece a la enfermera prestarle su vestido de fiesta, como si preparara de antemano ese cadáver que dejará en su reemplazo. En un texto de Karina Vázquez del año 2009, su autora comenta las palabras de Evita en relación con los vestidos que dejará a la enfermera, partiendo de una cita textual de la obra:

"[Eva dirigiéndose a la enfermera] [El vestido] Es el más lindo de todos. Es el mismo que me puse para cenar con Franco, e incluso para ver al Papa. Siempre lo usaba con el visón blanco [...]". El cuerpo de esta Eva no es adicto al clamor del pueblo, sino a las plumas, los colores fuertes, la gala y el glamour espectacular ${ }^{61}$. (Vázquez 2009).

La obsesión con el vestido se ve también cuando describe a su amiga Fanny, a quien en el pasado había nombrado diputada, y dice que le daba placer verla vestida como ella, como un mono, a su lado, en la tribuna oficial (Copi 1986: 123). En la ceremonia que, en Les bonnes, Solange y Claire practican en ausencia de "Madame", puede percibirse también una relación de subordinación a través de los vestidos. Al igual que en Eva Perón con los

${ }^{61}$ Por supuesto, a toda esta construcción del personaje de Eva Perón no es ajeno el hecho de que ella fue actriz en el pasado. 
vestidos de Evita, aquí también, desde el inicio, se habla de los vestidos de "Madame". Ellas entronizan el personaje de "Madame" por medio de un travestismo que no se refiere, como dice María Amparo Olivares Pardo (1995), solamente al uso del vestuario, sino también al del lenguaje: "[...] las criadas adoptan el 'lenguaje' de la Señora, estrategia de 'apropiación' de la identidad del otro. Hay, pues, una subordinación, una interdependencia entre la forma lingüística y la forma de relación social (Olivares Pardo 1995: 240). Y aquí "Madame" también está obsesionada con sus vestidos, varios de los cuales dejará a las criadas: "Rien qu'avec mes anciennes robes vous pourriez être vêtues comme des princesses" (Genet 1963: 61).

En la ceremonia que las criadas Ilevan a cabo, Claire asume el papel de Madame mediante el vestir, pero no solamente usando los "vestidos" propiamente dichos, sino en muchos casos reemplazándolos por otros objetos, como una cortina en la que se envuelve, o un plumero que simula ser un abanico. En esa dirección, la citada Olivares Pardo observaba que el mundo de los objetos en Les bonnes es "indicial y simbólico a la vez"62 (1995: 245): en el caso específico de la indumentaria, ésta refiere al mismo tiempo al otro al que se imita y al status social al que se quiere imitar (245). Como en la obra de Copi, el travestismo ya estaría supuesto, entonces, en

\footnotetext{
62 Según la semiótica teatral, que, según Patrice Pavis, toma el concepto de una tipología propuesta por Charles Peirce en 1978, un indicio "[...] es un signo 'en conexión dinámica (incluida la espacial) con el objeto individual por una parte $\mathrm{y}$, por otra, con los sentidos o la memoria de la persona a la cual sirve de signo' [...]. El índice mantiene una relación de contigüidad con la realidad exterior" (Pavis 2008: 247). Pavis da este ejemplo: "El humo es índice del fuego. Un hombre de andares oscilantes indica, probablemente, que es un marinero. El dedo que apunta hacia alguna cosa es un índice que sirve para designar esa cosa" (Pavis 2008: 247). Y, por otro lado, según el mismo Peirce citado nuevamente por Pavis, "el símbolo es 'un signo que remite al objeto denotado en virtud de una ley, normalmente una asociación de ideas generales, que determina la interpretación del símbolo por referencia a este objeto' [...]." (Pavis 2008: 422); y, [continúa Pavis] "es un signo arbitrariamente elegido para evocar su referente: así, el sistema de los semáforos -colores rojo, verde, ámbar- es utilizado según una convención arbitraria para señalar las prioridades de paso" (422).
} 
Les bonnes, y ya Genet en el texto introductorio indica que "[l]es robes [...] seront extravagantes, ne relevant d'aucune mode, d'aucune époque" (1963: 11), y a esa extravagancia agrega además la monstruosidad: "Il est possible que les deux bonnes déforment, monstruesement, pour leur jeu, les robes de Madame, en ajoutant de fausses traînes, de faux jabots, des seins ou des culs postiches" (1963: 11-12, subrayado mío). Todos esos accesorios conforman una identidad de género que hiperboliza la forma en que se construyen las identidades en la cultura.

Esa deformación monstruosa por medio de la vestimenta y el disfraz, que alude al travestismo, se vincula con la relación que en el mundo de Genet establecen los "sometidos" con los "dominadores"; como apunta Martin Esslin en su libro sobre el teatro del absurdo, lo que las criadas odian "es ver reflejado, la una en la otra, la imagen distorsionada del mundo de los amos, a los que adoran, imitan y odian" (Esslin 1966: 164). Las criadas hacen el papel de la señora, por turno, "expresando así su deseo de ser realmente la señora" (Esslin 1966: 165); por su parte, los amos en Les bonnes,

son una imagen de la sociedad respetable, el mundo cerrado de los justos de los cuales Genet, expósito, se ha sentido excluído, rechazado como un ser monstruoso. La rebelión de las criadas contra sus amos no es un acto social, una acción revolucionaria; sino que está teñida de una cierta nostalgia, de un anhelo [...] (Esslin 1966: 165).

En lecturas como la que traza Esslin en su libro (que tiene mucho en común, aunque también señale sus diferencias, con el libro de Jean-Paul Sartre, Saint-Genet, comédien et martyr, de 1952), el mundo de Genet está 
compuesto por apariencias y reflejos, donde "el ser existe sólo como nostalgia de vida en un mundo de sueño y fantasía" (Esslin 1966: 167). Claire se encarna en el personaje de Madame para, finalmente, morir en ella; esa muerte se produce al final, cuando Claire toma el té de tilo envenenado que ella y su hermana tenían preparado para su ama, y habiendo fracasado en su intento de que la misma lo tomara. El teatro imaginario que se traza Claire tiene el fin ceremonial de colmar los deseos concurrentes de esas dos participantes del ritual, Claire y Solange. Y "lo ceremonial" es importante para Genet porque es aquello del teatro que lo atrae: para él el teatro es "el lugar de la mascarada ceremoniosa" (Brustein 1970: 417), y por eso su teatro tiene al teatro mismo como uno de sus temas principales.

En esa insistencia que hay en el "juego de espejos" (que se extiende al infinito) habría de todos modos una búsqueda "de algo absoluto, de un elemento sagrado en un sistema de valores invertidos, en el cual el mal es el supremo bien [...]" (Esslin 1966: 169). En términos de Didier Eribon, "para Genet escoger el Mal no significa transgredir lo prohibido, sino escoger ser lo que la sociedad ha hecho de él" (Eribon 2004: 54). Se trata, de algún modo, de tomar el papel que la sociedad impone, y llevarlo a los límites. La criada Claire acentúa el sometimiento de su clase social en su encarnación en Madame, la lleva al extremo, actúa como su ama y muere en su lugar. En Eva Perón, en cambio, el sometimiento parecería ser irónico, ya que aquí es la misma Eva, "la Señora", quien da muerte a su enfermera para vestirla como ella y seguir viviendo como imagen (Aira 1991: 107), es ella quien toma la decisión de matar.

El mundo de Genet y el de Copi parecerían ser distintos, según dice Marcos Rosenzvaig (2003), ya que el de Copi es un mundo donde ya no existen los "valores" que en el de Genet sí estaban presentes (114): "Hay 
una fascinación por la mentira en Genet: para que ésta exista es necesaria la presencia de su opuesto (la verdad)" (Rosenzvaig 2003: 117-118). Así, "[c]on todo lo desaforada que la rebelión de Genet pueda parecer, aún requiere la existencia de un sistema tradicional, social, moral y religioso. Para que Genet cometa sacrilegio, debe haber una fe" (Brustein 1970: 416). En Copi pareciera no haber esa fe.

Cuando la Enfermera pasa a convertirse en Eva, cuando su cuerpo pasa a ser el cuerpo que sostiene la imagen inmortal de Evita, la "verdadera" Evita no tiene otra opción que salir de escena. Así, podríamos preguntarnos si Evita es "teatral" porque es un personaje de teatro (es decir: de la obra de teatro de Copi), o si es teatral porque el autor está convocando, en realidad, todo un conjunto de textualidades y relatos que, desde la década de 1950 hasta la actualidad, generaron sospechas o elucubraciones en torno a los funerales de Evita, a la desaparición de su cuerpo, a su embalsamamiento, al supuesto carácter de "puesta en escena" de su culto post mortem; temas sobre los cuales, debe añadirse, hay una ya amplia bibliografía, y sobre la que podría decirse, en resumen, que da cuenta de una visión (tramada por todos aquellos "relatos" que circulaban en la sociedad), que tiende a escindir a Eva Perón en dos mujeres: "Se trata de una mujer que representa el papel de Eva Perón: una personalidad escindida, un cuerpo doble que es, con diferentes nombres, ya Aparato de Estado, ya parte del imaginario popular y, lo que es de capital importancia, una parte no coincide con la otra" (Link 2009a: 430). En realidad, y como ya lo apunta Sarlo en el texto citado, y como adelantásemos en el capítulo 4 de esta tesis, el tema de la pieza de Copi es la "leyenda negra" del evitismo (Sarlo 2003: 17), es decir, de toda una parte de aquellas textualidades y relatos que se encargan de describirla como una arribista, una déspota vulgar (y no con las características de una revolucionaria o una santa), y 
contra quien Perón aparece como un pusilánime. Un comentario de la citada Karina Vázquez condensa esas conclusiones acerca del acento que se ha puesto en el carácter de "puesta en escena" que habría distinguido a los ritos funerarios de Eva, y analiza cómo se ve eso en la obra de Copi; cito extensamente:

Inserto al final de una serie de representaciones literarias de Eva Perón, el texto teatral de Copi se distingue por continuar con la "feroz iconoclasia del topos del cuerpo vivo de Eva" iniciada hacia fines de los sesenta. Siguiendo la alternativa abierta por Manuel Puig, Copi “...instala al final de su obra el sentido de una Eva no muerta, no enferma, sino viva; llena de energía, soberbia e impertinencia justicieras..." [la cita es de un texto de Andrés Avellaneda]. En esta figuración, la coexistencia de prerrogativas burguesas y origen humilde provoca una tensión ideológico-política que cuestiona tanto el mito burgués ("esa mujer"), como el mito peronista ("Evita"): del cadáver falso de Eva se desprende que "esa mujer" en verdad no desaparece, y de su personalidad traidora se deduce que Evita es una invención. Por lo tanto, cabe preguntarse qué es lo que dice esta obra teatral respecto del sustrato ideológico-cultural de la identidad social y política al presentar a una Eva que con su presencia cuestiona ambos imaginarios (Vázquez 2009).

Aquí Evita sobrevive a la muerte pero en su lugar deja otro cuerpo; ella vivirá para ir a disfrutar de sus cuentas de banco en Suiza, con las cuales se insiste repetidamente a lo largo de la pieza. La elección del travestismo escénico resulta entonces, como ya lo indicó Aira, algo prácticamente 
inevitable en una obra que ya habla (a nivel de la "anécdota", al menos) de la teatralidad y del travestismo en la figura de Eva Perón.

\subsection{Sobre-vivir}

Esa especie de "sobrevida" que permiten las imágenes aparece también en otra obra de Genet, Le balcon (1955). Aquí, como en Eva Perón, la "sobrevida" se da en relación dialéctica con la muerte. La acción se desarrolla en un burdel donde las personas "comunes" van a vivir sus fantasías de poder: así las figuras o imágenes en que ellos se encarnan son el Obispo, el General o el Juez. También aquí está la teatralidad, ya que las fantasías que se cumplen en el burdel están organizadas escénicamente por la patrona, Madame Irma. Y los personajes están más preocupados por lo que les pasa a las imágenes antes que a ellos mismos. $Y$ mientras, en el espacio extraescénico, se desarrolla una Revolución donde los rebeldes que la encabezan están empeñados en destruir esas imágenes, que representan, para ellos, a los poderes mismos de la Iglesia, el Ejército y la Justicia. Los rebeldes aparecen como la "vida" que se opone a esas imágenes muertas del poder. Esa es la manera que elige Genet para interrogar la oposición entre "apariencia" y "realidad". Al igual que en Eva Perón, hay un juego espacial entre lo que se muestra en escena (los entretelones del poder) y el Pueblo esperando afuera, en el espacio extraescénico, ansioso por la salud de Evita; con la diferencia de que en la obra de Genet se escenifica, también, al pueblo y a su Revolución: en Eva Perón la acción se mantiene en las habitaciones de Eva, aunque se sepa que el pueblo espera, afuera, que Evita salga a ese otro balcón, el balcón presidencial.

Para llegar a encarnar las imágenes del poder, los clientes del burdel de Genet deben portar toda la utilería teatral que se les dispensa en esa 
casa de ilusiones; esa utilería es la que las imágenes necesitan para ejercer su función (y por lo tanto, para adquirir su identidad), así por ejemplo sucede con la mitra para el Obispo: "Tú, mitra, en forma de bonete de obispo, no te olvides que si mis ojos se cierran por última vez, lo que veré detrás de mis párpados serás tú, mi bonito sombrero dorado... Sois vosotros, lindos adornos, capas, encajes..." (Genet 2003: 24). Ellos, como los vestidos para Eva Perón, cargan metonímicamente con el poder, ellos son las identidades que sostienen con su vestimenta: el Obispo una vez muerto sólo verá sus encajes y adornos. El personaje, la imagen y la construcción que de ella se hace pasan a valer más que la persona real: así, cuando el personaje de Arthur, el verdugo del burdel, muere por un balazo que entra por la ventana, no recibe la consideración de nadie, en todo caso lo que preocupa a todos es el cadáver tirado en el piso, que molesta para trabajar porque está obstruyendo el paso.

Así, se muere en el mundo para seguir viviendo como imagen en la escena. Este juego que Genet realiza con las posibilidades del teatro dentro del teatro, avanza hasta dejar sugerir la posibilidad de que la ficción y la realidad son indistinguibles: a medida que se desarrolla la acción de la obra, comprendemos que para los usuarios de las fantasías no está muy claro dónde termina la ilusión y dónde empieza la verdad. Genet juega con el entrecruzamiento de esas polaridades. Como dice Rosenzvaig, en Genet se insiste tanto en el juego con la apariencia que "el ser y el parecer" "pasan a segundo plano" (Rosenzvaig 2003: 118). Se trata de ese "juego de espejos al infinito" del que hablaba Martin Esslin ${ }^{63}$.

\subsection{Un teatro post-genetiano}

\footnotetext{
${ }^{63}$ Como dato interesante puede decirse que en las didascalias de Le Balcon se indica, en varias escenas, la necesidad de colocar espejos en las paredes, para multiplicar esa sensación de reflejo al infinito (Genet 2003).
} 
En el capítulo anterior comentábamos cómo Madame Lucienne, en la obra La nuit de madame Lucienne, mataba al teatro al matar al director: "No es a usted, es al teatro al que mato", decía este personaje; ella impugna, en este discurso final, toda la maquinaria teatral en su conjunto, pero haciendo hincapié en lo material, la utilería; aquí la utilería, más allá de la cuestión del género sexual, aparece literalmente, cuando su "falsedad" es repugnada en las palabras finales de madame Lucienne, siendo esa "repugnancia" la que origina su decisión de "matar al teatro". Como hemos visto, a lo largo de toda la obra son mencionados varios otros elementos de la utilería (el teléfono, la marioneta de rata) que van deviniendo imaginarios a medida que la obra instala, dentro de sí misma, esos umbrales del teatro-en-elteatro. La transfiguración de los objetos aparece también, como hemos visto, en ese pequeño teatro-en-el-teatro que inventan Claire y Solange en Les bonnes, cuando ellas utilizan una cortina como vestido, por ejemplo.

Parecería que el procedimiento del teatro dentro del teatro apuntase en Copi a resultados que, en principio, se parecen a los de Genet, aunque se los resuelva de distinta manera. En Genet se trataba de mostrar que siempre estamos representando, y que en todo caso el teatro no está en un nivel de ficcionalidad diferente del de la "vida real": los espejos en los que se reflejan los personajes, las imágenes que aquellos les devuelven, tienden a mostrar la pérdida del sujeto "real", que va olvidando sus referencias en ese laberinto infinito de espejos y donde el vestido y la utilería se van apoderando del "ser" en esa especie de transferencia metonímica. En Copi sucede algo similar pero, lejos de caer en el ambiente sacro y religioso con el que delinea el tema su predecesor, apunta más bien a dejar en evidencia el artificio teatral en su pura materialidad, en esa contingencia que son los accesorios de los que madame Lucienne, la verdadera, la persona simple, la de "carne y hueso", logra desprenderse simplemente asesinando al autor. 
Matar al autor es matar al teatro en forma literal, y es ahí donde se detiene el juego de espejos, el laberinto de apariencias que en Genet se llevaba hasta el extremo, con el fin, quizá, de encontrar un deseado punto en que desaparecería la distinción tajante entre "realidad" y "ficción". Copi parecería reducir esa oposición a un plano de materialidad, frenando así el "juego al infinito".

Así como los objetos de utilería instalan umbrales de teatralidad, podría decirse que Eva Perón, con el recurso del travestismo escénico, marca la apertura de la teatralidad más allá del plano "argumental" de la obra, es decir, hace que se sitúe en la puesta en escena misma, en los cuerpos mismos de los actores. Concretamente, el cuerpo de Facundo Bo (al menos en la primera representación, la de 1970), quien, desde esa masculinidad física cubierta de la feminidad externa, redobla la teatralidad; podría pensarse que esa desconexión entre la imagen de Eva y la "verdadera" Eva resulta sostenida escénicamente por esa otra desconexión entre el cuerpo del actor y el vestido que porta, o entre sexo y género, cuyo vínculo de causalidad resulta así, una vez más, desnaturalizado.

Al plantearse la posibilidad de que Evita no sea la "santa", dice Vázquez que "la diva no se eterniza, sino que se asume como mortal, ocupando un espacio privado que no da lugar a ningún mito" (Vázquez 2009): asumirse como mortal es asumirse como corporal y física. En Eva Perón, el laberinto de espejos genetiano se detiene porque su protagonista está viva de verdad. Y el discurso final de Perón (renuente, durante toda la pieza, a tomar la palabra, quizá por el dolor de cabeza que lo aqueja) nos dice que "Evita está viva", y eso según Aira ha de interpretarse literalmente: "A ella [a Eva] le dirige Perón el discurso final, que es la palabra y el estilo oficial, aplicado inconscientemente al artículo genuino. En ese punto la mentira dice la verdad sin saberlo, y eso hace política a la obra" (Aira 1991: 
107). O sea que la sentencia "Evita vive" se cumple literalmente en Copi, la Evita que "vive" es esa que ha escapado luego de dejar el cuerpo de la enfermera en su lugar. Y la adoración de Evita por parte de su pueblo investirá a su cuerpo de toda una serie de significaciones que la mantendrán viva: el pueblo, con su mirada, la sostiene; como ya hemos comentado en otros momentos de esta tesis, la "teatralidad" necesita de esa mirada para acontecer; el espectador es uno de los vértices sobre los que se apoya el fenómeno teatral, ese "engaño" al que elegimos entregarnos cada vez que nos sentamos en una butaca de teatro. Ezequiel Lozano veía algo así en Las criadas en cuanto a la adoración que las criadas dispensan a la Señora y que ayudan a conformar ese teatro ceremonial que ellas se fabrican: son sus miradas quienes construyen, también, la femineidad de la Señora y su poder (Lozano 2013: 809). Como se decía en el primer apartado del presente capítulo, el travestismo como recurso escénico no sería sino la manifestación "fenoménica" de algo que ya está aconteciendo en la lógica de las acciones de la pieza misma: en esa adoración espectatorial que se le tributa a la Señora, es no solamente su poder el que es asumido mediante la actuación y los accesorios, sino también la feminidad que aparece unida a la posición de clase, como se unen también la feminidad con la posición de clase en la obra de Copi. Y el punto de unión entre feminidad y poder se encuentra corporizado en los vestidos.

Parecería haber, entonces, elementos de la obra de Genet que reencontramos en el mundo de Copi, con la salvedad de que se les ha quitado el carácter religioso. "Evita vive" en la obra de Copi, pero no al modo en que lo hacía en la hagiografía peronista, donde era una santa casi incorpórea, sino literalmente, como una persona concreta, y, como se decía de madame Lucienne, "de carne y hueso", aunque esta Evita deba dejar en 
su lugar una imagen que, transvistiendo un cuerpo muerto, ajeno y usurpado, posibilite su supervivencia fuera de escena. 


\section{CAPÍTULO 7 \\ Espacios escénicos y espacios subjetivos}

\subsection{Encierro mental}

Si varios críticos recientes de las obras teatrales de Copi han prestado atención a la cuestión del "espacio" en relación con sus piezas, esto se debe a que ese concepto ha sido y es un aspecto importante para la semiótica teatral; la noción de espacio es importante, en primer lugar, porque, como afirman los escritores de semiótica teatral, desde el momento en que un teatrista "pone en escena" una obra de teatro, la está "espacializando" (Pavis 2008: 170), es decir, la está llevando a un espacio concreto, visualizable, que se construye en el escenario o en la sala teatral. Así, se puede distinguir según Anne Ubersfeld entre el "espacio teatral" (integrado por el espacio y sala), y el "espacio escénico" formado por el conjunto de signos de la escena, los objetos, la escenografía y el cuerpo de los actores (Trastoy y Zayas de Lima 2006: 225-226). Por otra parte, pero de manera similar, Patrice Pavis distingue entre un "espacio dramático" y un "espacio escénico". El primero es invisible, es un espacio construido por el espectador o el lector para fijar el marco de la evolución de la acción de los personajes; pertenece al texto dramático ${ }^{64}$ y sólo es visualizable si el espectador construye imaginariamente el espacio dramático. En cambio, el espacio escénico es visible y se concreta en la escenificación, y se trata de aquel espacio perceptible por parte del público sobre el o los escenarios. Sin embargo, hay todavía un espacio que, dentro de la tipología de Pavis, se encontraría entre los espacios que podemos distinguir dentro de la

\footnotetext{
${ }^{64}$ Es decir, el texto donde se especifica cómo deben ser la acción, los diálogos, los ambientes, entre otros elementos necesarios para la puesta en escena.
} 
totalidad del espacio dramático: nos referimos al espacio que no es necesariamente "visible", y éste es el espacio "extraescénico", también llamado "extraescena", como una categoría aparte pero que es de suma importancia (para el teatro y para este capítulo también): se trata de "[...] los elementos espaciales no visualizables por el espectador" (Sanchis Sinisterra 1991). Pero esto, que podría ser una característica inajenable de toda obra teatral, en Copi adquiere una mayor relevancia, en especial si tenemos en cuenta uno de los temas vertebradores de este trabajo: la identidad y el sujeto (en especial en cuanto a la problematización del sujeto y del cuerpo, a partir de la referencia a la división entre "espacio externo" y "espacio interno" del sujeto).

El primer aspecto que llama la atención en el teatro de Copi en lo que a utilización del espacio se refiere es la elección de espacios cerrados casi como una constante como marco dramático de acción de sus piezas. Tal como ponen de manifiesto algunos de los críticos recientes mencionados (como Stefano Casi o Isabelle Barbéris) la mayoría de las obras teatrales de Copi transcurren en un espacio cerrado, que suele ser una habitación u otra variedad de encierro capsular. La única excepción a esta unidad de lugar (y que, por excepcional, parece confirmar la regla) es La sombra de Wenceslao (1978), donde los espacios se abren, las líneas de pertenencia se desterritorializan: en realidad, en esta obra el espacio es importante también, pero no como espacio cerrado, sino en tanto aparece como abierto y disparado en múltipes direcciones. Tampoco puede decirse que en esta obra no aparezcan, como veremos en otro capítulo, algunas de las mismas obsesiones que se ven en el resto de la obra de Copi: así como Copi, en otros momentos de su escritura, nomadiza o desterritorializa las identidades, aquí esto se lleva a cabo por otro camino, que es el de la apertura hacia la distancia exagerada. 
En cambio, como decíamos más arriba, el resto de sus obras transcurre en el encierro o aislamiento más extremo. Copi lleva a cabo esto desde su primera obra teatral de importancia, La journée d'une rêveuse (1968), donde la acción está comprimida en una casa dentro de un jardín, hasta su última obra, Une visite inopportune (1987) donde un dramaturgo agoniza confinado en una habitación de hospital cerrada. Stefano Casi sugiere que hay algo de esta utilización del espacio que se vincula con la que lleva a cabo Federico García Lorca (a quien Copi admiraba) en La casa de Bernarda Alba (1936), donde el espacio físico es también una especie de espacio o prisión "mental":

Non sono situazioni prettamente claustrofobiche, perché poi i personaggi sembrano avere un'oggetiva libertà di movimento, dentro e fuori. Si tratta piuttosto di una claustrofobia più sottile, mentale, che li lega a un determinato luogo, scoglio fragile di ambigua salvezza in un océano di complessità, e che viene acuita da un incesante e abnorme parlare di altri luoghi, altri paesaggi, altri orizzonti. Pensando a García Lorca, primo grande amore di Copi $^{65}$, viene naturale pensare a La casa di Bernarda Alba come a una sorta di modelo di questi refugi e della drammatica opposizione dentro/fuori, alimentata dallo scatenamento furioso e delirante dei personaggi: nel modelo lorchiano troviamo infatti la netta separazione tra una casa di autoreclusione, al cui interno si aggirano come belve in gabbia donne attanagliate da una passione erotica inestinguibile, e un esterno abitato da maschi bramati e negati (Casi 2008: 47-48).

${ }^{65}$ Aquí Casi, en una nota al pie, hace alusión a un comentario hecho por su hermano Jorge Damonte sobre el amor de Copi por Lorca cuando era niño (Casi 2008: 47n) 
En esta obra de Lorca, el espacio teatral está relacionado con los "espacios mentales"; Lorca utiliza un "etraescena" que abarca al pueblo y muy especialmente a sus habitantes masculinos; el espacio de lo masculino aparece como opuesto al espacio "escénico" para construir esa distinción entre lo masculino y lo femenino, siendo el primero un espacio deseado pero a la vez temido. Los hombres del pueblo de Bernarda no son nunca vistos, sino figurados por los sonidos que vienen del exterior, o por los comentarios que las mujeres hacen sobre ellos.

Pero Stefano Casi también vincula este encierro que distingue a la acción de las obras de Copi con el encierro presente en obras del teatro del absurdo, especialmente de Samuel Beckett y de Harold Pinter, autores que Copi conocía muy bien, porque habían tenido una presencia grande en la época en que él comenzó a participar en el teatro, y de hecho él menciona al segundo en la entrevista con José Tcherkaski (1998: 80). Según Casi, esta estructura espacial/mental del absurdo tiene mucho en común con la de Copi:

Come nel primo Pinter i personaggi di Copi sono quasi sempre chiusi in una stanza, in attesa di qualcosa che non si comprende bene, in comunicazione con un "fuori", con un "altrove" che è al tempo stesso desiderato e minaccioso. Come dicevo, non si tratta né in Pinter né in Copi (né in Lorca) di rappresentazioni claustrofobiche, ma piuttosto di prigioni mentali in cui i personaggi si muovono nella doppia direzione del desierio/paura di ciò che sta oltre lo spazio "recintato". Siamo dunque di fronte a opere che non solo hanno tutte una rigorosa applicazione dell'unità di luogo 
(talvolta perfino di tempo), ma che mettono in scena situazioni e personaggi sotto assedio (Casi 2008: 48).

Lo absurdo tal como lo entienden esos autores mencionados no está ausente de Copi, pero no coincide del todo con ellos; por ejemplo, en lo que se refiere al espacio, no se apela a una indeterminación espacial tan flagrante como la que se ve en muchas obras del teatro del absurdo, entre otras diferencias que no vendría al caso comentar aquí. Quizá la obra de Copi más cercana al absurdo sea la primera, ya mencionada, La journée d'une rêveuse, donde se advierten ecos de lonesco. Copi parece tomar algo de esos autores, y lo que toma tiene que ver con ese juego entre atracción y rechazo de un espacio exterior desde el que se asedia a los personajes recluidos en el espacio visible de la escena.

En su artículo, Stefano Casi hace un recorrido por la obra teatral completa de Copi, en forma cronológica, y nos va mostrando los diversos avatares de esta "prisión mental" en la cual Copi encierra a sus personajes. Después de comentar La journée d'une rêveuse, Casi pasa a Eva Perón. Durante esta obra, la presunta agonía de Evita está circundada por amenazas; a través de los boletines que transmite la radio, sabemos que hay miles de personas en la calle, esperando macabramente la muerte de la primera dama: "La fuga finale è un'evasione dal doppio accerchiamiento che la stringe: dal fuori che è un intero popolo in attesa della sua morte, e dal dentro che è il perverso sistema relazionale constituito dai diversi personaggi" (Casi 2008: 51); estos personajes son la madre de Evita, Ibiza y Perón (aunque éste, como ya hemos comentado en el capítulo anterior, no habla mucho en la obra). Ahora bien, continúa Casi, "[...] la sua fuga è in realtà una fuga a metà, giocata sull'ambigua identità di morte e vita (fulcro strutturale di tutte le opere di Copi), perché Evita fugge viva ma rimane 
morta, sia pure nel corpo dell'infermiera (che è il suo doppio)" (51); estas reflexiones de Casi se acercan a las que hicimos sobre la fuga de Eva en el capítulo anterior. Así, entonces, el lugar en Eva Perón aparece, como dice Casi, como un apoyo estructural del engaño de su protagonista; el espacio donde transcurre la acción de la obra, la cámara mortuoria, funciona como un espacio teatral; cuando Evita sale de escena, sus colaboradores ponen el cadáver de la enfermera sobre un baúl, se le agrega una peluca y entonces, tal como comentamos cuando comparábamos esta obra con Le Balcon de Genet, entra "el pueblo": "des journalistes, des ministres, des bonnes sœurs, des voyeurs, des photographes, des ambassadrices, les petits chanteurs de la croix patagone, des miraculés, des esthéticiennes, des embaumeurs, des ecclésiastiques, des écoliers, des syndicalistes, les filles de la révolution péroniste, des infirmières portant des cierges et des couronnes de fleurs artificielles" (Copi 1986a: 133); estas personas sostienen con su mirada esa otra obra teatral, la de los funerales de Eva. Como hemos visto, la fuga de Evita hacia el espacio extraescénico posibilita su supervivencia: se trata de un intercambio entre el espacio mental y el espacio exterior amenazante que pone a los personajes "bajo asedio" (para utilizar las mismas palabras que Stefano Casi).

En L'homosexuel ou la difficulté de s'exprimer, es decir, la obra que Copi estrena seguidamente de Eva Perón, este "afuera" amenazante (pero también relacionado con el deseo) aparece en una forma más violenta. Ya hemos comentado el argumento de esta pieza en el capítulo 2 de esta tesis. En ella, el espacio externo relacionado con el deseo lo constituye el país de China, adonde la profesora de piano quiere llevarse a Irina; mientras que la "amenaza" la representan los lobos de la estepa siberiana, a los que se hace mención más de una vez. Para irse, los personajes deberían subirse a un trineo, y recorrer la estepa nevada y plagada de esos animales. Como ya 
hemos comentado, a medida que Irina es interrogada acerca de su sexualidad, va siendo presa del discurso, del diálogo que intenta definirla, hasta terminar completamente anulada; así lo explica Barbéris:

La dramaturgie de L'Homosexuel repose sur la mutilation progressive et la disparition d'Irina. Les "étapes de son agonie" sont aussi lentes et sûres que dans un rituel sacrificiel. Dans la scène IX, Garbo cherche à faire avouer Irina qui finira par avaler sa langue. Le duo amoureux vire alors à l'interrogatoire en quête de transparence absolue, tout au long des 138 répliques de cette scène d'aveu avortée. Les questions se concentrent sur les circonstances du changement de sexe d'Irina, dont la parole s'éteint progressivement (Barbéris 2014: 77).

Barbéris sugiere que Irina deviene infans (palabra latina que significa "sin habla", "sin voz") marioneta maleable y mutilada, que cuando abre la boca para hablar, no puede hacerlo, siendo así, prácticamente, una "poupée sans ventriloque" (Barbéris 2014: 77).

Así, a medida que avanzan los diálogos, se va generando una figuración de este personaje que la muestra como un cuerpo sin afuera ni adentro $^{66}$, reversible e intercambiable, pero no metafóricamente, sino literalmente. Esto queda especialmente de manifiesto en un pasaje que ya se ha comentado en el capítulo 1 de esta tesis, es decir, el momento en que Irina, que está embarazada, aborta a su hijo, pero lo hace a través del ano; nuevamente Barbéris:

\footnotetext{
${ }^{66}$ Como lo decía la misma Barbéris (2014: 90).
} 
L'immédiateté du passage de la vie à la mort, et l'évacuation du processus entre ces deux stades, sont des constantes chez Copi. Lieu de passage pour la semence, la nourriture ou encore la souris introduite dans son anus, le corps d'Irina, à l'image de l'éponge, affiche une indifférenciation qui vient contredire le titre de la pièce : Irina n'est pas identifiable en tant qu'homosexuel. Son sexe et sa sexualité sont indistincts, de même que son degré sexuel. La place du genre est laissée vide. Son corps est le réceptacle d'un désir aveugle et brutal, purement projectif et improductif. Sous le regard avide de ses bourrelles, elle devient un mollusque, un corps sans organe, un invertebrado (Barbéris 2014: 78)

La palabra "invertebrado" se encuentra en el texto original escrito por Copi, la palabra es pronunciada por Irina: "Vous savez ce que ça veut dire 'invertebrados' ? C'est de l'espagnol. Ça veut dire un animal qui n'a pas de vertèbres, comme les escargots" (Copi 1986: 173).

Si en Eva Perón ya había un cuestionamiento de la "realidad" del sujeto, cuando se planteaba la posibilidad de la simulación y del intercambio del espacio escénico por el extraescénico, aquí, un año después, en L'homosexuel ou la difficulté de s'exprimer, la distinción entre exterior e interior se desplaza hacia el sujeto, más bien hacia su misma constitución corporal.

Ya se ha citado, cuando hablábamos de esta pieza, el comentario crítico en que Aira pone de manifiesto lo llamativo del título, porque incluye dos palabras raras en el mundo de Copi: "homosexual" y "expresarse"; en la primera palabra encontramos una mirada patologizante, y en la segunda encontramos el "modelo expresivo" del género sexual: la "expresión" -con la cual el "homosexual" tendría "dificultad"- supondría que habría un "interior" 
constitutivo del cual el "exterior" es la manifestación: el interior de Irina, si lo hay, queda anulado: solo queda un cuerpo, vaciado de contenido. En Eva Perón el problema de la transformación tenía que ver con una cuestión de vestimenta y disfraz (es decir, de travestismo), pero en L'homosexuel ou la difficulté de s'exprimer, la transformación se dará en el mismo cuerpo orgánico del personaje. El cuerpo de Irina demuestra su fragilidad a través de esa configuración como un cuerpo mutilado, perforado, donde el límite entre el adentro y el afuera se ha debilitado, y donde las funciones excretoras se confunden con las reproductoras, tal como lo explicaba Barbéris. Así, entonces, cuando más arriba decíamos (siguiendo a Stefano Casi) que el "afuera" aparece como amenazante y a la vez deseado, este afuera debe entenderse no necesariamente como el "afuera de la casa", sino también como el "afuera del sujeto", o también "del cuerpo".

¿Cómo figura Copi ese "afuera de la casa"? La Siberia imaginada como "espacio extraescénico" parece extraida del imaginario del exotismo, con los lobos aullantes, los trineos, los nombres rusos deformados humorísticamente a través del estereotipo occidental sobre las lenguas de Rusia ("Garbenko", por ejemplo). Se podría relacionar todo esto con la manera en que en La casa de Bernarda Alba se usaban las coces del caballo contra la pared para indicar el espacio exterior masculino, o cómo se presentaba la imaginería andaluza de un modo a medio camino entre el realismo y la parodia. Pero, al igual que en esa obra de Lorca, y tal como ponía de manifiesto Casi, las presiones que asedian al sujeto no se limitan al exterior, al espacio extraescénico, sino que se reproducen en el interior escénico, en el espacio escénico visible. El personaje de Bernarda ejerce su poder tirano sobre sus hijas; el cayado que porta durante la obra semeja, de algún modo, el cetro del poder. Al igual que la Eva de Copi, o la Señora de Les bonnes de Genet, hay en Bernarda el ejercicio de un poder tiránico 
sobre los/las más débiles que se encuentran acompañando al personaje dentro del espacio cerrado de la escena. Según Anne Ubersfeld, en el juego de disfraz que las mucamas de Genet llevaban a cabo, transvistiéndose en Madame, se invertía el esquema actancial Sujeto-Objeto (Ubersfeld 1989: 75) ${ }^{67}$. Justamente esta reversibilidad, esta intercambiabilidad de los personajes, es la que "précède la neutralisation actancielle des Quatre jumelles", en palabras de Barbéris (2014: 73). La obra a la que esta crítica francesa se está refiriendo aquí fue estrenada muy poco después (fue en 1973), y también, como L'homosexuel ou la difficulté de s'exprimer, fue dirigida en su estreno por Jorge Lavelli. En semiótica teatral, un esquema actancial "se organiza alrededor de la relación sujeto que busca y objeto buscado" (Pavis 1996: 170), y esta relación es la que Copi anula en Les quattre jumelles, donde nuestro autor "pousse à bout la logique de l'indifferentiation des rôles du cérémoniel genétien, pour aboutir à une sorte de psychodrame où l'échange des rôles devient vertigineux" (Barbéris 2014: 82). Este intercambio "vertiginoso" de roles, donde el sujeto y el objeto se

\footnotetext{
${ }^{67}$ Esto es lo que dice Ubersfeld al respecto: "La escritura dramática de Genet duplica o hasta triplica el modelo actancial en razón de ese juego de espejos de la teatralización planteado por su escritura. En Las criadas, el sujeto Clara se convierte, al mismo tiempo, en virtud del trabajo de su propio 'teatro' imaginario, en el Objeto-Señora. El funcionamiento de 'roles' incrustados los unos en los otros (como en un juego de muñecas rusas) cuestiona el funcionamiento actancial clásico, pues el deseo de los sujetos posibles se convierte en una multitud de deseos en el interior de una ceremonia construida para satisfacerlos; el modelo estalla en sujetos parciales pero concurrentes en la ceremonia" (Ubersfeld 1989: 75); y luego esta autora habla de Le balcon, una obra que también hemos abordado en el capítulo anterior de esta tesis: "[a]sí podría explicarse el ensamblaje de los deseos de Madame Irma, de las putas y de los clientes en El balcón, de Genet. Un doble modelo, distanciado, muestra cómo la sustitución de la Corte por el Balcón (del Burdel por el palacio real), permite el estrangulamiento de la revolución; pero para ello se precisa de ese incesante deslizamiento metonímico que nos hace pasar, en El balcón, del Burdel a la Revolución y de nuevo al Burdel, de los Importantes a sus imágenes. Pero, entonces, ¿dónde está quién? El desplazamiento cuestiona el funcionamiento espacial del modelo actancial. Llegados a este punto clave, el modelo o los modelos actanciales, en su concurrencia o en su conflicto, sólo son comprensibles si hacemos intervenir la noción de espacialidad" (Ubersfeld 1989: 75).
} 
pierden en esa especie de laberinto de espejos genetiano, corre parejo, entonces, con una concepción de los personajes que en Copi aparecen representados como si fuesen maleables, destructibles y, como lo ha dicho Link, "[...] liberados de toda carga psicológica" (Link 2005: 346) ${ }^{68}$. Al hablar de la preferencia por los espacios cerrados en la dramaturgia de Copi, Barbéris califica sus piezas como "entrópicas"; probablemente el mejor ejemplo de esta idea de un espacio que se cierra entrópicamente sobre los personajes se encuentra precisamente en Les quatte jumelles. Aira dice de esta obra que

[...] no se puede contar, sólo describir; es menos un cuento que un cuadro, un "cuadro vivo" por mostrarse en escena, pero un "cuadro muerto" y mortal, por lo que muestra. Su argumento es algo así como un relato muy breve, momentáneo, que se extiende, no al modo lineal por cierto, en el espacio tiempo, a fuerza de repeticiones y variaciones. Como otras experiencias del arte contemporáneo, propone una espacialización paradójica de elementos de origen temporal [...]. El análogo es la pintura all over, como la de Jackson Pollock. No hay suspenso, ni centro: todo es centro, el máximo de intensidad se alcanza a los pocos segundos del comienzo, y se mantiene hasta el final -y más allá, virtualmente al infinito. El momento culminante de la tragedia, la muerte patética del héroe, sucede todo el tiempo. Es la tragedia all over (Aira 1991: 112).

68 O, como los describe Armando Llamas: "Los personajes de Copi nunca llegan a ser definidos, firmes, son agujereados, proteiformes" (Llamas citado por Tambascio 1997:111). 
Dado que el punto de tensión dramática más alto ya se encuentra alcanzado desde el principio, el "tiempo" no cobra entidad en la forma de una sucesividad cronológica, y por eso también, correlativamente, el esquema actancial está aplanado, se torna plenamente "espacio", lo cual va parejo con el aplanamiento de la psicología. En el siguiente apartado veremos otros ejemplos de esa importancia del espacio y de su relación estrecha con los cuerpos de los personajes.

\subsection{Uni-personal, des-personal}

Para continuar con esta lectura del espacio, debemos hablar de otras dos obras de Copi, dos unipersonales donde el travestismo se lleva al extremo. La primera obra es Loretta Strong (de 1974), y la otra, posterior, es Le frigo (de 1983). En ambas obras se produce un ejercicio de "dépersonnification" (Barbéris 2014: 85). Loretta Strong es una astronauta que está dentro de un satélite que va rumbo a la estrella Betelgeuse con el fin descabellado de sembrar oro, y que charla continuamente por teléfono con otra mujer, que no está presente, llamada Linda. Mientras conversa en un monólogo delirante, Loretta tiene sexo con murciélagos, ratas, la heladera, el horno, e incluso con el mismo oro, que se introduce en la vagina. El cuerpo de Loretta es, como había dicho Barbéris, una entidad sin adentro ni afuera (Barbéris 2014: 90): sobre el final de la obra, Loretta habla de "pepitas de oro que le salen por todos los poros", y que están "haciendo agujeros en las paredes del satélite"69. Y, para culminar la obra, Loretta decide "salir" de escena ("Je sors", son sus últimas palabras, y también las últimas de la pieza $\left.{ }^{70}\right)$; suponemos que, al salir del satélite, está saliendo al "espacio exterior" (como suelen llamar los astrónomos al espacio semivacío que

\footnotetext{
69 “J'ai des pépites qui me sortent par tous les pores ! Ça fait des trous dans les parois du satellite !" (Copi 1986a: 278).

${ }^{70}$ Copi 1986a: 278.
} 
rodea a los planetas en el Universo): pero, como ya podemos empezar a ver, esa salida al "espacio exterior" es en realidad una salida al exterior del sujeto.

En la puesta en escena de Javier Botana (protagonizada por Copi), este director había concebido una escenografía de color rosa que representaba la nave de Loretta como un interior burgués. Como parte del decorado se podía ver un inodoro gigante, una ducha, una heladera y un perchero. A lo largo de la pieza, Copi se transvestía en chica jugadora de tenis que mataba moscas con la raqueta. Luego se transvestía en tortuga, en papagayo, en oso, teniendo sexo con todas las criaturas, y luego terminaba desnudo y pintado de verde. Copi iba de un punto a otro del escenario, hacía aparecer a las criaturas, desaparecía él mismo por el inodoro, y luego reaparecía disfrazado con un vestido de lamé. Después se disfrazaba con una máscara de Lincoln ${ }^{71}$. El personaje que encarna Copi en Loretta va desintegrándose y mostrando su penetrabilidad con todo lo que se halla afuera de ella. El ya citado Stefano Casi, quien define a esta obra como la más "abstracta" y "lisérgica" de Copi (2008: 52), dice que el lugar del que habla Loretta "è un non luogo, qualcosa a metà tra un ambiente domestico e una navicella spaziale, che è sostanzialmente un involucro quasi biologico del personaggio stesso, una sua estensione o proiezione. Fuori da questo luogo sta, ancora una volta, un altrove insidioso e minaccioso" (Casi 2008: 52, subrayado mío). Ese involucro biologico que observa Casi en los personajes, parece un agenciamiento posibilitado por los objetos que rodean a Loretta, que a Casi le recuerdan la relación que en las obras de Pinter (especialmente The Dumb Waiter, de 1957) tienen los personajes con ellos: "Gli elettrodomestici di Loretta sono altrettante soglie di acceso all'esterno: un forno, un frigorífico, un tostapane. Non solo: la

\footnotetext{
${ }^{71}$ Los datos sobre esta puesta en escena están extraidos textualmente de Barbéris (2014: 87).
} 
minaccia degli uomini-scimmia si materializza nel cesso, dal quale gli invasori potrebbero entrare per assalire Loretta. $E$ naturalmente c'è il telefono, che rappresenta il canale attraverso cui viene evocato il fuori desiderato" (Casi 2008: 52). Es a través de esos objetos que se produce la comunicación entre el adentro y el afuera amenazante (y a la vez deseado).

En el otro unipersonal, Le frigo, Copi actuará nuevamente, interpretando diversos papeles que van sucediéndose y que incluso conviven en su mismo disfraz; ya hemos reseñado, en otro momento de la tesis, esta sucesión de disfraces; el actor encarna, de un lado, al personaje "L.", del otro lado al personaje de la madre de ésta, y del otro lado, también, es una rata, que cuelga del disfraz en la forma de un muñeco de goma espuma. Copi va transformándose a medida que pronuncia las palabras de su guión, como si estuviese poseído por los distintos papeles que va encarnando, de un modo similar al efecto que generaba la marioneta de rata en La nuit de madame Lucienne, como hemos visto en el capítulo 5 de esta tesis, cuando tratábamos a la marioneta de rata como una especie de umbral de teatralidad, a partir del cual se originaban las preguntas: “¿Quién manipula a quién?” y “¿Quién calza a quién?” (Barbéris 2014: 124); en realidad, el concepto de marioneta atraviesa las discusiones en torno a la actuación y al cuerpo del actor, que, dice Patrice Pavis, "se sitúa entre la espontaneidad y el control absoluto, entre un cuerpo natural o espontáneo y un cuerpo-marioneta enteramente encadenado y manipulado por su sujeto o procreador espiritual: el director de escena" (Pavis 2008: 107, subrayado mío). Así, entonces, el personaje de Le frigo muestra una fragmentación y, al mismo tiempo, un acto de posesión del sujeto actoral, que ya no es dueño de su papel, sino que es poseído por éste: "Le transformazioni previste dal testo sono frenetiche e vertiginose, e sembrano installarsi nel corpo del soggetto senza dargli tempo di aggiustarsi, di prepararsi a divenire 
compiutamente 'altro da sé', según nos dice otro crítico italiano al que ya hemos hecho alusión, Marco Pustianaz (2008: 35). En este artículo de Pustianaz se describe a los sujetos de Copi desde el concepto de la histeria, en un sentido que José Amícola (2000) ya había explorado también en relación con Copi y el travestismo en el marco de las poéticas camp. La histeria según Pustianaz supone un sujeto desequilibrado, des-centrado, "fuera de sí", y en general se la ha asociado a "tipos" determinados por algunas sociedades como histéricos (según los prejuicios epocales), como por ejemplo las mujeres o los homosexuales (Pustianaz 2008: 38); esa histeria adjudicada habitualmente a esos "tipos" suele situarse en la superficie de sus cuerpos como un síntoma del "il conflitto interiore costitutivo del trauma della soggettività" (39), es decir, "el trauma originario" (39). Por eso es que "performance isterica e teatralità copiana mostrano una profonda alleanza, legate sia al momento di dissidenza culturale postsessantotesca sia alla coscienza diasporica di Copi ${ }^{72 " ~(39) . ~ C o m o ~ y a ~ h e m o s ~}$ visto en el "Estado de la cuestión" de esta tesis, José Amícola había hablado del vínculo que se podría establecer entre la histeria y la sobredeterminación que ella conlleva para los cuerpos, y por eso el camp hacía tanto hincapié en las "superficies", como una manera de subrayar el carácter "representativo", todo lo cual estaría manifestado escénicamente en la actuación travesti, a partir de la exageración de lo melodramático y de la idea preconcebida de lo que es la feminidad.

Por todo lo dicho, y volviendo a la cuestión del espacio, ¿se puede seguir hablando de un espacio "interior" del sujeto y de otro "exterior" a él? Es lo que se plantea el citado Pustianaz, refiriéndose a Loretta Strong:

72 Con "conciencia diaspórica", Pustianaz alude al carácter de exiliado de Copi, y a su posición extraterritorial, es decir, un dato autobiográfico que influye no poco en la creación de sus personajes. 
Loretta Strong destruttura la stessa possibilità di parlare di soggetto, poiché quest'ultimo presuppone una chiusura organica. Quando i corpi nos riescono a rimanere chiusi (perché ad esempio la vagina di Loretta si muta in buco nero aspirante ogni cosa) come può esistere ancora la possibilità di parlare di "spazio", quello che in inglese si direbbe "outer space"? Persino il soggetto "fuori di sé" presupone che un interno e un esterno siano distinguibili. Che dire delle continue esplosioni a cui è soggetta Loretta e dei luoghi di passaggio che proliferano e aprono porte di conversione tra dentro e fuori? (Pustianaz 2008: 45)

Al perderse la "clausura orgánica", se pierde la posibilidad de hablar de "sujeto". La salida de Loretta hacia el espacio exterior es también, entonces, y como se ha dicho más arriba, una salida hacia el espacio exterior de la nave, que coincide con el espacio extraescénico. Cuando Barbéris sugería el término "despersonificación", se estaba refiriendo a la pérdida de la individualidad física y corporal que se pone en juego en esta obra, cuando el cuerpo de Loretta se va fundiendo y penetrando con el espacio circundante, poniendo en crisis la distinción entre los dos espacios.

Esa problematización o puesta en crisis ya está, según Butler, en las performances drag que Esther Newton analizaba en su lectura pionera de este fenómeno: según Butler, del análisis que hace Newton puede deducirse que "la 'travestida' trastoca completamente la división entre espacio psíquico interno y externo" (Butler 2007: 267); en palabras de la misma Newton, citada por Butler: "En su forma más compleja, [la travestida] presenta una doble inversión que afirma: «Las apariencias engañan». La travestida afirma [curiosa personificación de Newton]: «Mi apariencia 'exterior' es femenina, pero mi esencia 'interior' [del cuerpo] es masculina». 
Al mismo tiempo se representa la inversión opuesta: «Mi apariencia 'exterior' [mi cuerpo, mi género] es masculina, pero mi esencia 'interior' [yo] es femenina»" (Butler 2007: 267-268).

Pero en Copi, aunque la dislocación subjetiva se produce a través de sus cuerpos y de sus disfraces, esa distinción entre el actor o cuerpo y su disfraz no se puede seguir sosteniendo. El travestismo de Loretta Strong y el de Le frigo suponen entonces, en Copi, un paso más allá del mero "transformismo"; se trata más bien de la excusa o punto de partida para esa "simultaneidad ambigua" que según el citado Marco Pustianaz encontramos en el personaje de Le frigo:

Può essere quello di una donna che non ha finito di travestirsi da maschio; quello di una donna che si è dimenticato di essersi vestito prima da donna. La simultaneità ambigua del travestimento è leggibile in ogni direzione perché non può essere risolta se non facendo appello a un dato biológico che non abbiamo quasi mai come "dato di fatto" nel teatro di Copi. L. [protagonista de Le Frigo] elude la differenza fra soggeto "vestito" e "travestito" (Pustianaz 2008: 37).

El "dato biológico" sugiere Pustianaz, casi no existe como "dato de hecho": el disfraz es en Copi una marca de teatralidad, pero también parece ser el único fundamento para la identidad, el único "dato de hecho". Entonces, el travestismo de estos personajes es total, y por eso el personaje de L. elude, dice este crítico, la diferencia entre "vestido" y "travestido".

Entonces, ¿podemos seguir hablando de "travestismo" en Copi? Aun más: ese travestismo, ¿no iría más allá del cambio de género? Después de 
todo, por lo que venimos viendo, la posibilidad de disfrazarse incluye también la de los animales, como podemos ver en la marioneta de rata que cuelga de L. en Le frigo, o la que es calzada en La nuit de madame Lucienne. Y además, sabemos que Copi se había disfrazado de animal en otras obras: de pollo y de lagarto, por ejemplo, en las primeras incursiones teatrales de los años 60 (Barbéris 2008: 78 y 79), o de tortuga y de rata (Tcherkaski 1998: 49). Los animales son una presencia importante en la obra de nuestro autor; según Eduardo Muslip, en su obra los animales "aparecen como un entorno de lo humano que nos recuerda que pertenecemos a una especie más, con pulsiones tan básicas como las de las otras" (Muslip 2009b); son esos animales que, como los lobos siberianos de L'homosexuel ou la difficulté de s'exprimer, rodean a los humanos, conformando aquello de lo que el Hombre se ha ido separando en su camino a la humanización, aunque pugna todo el tiempo por reaparecer. Pero aun más, todo esto va más allá de los animales, ya que, como vimos en Loretta Strong, el sujeto que la protagoniza termina penetrándose con todo lo que la rodea: animales, pero también, objetos.

En una reseña de 1974 de una obra de Copi, una crítica francesa llamada Nathalie Godart dijo: "Tout est costume dit Copi, même la nudité, même les objets" (citada por Barbéris 2014: 120n). Los objetos son también disfraces porque guardan con los personajes esa relación metonímica, una relación que, vemos, se acentúa en Loretta Strong, donde el espacio escénico coincide entonces, como hemos visto, con el espacio interno del sujeto: porque ese límite entre el espacio psíquico interno y el espacio externo se ha perdido o nunca existió realmente. $\mathrm{Y}$ es en el "espacio escénico", "visible" donde encontramos los objetos teatrales, junto con la escenografía y el decorado. 
Pero la cuestión de los objetos destacada por Nathalie Godart puede continuarse. Al comentar Le Frigo, Barbéris llama la atención sobre el objeto que da nombre a la pieza, y la relación que tienen los personajes con él, una relación que, como comentamos más atrás, llevaba a Stefano Casi a reflexionar sobre una relación parecida que se puede encontrar en The Dumb Waiter de Pinter. Barbéris nos dice que esa heladera, que a lo largo de la pieza de Copi aparece como un objeto conflictivo del que no se sabe mucho ("Qu'est-ce qu'il y a dedans ?"73), en realidad lo que hace es tematizar emblemáticamente esa relación metonímica que nuestro autor tiene con el mundo, basadas según Barbéris en "[l]a boîte et l'emboîtement", que son, dice esta crítica, "des unités élémentaires" de su teatro (Barbéris 2014: 11974). Los cuerpos de Copi son también cajas que contienen a los sujetos. Entonces, la heladera aparecería como "dernière coulisse, dernière costume, dernière peau" (Barbéris 2014: 120). El límite de la piel es el mismo límite que hay entre los personajes y los objetos que los rodean, es decir entre sus psiquis y el espacio escénico.

Y si, por otra parte, y como decía Pustianaz, los personajes como "L" (de Le Frigo) eluden la diferencia entre sujeto vestido y travestido, lo mismo puede decirse, en la dirección inversa (junto con Nathalie Godart), del cuerpo vestido o desnudo. En Copi incluso la desnudez sería, así, un vestido. En una lectura que Beatriz Trastoy y Perla Zayas de Lima hacen de

\footnotetext{
${ }^{73}$ Barbéris 2014: 120.

74 "La boîte et l'emboîtement sont des unités élémentaires du théâtre de Copi qui regorge de placards, de trappes, de valises, de frigo. Accessoire dynamique, il s'agit d'abord d'un accélérateur dramaturgique participant du théâtre affolé/débordé de Copi. Multipliant les passages, la boîte est emblématique du rapport métonymique que le théâtre de Copi entretient avec le monde. On pourrait se lancer dans une énumération et un classement des différentes boîtes : les 'transportables' (valises, malles, sacs), les 'vestimentaires' (costumes, blouses, djellabas), les 'véhicules' (traîneaux, capsule spatiale, charrette, chaise à porteurs), les 'hermétiques' (frigos, four, poubelle), les 'matricielles' ('vagine', anus, boudin, crâne), les 'optiques' (kaléidoscope, psyché), les 'mortuaires' (mausolée, cercueil, pyramide mortuaire)" (Barbéris 2014: 119).
} 
esta cuestión en el teatro, ellas evocan un comentario de Richard Stechner: "la desnudez es un traje" (Trastoy y Zayas de Lima 2006: 112). Lo curioso del texto de Trastoy y Zayas de Lima está en que estas críticas teatrales toman como ejemplo el teatro de Jorge Lavelli, específicamente su propia puesta en escena de Les quattre jumelles de Copi, y también algunos comentarios que el director hace sobre ella:

[Jorge Lavelli] propone una variante de la idea de Stechner de que "la desnudez es un traje" [...], en tanto considera que, desde el momento en que el actor está en el escenario, el cuerpo no se muestra desnudo como en la realidad sino inscripto en una cierta artificialidad. Se trataría de otro cuerpo, vestido por el maquillaje, el tatuaje o simplemente por la luz que lo baña. Refiriéndose a su puesta de Las cuatro gemelas, de Copi (1974), Lavelli señala cómo los personajes femeninos pasan por estados diferentes incluso a través del traje (Trastoy y Zayas de Lima 2006: 112).

Y, luego, en una nota al pie, las autoras citan directamente a Lavelli hablando de las gemelas protagonistas:

No solamente se comportan como hombres, sino que están vestidas como hombres. Pero en las transformaciones sucesivas usan trajes que evocan momentos diferentes de la vida [...] Al final de la obra esos personajes recuperan -ganan o recuperan- su integridad física. Entonces aparecen desprovistos de traje, de cualquier accesorio. Es decir que lo que ganan o recuperan, en cierta medida, es su virginidad [...] esos personajes se muestran en su total desnudez. Pero los actores o las actrices están 
protegidos por lo que yo llamo maquillaje, pintura. Eso los protege, protege su aspecto privado [...] (Lavelli entrevistado por Tcherkaski 1983: 62-63).

En esas palabras de Lavelli puede verse, entonces, esta importancia del vestuario para el teatro de Copi; comprendiendo que tanto el vestuario, como el maquillaje o los accesorios, son en Copi algo más que agregados: son elementos determinantes de la identidad, tal como venimos viendo en esta tesis cuando nos referimos a los accesorios teatrales, que en el capítulo 4 se han analizado como "prótesis" en un sentido similar al que le daba Beatriz Preciado, y cuyo paradigma es el dildo: "Al reconfigurar los límites erógenos del cuerpo follador/follado, el dildo viene a poner en cuestión la idea de que los límites de la carne coinciden con los límites del cuerpo" (Preciado 2011: 76). El dildo como paradigma del sexo prostésico implica un involucro biologico (para decirlo con las palabras de Stefano Casi, en italiano, cuando hablaba del cuerpo de Loretta Strong en su vínculo de penetrabilidad con el ambiente, con la sala burguesa del interior de su nave, pero también con el espacio exterior a ella), y es similar al vínculo que establecen entre sí la mano y la marioneta, es decir, una penetrabilidad mutua: ambos se transvisten entre sí.

Los personajes de Copi son sujetos que están "fuera de sí", lo cual implica estar "fuera del cuerpo", siempre que se entienda el cuerpo como el encerrojamiento orgánico que define los límites entre los individuos, y que es fragmentado, desmantelado cuando las fuerzas que lo ponen "bajo asedio" penetran en su espacio interior, rompen ese límite que es, y siempre ha sido, artificial: el disfraz, entonces, el travestismo, es el punto en el que teatro y prótesis confluyen, y que Copi vuelve parte fundamental de su 
poética, en la cual siempre han sido fundamentales la piel y sus confines (Barbéris 2008: 73).

A lo largo de este capítulo hemos visto cómo, a través de la década del 70, desde Eva Perón, y llegando hasta principios de los 80 (con Le Frigo), Copi va trabajando en su teatro con la importante cuestión del espacio, y vimos cómo esta noción, que pudo no haber sido consciente para él, tiene que ver con su concepción del sujeto y de la identidad. El travestismo que aparecía en Eva Perón, si bien era novedoso, resulta un tanto tímido en comparación con el que vemos en Loretta Strong y Le Frigo, donde parece haber un travestismo que podríamos llamar "total", donde la vestimenta es una parte casi orgánica del sujeto, y donde éste aparece directamente "fuera de sí", como proponía Marco Pustianaz. Salirse "de-sí" en Copi es literalmente destruir el límite (ficticio, construido) entre espacio interior y exterior, dejar que las fuerzas animales, salvajes, del espacio exterior (si es que éste existe), penetren en el interior del sujeto, que es también un interior escénico. Desde ese comienzo tímido del travestismo, pasando por las otras obras que se han revisado aquí, podría decirse que los lobos siberianos que asediaban desde el exterior han ido invadiendo la sala interior burguesa. 


\section{CAPÍTULO 8 \\ Más allá del teatro}

Hasta ahora hemos observado cómo Copi trabaja en sus obras con la identidad, los cuerpos y los géneros, muy especialmente en el medio teatral. Pero es cierto que actualmente ningún acercamiento crítico a la obra de este autor puede evitar tener en cuenta que participó, además de en el teatro, también en la historieta y la narrativa. Si bien en esta tesis se ha hecho hincapié, hasta ahora, en el arte dramático, también es cierto que la noción desde la que partimos, la "teatralidad", podría entenderse, como ya se ha dicho, como un concepto que va más allá del teatro propiamente dicho: como decía Aira refiriéndose a Copi, "[t]oda su obra es teatro, pero el teatro mismo es la consumación de la metáfora" (Aira 1991: 116); la teatralidad, como elemento configurador o vehiculizador del problema identitario -y con él, del problema de los cuerpos y los géneros- puede encontrarse en los otros medios artísticos frecuentados por él, entre los cuales existen no pocos vínculos y diálogos, por lo cual sería incompleto un estudio que dejara de lado esas relaciones. La pregunta que se nos plantea es de qué modo aparece esa problemática en los otros medios artísticos.

Hay que considerar que todas esas artes en las que Copi participó no se mantuvieron separadas como compartimientos estancos entre los cuales no había relación, sino que él trabajó en ellas como si de unidades de experimentación artística se tratase, cada una de las cuales enriqueció a las demás. La importancia que se acuerda al polifacetismo de Copi descansa menos en un reconocimiento del gran talento que pone en juego para llevarlo a cabo que en el papel efectivo que cada una de las artes 
practicadas por él ejerce sobre el sistema total de su obra. El tránsito de Copi entre la historieta, el teatro y la narrativa da como resultado una presencia de rasgos de cada una de esas actividades dentro de las otras. No es una obra que haya que leer como en una manifestación triple y diferenciada, sino como un proyecto estético ubicado en la intersección de esos tres medios, como si se pudiese establecer una discusión continua en torno a las posibilidades de cada uno de ellos y de su relación con los demás.

Así, por ejemplo, el ya citado Stefano Casi aborda las historietas de Copi desde el punto de vista de su "teatralidad". Este crítico sugiere que la primera evidencia que al leer el humor gráfico de Copi nos lleva a pensar en el teatro es precisamente la disposición de la viñeta, que nos recuerda a un proscenio, en el medio del cual vemos a la Mujer Sentada y a sus acompañantes, que siempre llegan desde un costado, remedando, de algún modo, la entrada de los personajes en las escenas teatrales (Casi 2012: 120). El resultado es, como ha dicho Aira (1991) un "punto de vista fijo" (14), mediante el cual, con la mirada, como si fuésemos espectadores teatrales, captamos la interacción de dos personajes ubicados en una oposición simétrica, uno a la izquierda y otro a la derecha (el de la derecha suele ser la Mujer Sentada ${ }^{75}$ ) en una suerte de muy clásica y convencional escena de diálogo teatral (Casi 2012: 120).

Por otra parte, Marcos Rosenzvaig califica la estética de Copi como "teatrocómic" y "novelacómic" (2003: 17), y dirá que se trata de un "teatro dibujado": "Un teatro dibujado que sucede con la velocidad de los dibujos. No hay descanso, todo es un continuo separado entre cuadro y cuadro, entre dibujo y dibujo. Copi dibuja con los actores, y esta manera de concebir

\footnotetext{
${ }^{75}$ Aunque, por supuesto, La femme assise no fue la única tira cómica que dibujó, pero sí la más popular y con más continuidad en el tiempo.
} 
el teatro lo hace ser creador de un lenguaje" (Rosenzvaig 2003: 17). Para Rosenzvaig, habría una especie de sucesión historietística en la manera en que los cuadros teatrales se van manifestando en las piezas teatrales, algo que no podíamos ver en la quietud de sus cómics. A su vez, en su teatro hay un uso de lo caricaturesco que estaría dado por el origen de Copi como dibujante humorístico: "La caricatura fija un gesto, condensa en él todo el significante. El tiempo se congela en ese espacio temporal, hasta que de ese gesto se pasa al cuadro siguiente con un nuevo gesto. La comicidad se logra en la mecánica del gesto, de forma que el personaje es una mezcla entre algo humano y algo mecánico" (Rosenzvaig 2003: 17).

La "velocidad" de las acciones de su teatro puede verse también en sus narraciones, donde los hechos se suceden casi sin darnos tiempo a acomodarnos; esta velocidad recuerda de algún modo a la historieta, pero no precisamente a la historieta que Copi practicó, ya que, como decíamos, ésta se caracteriza por el estatismo, contrariamente a la historieta más "cinematográfica"; la sucesión rápida de acciones en las narraciones de Copi parece provenir más bien de la vertiente más clásica de la historieta o quizá, incluso, de la estética de los dibujos animados, como se puede deducir de lo que dice Alicia Montes refiriéndose al "mundo hiperbólico" que parece tomar Copi de ese producto audiovisual (Montes 2010: 106-107). Tal vez sea el "sketch" teatral el origen más evidente de esa velocidad, como lo investiga Barbéris en un artículo (2008) donde demuestra que en sus inicios teatrales de los sesenta, Copi había explorado el sketch como una unidad mínima que luego daría lugar a mecánicas fundamentales de su poética ${ }^{76}$.

Pareciera que, por una especie de economía narrativa, los elementos que no pueden encontrar lugar en un medio artístico (es decir, que lo

\footnotetext{
${ }^{76}$ Los sketches de los 60 a los que se refiere Barbéris se titularon: Sainte Geneviève dans sa baignoire (1966-1967), L'Alligator (1966), Noël dans les îles du Pacifique (1966) y Le Thé (1966) (Barbéris 2008).
} 
desbordan) deben pasar a otro medio en el que se reinterpretan. Por todo esto César Aira dice que esas distintas exploraciones artísticas de Copi deben entenderse como "precedencias flotantes" (1991: 14), es decir, que no hay un orden dictado por una cronología evolutiva de encajonamientos de elementos de un medio hacia otro, sino por un cambio constante que puede leerse de adelante hacia atrás y viceversa ${ }^{77}$.

Justamente es César Aira quien define a la Mujer Sentada, a la que Copi ya dibujaba, como vimos más arriba, desde antes de estrenar su primera gran obra, como un "proto-teatro" (13); para Aira el teatro estuvo antes que todo (13). Por eso no es casual que para Jorge Monteleone (2012) todo inicie también en ese proto-teatro que es la Mujer Sentada. Este crítico traza una interesante interpretación del derrotero "medial” de Copi. Según él, en las réplicas absurdas que se dan entre sí los personajes de La femme assise, que funcionan a nivel del lenguaje (dado que sus personajes se mueven poco) ya está contenida (aunque tácita) la violencia que Copi llevará al extremo, luego, en el teatro: "Esas pequeñas violencias ofrecidas a las fijezas de las oposiciones que se concentra en las tiras, casi siempre por efecto del lenguaje, se expandirá en las tres dimensiones del teatro". En las escenas teatrales de Copi se explorará la violencia, pero se irá más allá de esas "pequeñas violencias lingüísticas" del cómic, convirtiéndola en violencia física real; aunque, aun así, subsistirá una violencia no relatada en escena (debido a las limitaciones que supone el teatro, que es ante todo un conjunto de objetos reales, en un espacio real). Entonces, según Monteleone, Copi se dará cuenta de que "necesita de la novela para que lo transitivo del indicio relatado en la escena teatral se expanda todavía más, como si rebasara la escena misma hacia una indeterminada multiplicación

\footnotetext{
${ }_{77}$ Patricio Pron (2007) realiza un buen acercamiento a la importancia del humor gráfico en Copi, así como también Laura Vázquez (2009)
} 
imaginaria, el golpe de dados del espectáculo teatral -como gustaba definirlo78 - elevado al cubo". Este "rebasamiento de la escena" hacia la "indeterminada multiplicación imaginaria" se ve, según Monteleone, en la sucesión de escenas, decorados, vestimentas y acciones de las obras narrativas, que se caracterizan por su barroquismo y por la desmesura. Habría todo un campo de posibilidades que en el género del teatro no llegaban a desarrollarse por esa limitación física que implica la escena.

En efecto, en la narrativa de Copi son más comunes los sucesos espectaculares, las catástrofes, la velocidad, la violencia. En un corto espacio de tiempo puede suceder absolutamente todo. Esto lo distancia de su cómic y, en menor medida, de su teatro. Aira se detiene en los cuentos de Une langouste pour deux (1978), señalando que esos cuentos, por su "visualidad exacerbada" y sus "complicadas catástrofes", parecieran ser las historias de Copi que la factura escueta y minimalista de sus cómics no habría permitido aparecer (Aira 1991: 41). Es como si Copi fuera desplazándose por los distintos soportes y reacomodando sus procedimientos según sus posibilidades.

En la novela Le bal des folles, el narrador (llamado Copi) enuncia ya desde el primer capítulo que él se proponía originalmente escribir una novela sobre travestis: "[...] parce que je me plais à inventer des situations entre eux, mais je l'ai déjà fait dans le théâtre, c'est plus beau que dans un roman où on ne voit rien, et le travesti doit être vu" (Copi 1999: 12, subrayado mío). Es decir que en Copi está esa preocupación por lo visual que es tan importante para lo teatral, y que según Aira aparecería en forma "exacerbada" en la narrativa (1991: 41).

\footnotetext{
${ }^{78}$ Monteleone se está refiriendo a una declaración de Copi en la entrevista con Tcherkaski: "[...] creo que cada espectáculo debe ser como un golpe de dados en el conjunto de todas las posibilidades que el teatro permite, de todo lo que se ha hecho y de lo que se puede hacer en teatro" (Tcherkaski 1998: 86).
} 
Ahora bien, aunque el narrador de Le bal des folles diga que escribir una novela sobre travestis era su intención original ( $\mathrm{y}$ aunque ellas aparezcan a lo largo de toda la obra), su verdadero propósito es escribir sobre su gran amor, Pietro Gentiluomo, un joven italiano con el que tuvo una historia de amor a lo largo de los años. Así, Le bal des folles alterna dos líneas argumentales: la primera es aquella en la cual "Copi" escribe su novela "sobre travestis", y los avatares que se dan en medio: olvido o pérdida del manuscrito por efecto del alcohol y las drogas, asesinatos en los que se ve implicado, encuentros y coincidencias extravagantes, explosiones, sadomasoquismo, todo esto le pasa al narrador durante una semana. Esta narración se alterna armónicamente, mientras, con la otra línea argumental, que es la historia de la relación de "Copi" y Pietro Gentiluomo.

La historia de su amor con Pietro es también la historia de los conflictos de "Copi" con su antagonista, una mujer llamada Marilyn, quien dirige a un grupo de travestis, y que se convierte en rival de "Copi" al arrebatarle a Pietro en varias ocasiones. Además, Marilyn se instala en la casa del narrador con toda su banda de travestis, y empiezan a convertir a Pierre en mujer: le inyectan hormonas, lo depilan, lo maquillan y lo visten con ropas femeninas. Mientras tanto, "Copi" debe mantenerlos a todos, y para eso debe dibujar más de lo que dibuja habitualmente (aunque, según declara, odia su trabajo); también le es arrebatado su cuarto de trabajo, y se ve obligado a dibujar en la cocina.

El argumento de esta historia recordada es difícil de resumir. Pero en suma, se trata de la odisea de "Copi" en su lucha contra Marilyn por el amor de Pietro. En el devenir travesti que va afectando a Pietro, éste decide, finalmente, hacerse una operación de cambio de sexo, es decir, pasar de un estado que podríamos considerar como "travestismo" hacia el estado que se podría denominar "transexualidad". En una de las últimas escenas de esta 
historia de amor, en una relación sexual de "Copi" con Pietro, el primero introduce su mano en el cuerpo del otro, a través de un sobrenatural ombligo del que el italiano está dotado, y que comunica directamente con el interior del cuerpo (además de poseer virtudes erógenas); con su mano, "Copi" atraviesa las vísceras y llega hasta tocar el corazón con la mano. Se duermen, y al despertar, "Copi" comprueba que Pietro ha muerto (Copi 1999: 140). Según Aira, en la reconstrucción de esta historia de amor "[h]ay una escalada de proximidad: de la mirada, que presupone una distancia, al olor, que la disminuye, y de ahí al tacto, que la anula: la historia terminará cuando Copi llegue a tocar el corazón de Pietro" (Aira 1991: 54). La mirada, por el contrario, mantenía al objeto a distancia: "debería haberte contemplado vivir de lejos, con gemelos... pero tenía necesidad de tu olor como blanco de mi mirada", dice el narrador. Es decir, aclara Aira, "un olor como blanco de la mirada asesina" (54). La progresión corporal y material en la transformación de Pietro tendrá su último avatar en esta penetración corporal, que lleva a la muerte de Pietro, al tiempo que "Copi" lo olvida y que su historia es escrita. "Copi" puede olvidar así a su antiguo amor, ya lo ha matado ${ }^{79}$, y así, la novela "se escribe por sí misma", como dice el narrador. La novela habla de una novela que el escitor quiere escribir, y mientras la planea, en realidad, ya la está escribiendo. Así, se terminaría el pasaje que Copi efectúa desde el teatro, o sea el arte de la mirada ${ }^{80}$, hacia la narrativa,

\footnotetext{
79 Según Link: "El escritor que escribe en la novela de Copi [y que se llama como él] escribe y dibuja para sobrevivir: entrega sus dibujos a diarios franceses y sus manuscritos a un editor que confía en su talento a cambio del dinero que le permitirá seguir llevando el 'tren de vida' que la novela necesita para durar en el tiempo. Pero también escribe para sobrevivir a la pena infinita de un amor perdido para siempre, es decir: para matar esa pena, matando el amor, al mismo tiempo" (Link 2005: 346).

${ }^{80}$ Como dice Josette Féral, el teatro "it is a process of looking at or being looked at" (Féral 2002: 6). Además, como dice Pavis, "[e]l origen griego de la palabra teatro, el theatron, pone de manifiesto una propiedad fundamental, aunque olvidada, de este arte: es el lugar donde el público contempla una acción que le es presentada en otro sitio. En efecto, el teatro es un punto de vista sobre un acontecimiento: una mirada, un ángulo de visión y de rayos ópticos lo constituyen. Sólo en la medida en que desplaza la
} 
que, en esta novela al menos, realiza una progresión hacia el tacto.

Ya se ha mencionado esta novela en capítulos anteriores; como se recordará, el personaje protagonista "Copi" gusta del sadomasoquismo. En un momento de la historia, el personaje "Copi" se da cuenta de que una loca llamada Jean-Marie lo sigue. La loca ha descubierto que "Copi" está implicado en un asesinato, así que lo extorsiona pidiéndole un favor. Ella quiere que "Copi" la mate, para lo cual lo invita a pasar a su departamento. Pero el asesinato deberá llevarse a cabo, según el deseo de Jean-Marie, a través de un ritual sadomasoquista:

Elle sort une seringue du frigidaire, la fait boullir, me demande si je veux une piqûre d'héroïne avant de la tuer. Et si je me refusais? Elle me dénoncerait à la pólice, j'ai intérêt à la tuer. Comment? C'est à moi de choisir, elle a plusieurs appareils de torture mécaniques et électriques. Elle me fait passer dans une autre chambre que je n'avais pas soupçonnée, l'entrée est cachée par un tapis marocain, il y a une grande table de cuisine au milieu, des appareils de torture autor plus compliqués les uns que les autres, une cage avec des hamsters. Elle s'enlève le pantalón, me montre sa jambe : je comprends pourquoi elle boite, sa jambe est traversée d'aiguilles de crochet. Elle me tend un canif, me demande de lui enfoncer dans le mollet, je le fais, elle râlle de plaisir, se couche sur la table de cuisine, me demande de lui mettre un garrot à la hauteur de la cuisse et de lui scier le genou. Je n'ose pas, je tremble. Prends des amphétamines, me dit-elle. J'en avale une poignée. Raconte-moi comment tu as tué la vieille, me suppliet-elle. J'invente : j'ai pissé sur elle, je lui ai d'abord mordu la 
jugulaire. J'enfonce le couteau dans le genou, lui sépare la rotule, il hurle de plaisir. Coupe-moi le ventre, hurle-t-il, fais moi une césarienne ! Je vais chauffer au feu rouge un couteau de cuisine, pendant qu'il chauffe je vais chercher un hámster que je lui enfonce dans le cul, il se contorsionne, je vais chercher une hache, je lui coupe le pied, je m'acharne sur le tibia, il crie trop fort, je lui mets une serviette déjà imbibée de sang dans la bouche, le couteau est déjà rouge, je l'enfonce dans le nombril, je descends en remuant bien les intestins, je fais éclater la vessie, l'urine se mélange avec le sang et les excrements, j'y plonge ma main, il y a quelque chose qui bouge, c'est le hamster toujours vivant, je l'attrape bien fort dans ma main, je le sors à l'exterieur, il se débat, pousse des petits cris d'oiseau, les autres hamsters dans leur cage font de même, je lui mords le cou jusqu'à ce qu'il ait cessé de crier, il est mort. Le rouquin Jean-Marie râle encore. Je lui défonce le crâne d'un coup d'hache (Copi 1999: 104-105)

Llama la atención el grado de violencia ejercida sobre el cuerpo de JeanMarie. No se trata de flagelos realizados con látigos $u$ otros objetos lacerantes, sino que directamente se pasa a la mutilación mediante el uso de herramientas de trabajo. Pero además, se trata de una mutilación que abre el cuerpo hacia afuera, y que hace que todas las vísceras, los humores corporales, queden al descubierto, y se mezclen indiferenciadamente. No parece haber aquí un "alma" o un sentimiento que permitan amor o reconocimiento en el otro: el cuerpo se convierte en pura carne ${ }^{81}$ : es decir,

\footnotetext{
81 Dice Rosenzvaig: "No somos otra cosa que eso: carne que se oscurece con la muerte. Desacralizado el cuerpo, el próximo paso será el vaciamiento. No hay espacio para la melancolía, el recuerdo o el espíritu. El hombre no es más que carne, materia orgánica que desaparece" (2003: 68). De este modo, según este crítico, en esa correlación que en la novela se da entre el asesinato del objeto de amor y de escritura de la historia de la relación amorosa, "[l]a novela se fagocita, se autodestruye como la carne" (68).
} 
la subjetividad es reducida a lo material. Quizá en ese sentido es que Link dice, en un comentario que ya hemos citado en el capítulo anterior, que los personajes de Copi están "liberados de toda carga psicológica" (2005: 346). Se trata de una psicología sin complicaciones, extrema y melodramática, que responde, en parte, al trazo grueso que caracteriza a la caricatura humorística. Habría allí una suerte de "comportamentalismo" ("comportementalisme") del cual parece haberse evacuado la psicología (Barbéris 2014: 52). Como decíamos en el capítulo anterior al hablar de Loretta Strong y de cómo su personaje se fundía con el espacio circundante a partir de la destrucción del límite corporal, aquí también se rompe ese límite entre adentro y afuera: estamos ante un espacio interior hecho pedazos, reducido a su pura expresión material; el cuerpo de la loca Jean Marie, como el de Pietro, como el de Loretta Strong, o el de Irina, son, como decía Isabelle Barbéris, entidades reversibles, sin adentro ni afuera.

Ya Eduardo Muslip había hablado de que los elementos determinantes de las identidades en Copi eran aquellos más relacionados con su dimensión formal, más específicamente de su apariencia, como si los cambios o metamorfosis de la identidad, haciendo una analogía con la semiótica, ocurriesen más bien en el "significante" antes que en el "significado", según las mismas palabras de este crítico (Muslip 2007: 63)².

\footnotetext{
82 Así lo explica Muslip: "Los procesos de transformación en el terreno de lo sexual-genérico pueden también comprenderse bajo la categoría de metamorfosis. La idea de metamorfosis subraya el aspecto formal, 'morfológico', como la palabra misma lo indica, del cambio: lo importante es la alteración radical de la apariencia, lo que sería señal también de un cambio a nivel de 'sustancia', aunque la continuidad o la modificación a nivel de lo no observable no queda determinada. En última instancia, en la idea de metamorfosis hay cambio de aspecto, y puede discutirse si hay o no cambio a otros niveles; lo contrario es imposible, es decir, aunque se suponga un cambio a un nivel 'profundo', no hay metamorfosis si no se actualiza un cambio radical en la apariencia, la forma. Puede hacerse una analogía en términos semióticos y afirmarse que la idea de metamorfosis pone un énfasis en el nivel del significante y no del significado; el sentido se determinará en última instancia a partir del cambio en los aspectos materialmente observables del signo. En este punto, las transformaciones a nivel de sexo-género en el mundo dramático de Copi
} 
Y por eso es que, correlativamente, implantes, cirugías, prótesis, bisturíes, desmembramientos, inyecciones, entre otros objetos y acciones, son de circulación común en la obra de Copi (Muslip 2007: 63).

Esta importancia dada en la obra de Copi a lo material ha sido puesta de manifiesto por otras lecturas críticas además de la de Muslip, y sobre algunas de las cuales ya nos hemos detenido en otros capítulos. En una nota al pie en un texto de Alberto Giordano y Judith Podlubne dedicado a los escritores argentinos "extraterritoriales", estos dos críticos mencionan a Copi, y hablan de la presencia, en su obra, de un "efecto de superficie (psicológica, filosófica o de cualquier clase)" (Podlubne y Giordano 2000: 383n).

La escena de Le bal des folles que acabamos de comentar forma parte de una constelación de elementos "superficiales", y que se despliegan a lo largo de la mayoría de sus obras; en el caso específico de Le bal des folles, esta transformación material a partir de la superficie puede verse en los cambios que se van efectuando sobre el cuerpo de Pietro, que culmina en el momento en que el personaje de Copi llega a su corazón con la mano. Además, como se ha expuesto más arriba, la mutilación de Jean-Pierre (en la escena sadomasoquista) se lleva a cabo directamente con herramientas de trabajo.

\footnotetext{
siguen la misma lógica: el travestismo (el cambio de la identidad sexual a través de los signos construidos por maquillaje e indumentaria), el transformismo (el cambio en lo exterior que reserva la "nueva identidad" al terreno de la actuación teatral), la transexualidad (el cambio de identidad sexual a partir de cirugías) apuntan a poner énfasis en lo morfológico, propone la lógica de la metamorfosis; el cambio en los signos, esto es, en lo observable, lo comunicable, es lo central: en suma, éstos son los lugares donde radica la identidad. Y se asume de esta manera la identidad de género como una construcción en la que se eliminan los aspectos 'esenciales' para basarse en una serie de signos (desde los más 'volátiles' que aportan los cosméticos hasta el cambio de la 'forma' de partes del cuerpo). Incluso aspectos que también pueden ser considerados como construidos culturalmente, como aspectos psicológicos de la inscripción en lo sexual y genérico, quedan en el terreno de lo fantasmal" (Muslip 2007: 63-64).
} 
"Copi nos muestra personajes que oscilan entre el cartón y la carne", dice Rosenzvaig (2003: 118); aludiendo a esa especie de doble inflación que encontramos en sus obras: por un lado, la importancia extrema que adquiere lo superficial como determinante de las identidades (teniendo su epítome en el travestismo), y también, por el otro lado, el gran peso puesto sobre los cuerpos, la carne, y con ellos en la decadencia y la podredumbre, los humores y los líquidos vitales; así, dice Rosenzvaig refiriéndose a esta escena de Le bal des folles que estamos comentando: "El narrador protagonista Copi disecciona el cuerpo de su perseguidor, aparecen todas las deyecciones posibles, no por el gusto de exhibirlas sino para mostrarnos la fragilidad de la condición humana: creemos estar escondidos dentro del cuerpo cuando en realidad estamos perdidos en él. [...] Las deyecciones, los fluidos, los cortes y hasta la antropofagia harán imposible encontrar aquello perdido para siempre: la identidad" (Rosenzvaig 2003: 68-69). Pero la antropofagia a la que alude este crítico corresponde a la obra Cachafaz, que se abordará en el capítulo siguiente. 


\section{CAPÍTULO 9}

\section{Los hombres de la literatura argentina}

\subsection{Sobre los roles}

Ya se ha hablado, en el capítulo 6 de este trabajo, acerca de los vínculos estéticos que Copi tiene con Jean Genet. Refiriéndose al segundo, Anne Ubersfeld nos decía que "[t]odo el teatro de Genet descansa sobre [la] transformación de los personajes en roles” (Ubersfeld 1989: 107). El rol es, para Ubersfeld, "una de las mediaciones que permiten pasar de un 'código' actancial abstracto a las determinaciones concretas del texto (personajes, objetos)" (81). Podría decirse que Copi comparte esa característica con Genet, ya que todos sus personajes tienen cierta teatralidad que los conforma, como ya se ha hablado en otros capítulos.

Ya nos hemos referido antes a cómo, para Copi, los hombres heterosexuales (como los homosexuales, o las mujeres) son como "personajes de Arlequín", tal como lo ponía de manifiesto al ser entrevistado (Tcherkaski 1998: 51). Justamente al mundo de la Comedia del Arte es al que se referirá Anne Ubersfeld para ejemplificar esta cuestión; según ella, "en la Comedia del Arte todos los actores son roles, determinados por una función impuesta por el código" 83 (Ubersfeld 1989: 81).

\footnotetext{
83 "Arlequín tiene un comportamiento funcional previsible, no alterable. En el circo, el Augusto es un rol codificado. En una ceremonia religiosa los roles son desempeñados (o pueden serlo) por diversos actores (un cardenal, un obispo o hasta un humilde cura rural pueden decir la misa o administrar los sacramentos). Este sentido está próximo al sentido tradicional del rol (codificado) en el teatro [...]. El Matamoros no es un actor sino un rol, aunque venga definido por rasgos diferenciales aún más precisos. Hablando con propiedad, un rol sólo puede darse en un relaro rígidamente codificado (ceremonia religiosa o forma de teatro muy regulada). Así, los personajes de la comedia clásica no son propiamente actores sino roles: el padre Noble (la Barba), la joven doncella, el traidor, el galán, el indiano, el gracioso [...]” (Ubersfeld 1989: 81). Y, por otro lado, debemos aclarar que la noción de "actor" para Ubersfeld no es privativa del teatro, se
} 
Pero Copi no sólo toma esos "personajes de Arlequín" que para él son los hombres (y las mujeres, y los homosexuales, entre otros), sino también subgéneros artísticos con una tradición ya consolidada, y que por lo tanto ya traen incorporados consigo mismos muchos de sus roles típicos, pero que son transformados. Esto lo lleva a cabo a partir de la exageración o, más específicamente, de la parodia. Si hay o no hay parodia en Copi es una discusión que debería llevarse a cabo, y que otros ya han comenzado ${ }^{84}$, pero que excede los propósitos de este trabajo. Conservemos por ahora la explicación de Alain Satgé, para quien "Copi se apoya deliberadamente en los estereotipos de los géneros [...]" (Tcherkaski 1998: 151); cabe aclarar que los géneros a los que se refiere Satgé son los géneros "considerados menores (folletines, novelas policiales, ciencia ficción de clase B)" (Tcherkaski 1998: 151); debería agregarse, aquí, que no toma solamente esos subgéneros que menciona Satgé; también toma elementos del teatro, de formas teatrales conocidas, y no necesariamente, o no en todos los casos, "menores". Entonces, siguiendo a Satgé, digamos que Copi "se apoya" en los estereotipos de esos géneros, y trabaja con ellos. ${ }^{85} \mathrm{En}$ muchas de sus piezas teatrales Copi toma formas populares del teatro tradicional, algo que fue común en la Francia de los años 70.

El teatro en los 70 en Francia no fue un conjunto de tendencias unitarias, pero si pudiéramos aislar algunos de de sus rasgos, uno de ellos sería, en algunos autores, el regreso a las "formas originarias del teatro popular" (Floeck 1994: 148). En la mayor parte de sus obras, Copi utilizará formas teatrales tradicionales (la farsa vodevilesca en L'homosexuel ou la

refiere al "actor" en el sentido de "actante" del relato, una "unidad lexicalizada' del relato literario o mítico" (Ubersfeld 1989: 77).

${ }^{84}$ Por ejemplo, José Amícola en su libro ya citado del año 2000.

${ }^{85}$ Para Ilse Logie (2005), Copi toma los "estilemas" de esos subgéneros, y hace comportarse sus obras de modo "sinecdóquico" con respecto a ellos. 
difficulté de s'exprimer, el auto sacramental en Les escaliers du Sacré Coeur, por ejemplo), pero cuya utilización las aleja del propósito original, exagerando sus características intrínsecas o poniendo en sus lugares a figuras inesperadas en el medio original, que dejan sin efecto la forma de funcionar de los subgéneros literarios sobre los que se apoyan. En un artículo de Olivier Neveux (2006) se analiza el trabajo que Copi lleva a cabo en La tour de la Défense (1978) sobre los códigos de la comedia de boulevard de principios del siglo XX; allí Copi realiza un cambio importante: en lugar de la prototípica pareja protagonista heterosexual, introduce una pareja homosexual, que a su vez es acompañada por una vecina que está constantemente bajo los efectos del ácido lisérgico, y que mata a su propia hija; también aparecen un árabe y una travesti; alrededor de todos ellos se desarrollan los triángulos amorosos y las tramas simultáneas y de enredos que caracterizan a este tipo de comedias. De esas comedias, La tour de la Défense también toma el ritmo, la construcción de la situación, el entorno burgués, entre otros elementos. Pero la forma en que Copi utiliza esos elementos establece una diferencia con el original, como subraya Neveux:

Il ne s'agit pas de plier des personnages "gays", minoritaires, à la structure du boulevard, de procéder dramaturgiquement à leur assimilation - mais bien d'outrer les enjeux du boulevard, de citer une citation sans modèle (autre que social). La parodie n'est pas caricature condescendante : elle ne cible pas le boulevard en tant que tel mais la somme d'artifices qui le justifient et le conditionnent politiquement. [...] Copi déplace les données initiales, charge significativement l' "original" de ce que la société hétéronormative et hygiéniste forclot: sexes et drogues (Neveux 2006). 
Así, al saturar la pieza de signos de la comedia de boulevard, se nos muestra el vacío "ontológico" que sostenía a este tipo de comedias (Neveux 2006). De esta manera, este subgénero teatral que "essentialise immanquablement un type de relation, hétérosexuelle, et normativise à cette aune les conduites amoureuses et érotiques" (Neveux 2006), es llevado al vértigo de su propio vacío.

Así como La tour de la Défense no constituiría un "teatro de boulevard gay", porque en ella no se trataría de asimilar pacíficamente las figuras disidentes dentro de la estructura heterosexual típica de este subgénero teatral (Neveux 2006), de un modo similar sucede con las piezas "argentinas" de Copi: Cachafaz y La sombra de Wenceslao. Al decir "argentinas" nos referimos al subgénero teatral con el que cada una de ellas dialoga, que es, en ambos casos, de proveniencia rioplatense, y que Copi conocía bien: en los siguientes apartados de este capítulo se verá la forma en que ese trabajo estético es llevado a cabo.

\subsection{Un tango bailado al revés}

En Cachafaz se ha señalado la presencia de dos subgéneros teatrales argentinos que son vecinos entre sí: el sainete y el grotesco criollos. En realidad, el sainete, representado por obras de autores como Alberto Vaccarezza (1886-1959), constituye una antesala de lo que vendrá después en el grotesco criollo, que se considera un género propiamente argentino. El sainete aún estaba apegado al modelo español de sainete "azarzuelado", y luego, tal como lo ven los críticos teatrales, evoluciona hacia el grotesco criollo, que será más sombrío y con perfil tragicómico. Si hablamos de esto, no es solamente para mostrar tal o cual influencia sobre Copi, sino porque ese binomio sainete-grotesco y su articulación se encuentran detrás de 
elementos de Cachafaz que conciernen al problema de la identidad, del género y del cuerpo.

Uno de los rasgos señalados por los críticos teatrales en relación con el grotesco criollo y su evolución desde el sainete es el pasaje desde el espacio "exterior" donde se desarrolla la acción del sainete, representado por la calle o por el patio del conventillo, hacia la interioridad propia del grotesco, representada por el desplazamiento del conflicto hacia las habitaciones interiores; este desplazamiento es el correlato de otro desplazamiento, que es hacia el interior del personaje. Ésa es al menos la lectura de David Viñas en su trabajo sobre el tema publicado originalmente en 1973 (Viñas 1997). Es el paso desde una dramaturgia que prioriza el caricaturismo, el costumbrismo y el humor más directo y "popular" que describía la vida de los inmigrantes en los ambientes de conventillo de principios del siglo $X X$, hacia un drama más sombrío e irónico, más introspectivo, y por eso es que, en ese sentido, como decíamos, se "interiorizaría"86. "Poco a poco", dice Beatriz Trastoy,

[...] se va perdiendo el inicial aire festivo y las piezas empiezan a asumir visos tragicómicos que, en una fase posterior, darán lugar al nuevo género que crearía Discépolo cuando, de la burla del cocoliche del gringo y de la representación de actitudes estereotipadas, se pasa a la preocupación por el individuo desarraigado que ve fracasar sus ilusiones de mágico enriquecimiento y toma conciencia de la inmovilidad social a la que está condenado (Trastoy 2009: 204).

\footnotetext{
${ }^{86}$ Esa interiorización se corresponde también, según lo ha explicado Viñas, con "el fracaso del proyecto inmigratorio propuesto por el liberalismo que llega a sus límites de conciencia posible hacia 1930" (Trastoy
} 2009: 207). 
Según Viñas, es el fracaso del proyecto inmigratorio el que determina el paso desde el sainete a la tensión tragicómica del grotesco de Armando Discépolo (1887-1981). Eso lleva a decir a Viñas que el grotesco es una especie de infierno del sainete, y de quien constituiría su forma "superior", dice el crítico, su "toma de conciencia" (Viñas 1997).

En un principio podría pensarse que Cachafaz (escrita durante la década de 1970 pero publicada y estrenada muchos años más tarde), una de las pocas obras que su autor escribiese en castellano, guarda relación con estos géneros "de conventillo", sobre todo en relación con la pobreza y la miseria que se vive en la realidad y de la que la conciencia del género empieza a advertir con la dramaturgia de Discépolo: pero no hay, en Copi, presencia del problema de la inmigración. La acción transcurre en una pieza del "conventillo del Medio Mundo" en Montevideo: la pareja que habita esa pieza está constituida por el guapo Cachafaz y la Raulito, de quien no se sabe muy bien su "identidad de género": como dice Link, podría ser "[...] una loca, o un travesti o un transexual" (Link 2005: 355): el texto es impreciso, ya que da informaciones contradictorias. Puede estar aludiendo también a La Raulito, aquel personaje famoso interpretado por Marilina Ross en el cine en 1975; además, "Raulito" podría remitir a "Raúl", el nombre real de Copi. 87

Esa pareja anómala organiza el universo de Cachafaz: los otros habitantes del conventillo (el coro de Vecinos y el de Vecinas) no rechazan el tipo de relación que llevan Cachafaz y la Raulito, "[...] que sigue, más allá de que se trate de dos hombres, los roles del ambiente y, puede decirse, de los rasgos genéricos del sainete", dice Muslip (2007: 53-54). Esta distribución de roles de género sexual está puesta en evidencia desde el

\footnotetext{
${ }^{87}$ Así como en la novela L'internationale argentine (1988), aparece la hija natural de Borges, llamada "Raula Borges".
} 
principio, en el que se ve a Raulito fregando el piso y manifiestando estar cansada/o de que Cachafaz esté tirado en la "catrera"; le exige que deje la holgazanería y vaya a trabajar para proveer; es Raulito quien se encarga, también, de zurcir los pantalones de Cachafaz, entre otras tareas que se mencionan. La distribución de roles también se ve cuando ambos personajes practican bailar un tango, danza en la que se escenifican los lugares tradicionales o prototípicos del hombre y de la mujer. De ese modo, esa pareja central de Raulito y Cachafaz remite, como señala Osvaldo Aguirre, a los orígenes del tango, que se bailaba entre hombres y excluía a las mujeres (Aguirre 2004). Por eso la Raulito dice que antes "ilas mujeres eran hombres!" (Copi 2002: 73).

En cuanto a la masculinidad de Cachafaz, ésta parece seguir los rasgos del macho estereotípico, según apunta Joanne Pol (Pol 2010: 148). Aun cuando su pareja sea un/a travesti, o un/a transexual, su rol de "hombre" en la relación estaría dado, según se desprende de lo dicho por Cachafaz en la obra, por ser el "penetrador" (Pol 2010:148).

El sainete no es, sin embargo, el único género literario presente en Cachafaz. Aparecen también la gauchesca, en la forma de sus versos, que responden a la sextina del Martín Fierro (Link: 2005: 352); de modo que allí encontramos otro subgénero asociado comúnmente a figuras masculinas; pero aunque se siga la métrica y el tipo de rima de la gauchesca, el tema y las palabras utilizadas desestabilizan, nuevamente, el subgénero que se está usando. El otro subgénero que aparece es la tragedia griega; a ésta la encontramos en la presencia de dos coros, uno de ellos compuesto por Vecinas, y otro por Vecinos. Y más adelante aparece, también, un coro de Ánimas. Pero Copi no es sistemático en su utilización de rasgos de los distintos géneros, ya que en algunos momentos parece retomar los temas, y en otros momentos la forma (la métrica o la rima). 
Así, uno de los temas que Copi recupera en esta obra, y que se asocia también con la gauchesca, es aquél que caracteriza a la tradición "sangrienta" vinculada con El matadero (1871) de Esteban Echeverría y La refalosa (1843) de Hilario Ascasubi, en cuanto al nexo que en ellas se lee entre sexo, política y violencia. Copi rescata, dice Muslip, "ese locus del matadero argentino y lo resemantiza" (Muslip 2007: 56). Es decir, aquí esa tradición sangrienta es retomada pero de otra forma: el pueblo (representado por Cachafaz y la Raulito), no espera a que un dictador le proporcione alimentos, sino que se encarga de obtenerlo él mismo matando a los policías que vienen a capturar a Cachafaz y organizando un matadero compuesto de esa carne humana, con la que saciarán el hambre del conventillo. Y "Los hígados", dice la Raulito, "los tiramos / para engordar a los gatos; / son ellos que devoramos / en tiempo de vacas flacas" (Copi 2002: 53). Justamente las "vacas gordas" de este país (que es Uruguay, pero también Argentina), parecen ser "flacas" ya que el pueblo tiene hambre. De esta manera, el espacio del matadero actual (en escena) remite a ese espacio extraescénico del matadero en el que Cachafaz trabajó en el pasado, según se dice en el texto. Entonces, como se decía más arriba, Copi retoma, en Cachafaz, la tradición "sangrienta" del Matadero pero la aúna con otro tipo de sensibilidad, más afín, como dice el ya citado Monteleone, al

[...] sarcasmo de la tradición del teatro rioplatense que va del centenario a los años treinta, incluyendo el de las figuras de la mujer [...] que estalla en el vínculo homosexual entre Cachafaz y la Raulito, y su deriva hacia un grotesco antropofágico que se vuelve tragedia bárbara. (Monteleone 2012) 
Si hay una presencia del grotesco en Cachafaz, podría verse, quizá, en ese canibalismo que, en las lecturas del grotesco criollo que hacen algunos críticos teatrales, alude a una sociedad que, desilusionada, "se devora a sí misma": Beatriz Trastoy, por ejemplo, habla de la "ley de la antropofagia" presente en algunos conflictos representados en este subgénero (Trastoy 2009: 208). Aquí, el "devorarse" que era figurado, se torna literal.

Y en este Matadero anómalo donde la carne es de humanos, también la pareja central es, como se decía al comienzo de este apartado, anómala en relación con ese lugar: “ $\mathrm{Y} Y$ si quise enamorarme / es porque en el Matadero / es la gloria del matrero / ser adorado de un puto!", dice Cachafaz (Copi 2002: 71). Joanne Pol interpreta que el uso de la mayúscula que hace Copi en la palabra "Matadero" confirmaría la inscripción de la obra en esa línea de reescritura de la tradición literaria "sangrienta", pero situando como protagonista una pareja en la cual uno de sus miembros es un/a travesti o un/a transexual. Como lo expone Alan Pauls, en una cita que trae la misma Joanne Pol:

\begin{abstract}
¿Qué hace Copi? ¿Parodia El matadero o lee el clásico demasiado bien, literalmente, diciendo todas las letras, lo que Esteban Echeverría -fundador del género patrio por excelencia: la pornocarnicería-, sólo podía decir entre líneas? No: Copi es el que viene después, el que llega tarde para hacer algo que parecía imposible: dar toda la vuelta y reírse de la parodia (Pauls citado por Pol 2010: 160).
\end{abstract}

Por ese "reírse", incluso de la parodia, es que Pol sugiere que en Cachafaz "the parody is queerly performed" (Pol 2010: 160). Cachafaz resulta, así, una lectura a contrapelo de ese clásico. 
El nuevo matadero organizado en el conventillo termina, sin embargo, cuando, sobre el final, mueren Cachafaz y la Raulito. Daniel Link sugiere que la muerte de los dos protagonistas al final, con su consiguiente imposibilidad de escapar de ese orden que es restaurado por el Estado, sirve para marcar ese componente trágico -cuando es muy común, en realidad, que los personajes de las obras de Copi, una vez muertos, puedan resucitar, como efectivamente ocurre en varios de sus textos (Link 2005: 357 ), tal como hemos comentado en momentos anteriores de esta tesis. Pero hasta que ocurre este desenlace "trágico", parece desarrollarse, en el espacio del conventillo, una sociedad utópica, en la que no hay hambre y en la que Raulito y Cachafaz son aceptados por la sociedad del lugar. Esa utopía, dice Muslip, es también lingüística; hay en la lengua usada por Copi un trabajo de deconstrucción; así, se dice en el texto: "en este juego no viven/ ni compadres ni compadras. / ¡Todos somos compadritos/ mujeres, hombres y chicos!/ ¡Los compadres son los ricos, / los curas y los milicos!” (Copi 2002: 42). "Por un lado", dice Muslip,

[...] Copi señala la asociación de significante en dos signos distintos como compadre y compadrito, y supone que esa asociación también tiene consecuencias en su significado: compadrito se transforma en el diminutivo de compadre, en lugar de ser simplemente un signo distinto. $Y$ esa diferencia supone la oposición entre oprimido y opresor: los compadritos son todos lo que no son "ricos, curas y milicos". Con esto, también disuelve el rasgo de significado de masculinidad intrínseco a compadrito: en tanto señala a los que están "abajo", pueden serlo hombres o mujeres o niños. El femenino de compadre, además, no es aquí comadre-que implica, además de géneros distintos, roles sociales 
muy diferentes- sino el neologismo de "compadra", para socavar también el rasgo de masculinidad propio de ese término (Muslip 2007: 31).

Algo similar puede decirse de la palabra "conventillo": "Esta casa no es un mundo / convento ni fortaleza" (Copi 2002: 42), o sea que no es un convento, sino un conventillo; no es una fortaleza, porque allí no entran "milicos", y además es el Conventillo del Medio Mundo, que se opondría, así, a "Mundo" (Muslip 2007: 31).

El conventillo, el interior, marca la diferencia con el Estado, representado por los "milicos", que vienen a ametrallar a Cachafaz y la Raulito. Desde afuera, los milicos gritan: "isi no abren en el minuto / aquí no queda ni un puto!" (Copi 2002: 68). El acto de "abrir" está asociado al aniquilamiento de los "putos" que hay en el interior, "abrir" implicaría la destrucción de esa utopía instaurada en el conventillo. En el capítulo 2 de esta tesis se habló acerca del "mundo homosexual", o "mundo gay", una conformación identitaria a la que las ficciones de Copi parecen poner en crisis; en ese capítulo citamos a Aira, cuando decía: "El mundillo gay es la escena que necesita Copi, y Copi es el artista que necesita esta escena para volverse drama, novela, mundo" (Aira 1991: 50). Ese juego entre "mundillo" y "mundo" es similar al que se puede hacer entre "convento" y "conventillo", o también entre "Mundo" y "Medio Mundo". Por un lado, Copi parece reconocer la comunidad utópica, compuesta por los marginados de la sociedad, que se instala en el interior del conventillo, pero por el otro nos muestra la inevitabilidad de su destrucción, de su catástrofe. Ya hemos comentado cómo La cité des rats parecía ser la repetición en "código cifrado" de La guerre des pédés (Amícola 2000: 86), porque en ambas esa división entre "interior" y "exterior", entre "mundillo" y "mundo" era quebrada, 
abierta a la deriva y al estallido: las ratas, esos animales abyectos, situados "afuera" de la sociedad", se convierten, luego del estallido del Mundo, en los únicos sobrevivientes, que flotan en la Île de la Cité, convertida en una especie de Arca de Noé que lleva la utopía dentro de sí misma. Por eso no es casual que, en un momento de Cachafaz, el personaje del Vigilante le diga a Raulito: "[...] a tu pardo te lo quito / te lo pongo a pan y a agua / adentro de un calabozo / o te lo meto en un pozo / en la isla de las ratas (Copi 2002: 20, subrayado mío). No sabemos a santo de qué el Vigilante menciona "la isla de las ratas"; quizá esto sea motivado, como otros versos de la pieza, por necesidades métricas y fónicas, pero de todos modos la mención no puede ser inocente. Como las ratas, los protagonistas de esta pieza de Copi se encuentran al margen de la sociedad y del estado, por eso no es un dato menor que, además de practicar una sexualidad disidente, lleven a cabo el canibalismo, esa acción que parece marcar un límite extremo para la civilización.

Ya sabemos, por un artículo ya citado de Stefano Casi (2008), que los espacios teatrales de Copi son también "espacios mentales" que se encuentran "bajo asedio" de un exterior amenazante. Y por otra parte, aparece la contraposición, tantas veces teorizada (por ejemplo por el feminismo) entre el espacio externo o social, y el espacio doméstico o interior, una separación que, según se ha teorizado, tiene que ver también con una separación de "roles de género" referidos a la mujer y al hombre. En esta obra, los roles asociados a hombre y mujer son burlados a partir de los roles que vienen codificados en los géneros teatrales "de conventillo": leídos a contrapelo, nos muestran una vez más la importancia que los espacios teatrales/mentales tienen en Copi, y también hasta qué punto los roles sociales son roles teatrales. El tango sería, así, la mejor metáfora de esta idea, aunque se trate de un tango bailado al revés. 
Pero, volviendo a esos dos espacios que se contraponen, cabría agregar que ambos entran en tensión con otro espacio al que se hace alusión constante en la pieza, el "Más allá", allí a donde las mujeres, representadas por el coro de Vecinas, no quieren dejar entrar a la Raulito, por ser "una mujer con bigotes" (Copi 2002: 64). Luego, cuando la tragedia anula la utopía, Raulito concluye que: "Ya no habrá más más allá! / ¡Ni mucho menos acá! / ¡No habrá tiempo ni memoria / ni lugar ni pozo ciego / donde nos recordarán!" (Copi, 2002: 73). Sólo quedan Raulito y Cachafaz en escena, muriendo por las balas de los policías quienes, finalmente, logran atravesar la puerta hacia el interior. "En Cachafaz, el adentro y el afuera (del conventillo y del Estado) se confunden, y es la policía ('los milicos') quienes marcan ese umbral" (Link 2005: 357).

Es difícil determinar hasta qué punto las diversas formas de teatro rioplatense influyen en la producción de Copi, que escribió esta obra en Francia en un contexto epocal muy diferente del original de estas obras. Además, esas formas de teatro aparecen combinadas con otros subgéneros literarios no estrictamente teatrales, como la gauchesca, de algunos de cuyos temas se lleva a cabo una resemantización, como acabamos de ver. La solución a la que apelan algunos críticos para definir una posible adscripción de Copi a los rasgos de esas dramaturgias de principios de siglo XX ha sido la de considerar a Cachafaz como un exponente del "neogrotesco" (Fontana 2003, Pol 2010). Así, la ya citada Joanne Pol dice que lo que distingue al grotesco del "neogrotesco" es la especificidad histórica del primero, el anclaje de la historia contada en la época (Pol 2010: 130). Según Pol, si bien Cachafaz entreteje elementos del sainete y del grotesco criollo, es sin embargo con la variante "neogrotesca" con quien mejor dialoga, ya que la pieza no alude a un momento específico en la 
historia (Pol 2010: 131). Más directo es el diálogo, como hemos visto, con El matadero.

Entonces, volvemos a decir, si hay una influencia de ese primer teatro argentino en las obras de Copi, ella podría hallarse, quizá, no sólo en los elementos que explícitamente remiten a esa tradición (como el conventillo o el hambre), sino también en ese carácter sarcástico que, como señalaba Monteleone, se desenvuelve en el teatro argentino desde el sainete (el patio exterior) hasta desembocar en el grotesco (la habitación interior), y en el que se introduce, también, la posibilidad de lo trágico (la tragedia griega).

\subsection{Gauchos sin territorio 88}

En la otra obra escrita en castellano, La sombra de Wenceslao, el subgénero argentino con el que se establece el diálogo es el drama rural de Florencio Sánchez; según el ya citado Osvaldo Aguirre (2004), "el argumento reelabora un tópico del teatro rioplatense: la disolución de una familia rural como consecuencia de una nueva coyuntura histórica”. En las obras de Florencio Sánchez, cuyos más conocidos exponentes de temática rural están constituidos por M'hijo el dotor (1903), La gringa (1904) y Barranca abajo (1905), se ponen en escena historias protagonizadas por familias rurales que, a principios del siglo $X X$, viven la crisis de los viejos valores relacionados con lo criollo y su declinación ante el cambio operado en la Argentina con el advenimiento del nuevo modelo agroexportador y la llegada de la inmigración, que aportará una nueva mano de obra al país; frente al teatro criollo anterior, que según el mismo Sánchez, padecía de "moreirización", representando a gauchos criminales que se enfrentan a la ley, en el nuevo drama se busca una figura del criollo que sea conciliadora,

\footnotetext{
${ }^{88}$ La noción de "gauchos sin territorio" o "desterritorializados" es tomada del artículo de Juan Pablo Luppi (2015).
} 
enfrentado a la coyuntura y a los cambios socioeconómicos, pero donde él aparece como un trabajador de la tierra, apegado a la misma, acompañado de su familia, y en interacción, muchas veces conflictiva, con los inmigrantes. David Viñas veía en las obras de Sánchez una realización ficcional de ideas del propio autor, que interpretaba la realidad argentina según el viejo esquema de análisis civilización/barbarie heredado de Sarmiento (Viñas 1996: 64). Así, en Sánchez, los conflictos aparecen detentados por pares de personajes que sostienen esos valores opuestos: criollo versus gringo, civilización versus barbarie, pero también, desde un punto de vista generacional, el conflicto se ve como un enfrentamiento entre, por un lado, los hijos, que son los portadores de las nuevas ideas, y, por el otro, los padres, que tratan de seguir sosteniendo los viejos valores; estas oposiciones se llevan también al enfrentamiento entre campo y ciudad, como se ve en M'hijo el dotor. Sobre el final de La gringa, sin embargo, se produce una síntesis, cuando los hijos de los criollos y de los gringos se casan, uniendo así las dos culturas.

Según el citado Osvaldo Aguirre, parecería que es Barranca abajo la obra donde Copi parece buscar su material. Tanto en ella como en otras obras de Sánchez, en Barranca abajo se cuenta, en tono trágico, la historia de un gaucho y su familia; en ella el gaucho es don Zoilo, que pierde sus terrenos debido a las acciones ilegales de unos hombres de negocios. Gracias a la relación amorosa que existe entre su hija Prudencia y un acaudalado estanciero, don Zoilo y su familia pueden permanecer en su estancia, a pesar de haberla perdido. Las mujeres se mostrarán constantemente disconformes con el nivel de vida que don Zoilo no puede darles, y tramarán un plan para huir a la ciudad. Esto se llevará a cabo finalmente, y conducirá a Zoilo a preparar su suicidio por medio de la horca. En La sombra de Wenceslao, nuevamente vemos manifestarse el humor 
para leer aviesamente los contenidos de la obra de Sánchez; el gaucho del título aparece, como dice Aguirre, representando al gaucho viejo que funda una familia, el patriarca, al cual sus hijos se oponen. Por un lado Lucho, uno de sus hijos, que vive en Buenos Aires estudiando Medicina; por el otro lado la China, que sueña con ir a la ciudad y ver teatro de revistas. Pero Wenceslao tiene, además de sus dos hijos y de su esposa Hortensia, otro hogar, otro rancho donde mantiene a otra mujer, Mecha, la cual le dio un hijo, Rogelio. Este hijo ilegítimo y la China, la hija legítima, están enamorados entre sí; cuando Wenceslao le dice a Rogelio que no puede casarse con la China porque son hermanos, Rogelio le dice que nadie está muy seguro de que él sea hijo suyo, que más bien sería hijo del viejo Largui, un gringo que "le arrastra el ala" a Mechita, la querida de Wenceslao, y que, al contrario de los inmigrantes representados por Sánchez, aquí aparece como un inútil y un blando.

Esta pieza no presenta, como otras de Copi, una revisión intensa de los componentes de la identidad sexual; no hay aquí representaciones de sexo-género disidentes, como las que se ven en Cachafaz o en otras obras. Por lo tanto no ha atraído demasiado la atención desde el punto de vista de las cuestiones de sexo-género; pero, como observa Eduardo Muslip, esta lectura sí podría hacerse, si consideramos que es el patriarcado, representado por Wenceslao ${ }^{89}$, el que es cuestionado por medio de la exageración y del humor, a través de su brutalidad, de su violencia y de su masculinidad exacerbadas hasta el límite de la sátira; según Muslip, en la pieza se asiste a una "crispación de la genitalidad"; y "la violación de las

\footnotetext{
89 Si bien ha habido diversas definiciones de "patriarcado", en su sentido original significaría, según Marta Amanda Fontenla, el "gobierno de los padres", y continúa: "[H]istóricamente el término ha sido utilizado para designar un tipo de organización social en el que la autoridad la ejerce el varón jefe de familia, dueño del patrimonio, del que formaban parte los hijos, la esposa, los esclavos y los bienes. La familia es, claro está, una de las instituciones básicas de este orden social" (Fontenla 2007: 256).
} 
restricciones de la sexualidad patriarcal a través del exceso [...] del suplemento" (Muslip 2007: 37) ${ }^{90}$. Esto posibilita, según Rosenzvaig, una "revisión de los "tópicos de la masculinidad" (Rosenzvaig 2003: 131). El "exceso" del que habla Muslip puede verse, por ejemplo, en la forma en que Wenceslao habla y se refiere a los demás. Por ejemplo, de su hijo Lucho, dice: "el tipo me salió marica" (Copi 2002: 78) porque que se fue a estudiar a Buenos Aires. Además, la forma en que Wenceslao trata a las mujeres y expresa su deseo por ellas es también violenta, exagerada y fuertemente machista: cuando está solo con Mecha y trata de sacarle la ropa, ella le dice que se detenga, porque el viejo Largui le pidió la mano, y él responde: "¡Qué mano ni qué mano! ¡Yo te rompo la concha!” (Copi 2002: 99); y luego: “¡Bajate el calzón, puta!” (99), y la amenaza con el rebenque. En realidad, Wenceslao está amenazando continuamente con "cagar a todos a rebencazos". Sin recurrir, como Cachafaz u otras obras, al recurso del travestismo, Copi muestra esa performatividad de género, esa repetición de actos que conforman la masculinidad asociada a los "roles de género"; muestra esto por medio del exceso y la desmesura que le son permitidos por el carácter hiperbólico del humor.

Que Copi en La sombra de Wenceslao y en Cachafaz aborde de esta manera peculiar el tema del gaucho y de su masculinidad obedece en gran medida al contexto de producción de estas obras, que no es Argentina, sino Francia a fines de la década de 1970. Como ya se ha comentado en el capítulo 2, Guy Hocquenghem hablaba en Le désir homosexuel acerca de la "polivocidad del deseo" (Hocquenghem 2009: 23), a la que el capitalismo

\footnotetext{
90 Así lo explica este autor: "la crispación de la genitalidad justamente no supone una propuesta de explicación y reducción del deseo sino en mostrar el exceso, el suplemento, que hay algo más y que eso se tiene que manifestar [...] en esos seres capaces de ternura y también de crimen, de canibalismo, de mutilación" (Muslip 2007: 57).
} 
intenta domesticar y de cómo la familia es la institución privilegiada en esa regulación del deseo. En La sombra de Wenceslao, la familia del gaucho y su moral patriarcal resultan desmanteladas por el desborde del deseo. En primer lugar encontramos el deseo sexual desbocado de Wenceslao, que, por supuesto, no se dejaba ver tan patentemente en gauchos como el Zoilo de Barranca abajo; pero también está el deseo de sus hijos, representados por la China y Rogelio, que siendo hermanos (aunque de distintas madres) se acoplan siguiendo su deseo y llegando, por ello, al incesto. Wenceslao enviuda de su mujer Hortensia, y ello lo conmueve y decide irse hacia el norte, hacia un sitio que poco tiene que ver con el ambiente rural de los dramas gauchos: las cataratas del Iguazú91. Se lleva para ello a su querida Mecha, y deja el casco de estancia para sus hijos. En las cataratas, Wenceslao cumple el destino del gaucho Zoilo de Barranca abajo, ahorcándose en una rama de árbol.

Por su parte sus hijos continúan con esta desterritorialización: la pareja de Rogelio y la China va a Buenos Aires; allí, la China conoce a un director de cine por el que traiciona a Rogelio; y en un tiroteo que se genera en un lugar público, ella muere alcanzada por las balas. La ciudad representa, así, la perdición literal de la gente del campo. No hay síntesis en Copi, como ocurría, por ejemplo, en el matrimonio final de La gringa de Sánchez: aquí, el gringo, Largui, no duda en abandonar su lugar de trabajo, siendo mantenido en un principio por la China y Rogelio; durante ese período, duerme continuamente en el catre. Luego parte en bicicleta a las cataratas del Iguazú, siguiendo a Mecha, que está con Wenceslao, el patriarca sin territorio. La descendencia, en quienes podría cifrarse la esperanza, también está, como en otras obras de Copi, negada; así, el bebé

\footnotetext{
${ }^{91}$ Juan Pablo Luppi observa que el traslado hacia esta geografía parece tener más relación con el "softcore local", que se podía ver en las películas que Isabel Sarli protagonizó en la década del 60 y cuya acción transcurría en esa zona, así como con un famoso spot publicitario de jabón, protagonizado por Susana Giménez (Luppi 2015: 21n).
} 
que tienen la China y Rogelio, muere porque la China coloca, accidentalmente, veneno para comadrejas en su mamadera.

Siguiendo con el espíritu de sus mejores piezas, en La sombra de Wenceslao Copi retoma temas del teatro tradicional y los resignifica. Así, aunque tome de Sánchez ese juego de oposiciones compuesto por los pares barbarie/civilización, padres/hijos, criollo/gringo, campo/ciudad, no lo hace acríticamente, sino que lo ridiculiza y lo desmantela. Los gauchos son, ellos también, "figuras de Arlequín" para el teatro de Copi.

\subsection{Nación kitsch}

Habiendo pasado revista a ese trabajo estético que Copi lleva a cabo con las figuras de varones argentinos de Cachafaz y de La sombra de Wenceslao, queda preguntarse qué observaciones podría deparar esto en relación con la "identidad nacional" de Copi, o, si se quiere, con los ecos que esta inestabilidad de género tiene en la conformación de la identidad nacional. Ya Eduardo Muslip en su tesis había hablado de que la identidad de sexo-género en Copi podría pensarse como una metáfora de la inestabilidad de la identidad en todos los demás planos (Muslip 2007: 64). Este crítico también ponía el acento en algo que sobre lo que se habló en el capítulo anterior de esta tesis, es decir, el hincapié que la estética de Copi hace sobre la representación de las "superficies", del "exterior", de la "apariencia", y la importancia de estas dimensiones en las configuraciones identitarias; en relación con esto, habíamos también comentado la idea de "efecto de superficie", esbozada en una nota al pie de un artículo escrito por Podlubne y Giordano. También habíamos mencionado las observaciones de José Amícola en torno a cierto regodeo en las "superficies" que caracteriza a los autores camp (entre quienes Amícola ubica no solo a Copi, sino también a Puig y Perlongher), representado por una presencia de los 
objetos costureriles o relacionados con la construcción del sujeto mujer. Pero además, y como se ha observado en otro momento de esta tesis, esta obsesión por la superficie se transmite al mundo que rodea a los personajes, en especial a los decorados. Pablo Gasparini, en un estudio sobre Copi y otros dos autores "transnacionales" (Witold Gombrowicz y Néstor Perlongher) aborda la cuestión de cómo el autor objeto de esta tesis trabaja en sus obras con el "kitsch" de "lo nacional", frente a lo cual lo grotesco aparece como un quiebre o salida ${ }^{92}$; uno de los textos que Gasparini analiza es el de La vie est un tango, donde aparece un personaje que remeda (u homenajea) a Natalio Botana, o sea el abuelo de Copi, dueño del diario Crítica; en la descripción del opulento salón de Lauro Bochinchola (tal es el nombre ficcional que Copi le adjudica a la versión de su abuelo en su delirante roman à clef) se encuentra un eco de una descripción que Pablo Neruda hiciese en una memoria de su visita a la casa de Botana; el abigarramiento de objetos lujosos recuerda de algún modo al de la casa de Charles Foster Kane, "el Ciudadano" de la película de Orson Welles de 1941 (quien también estuvo inspirado por un magnate real de los medios de comunicación, William Randolph Hearst). Para Gasparini, hay un nexo entre la descripción que hace Neruda y la que hace Copi en la ficción; a su vez esto se conecta con otros momentos descriptivos de sus obras; cito a Gasparini extensamente:

[...] Ilama poderosamente la atención cómo Neruda puede atisbar en la frívola fastuosidad de la biblioteca familiar de los Botana, cierta concepción degradadamente suntuosa de la cultura; y lo que es más curioso: que lo haga de una forma que evoca,

\footnotetext{
${ }^{92}$ Aquí Gasparini hablará de "lo grotesco" en el sentido que le daba Wolfgang Kayser en su libro pionero sobre el tema: Das Groteske. Seine Gestaltung in Malerei und Dichtung (1957).
} 
anacrónicamente, las delirantes y rutilantes descripciones del mismo Copi. [...] De hecho, "las jaulas de faisanes de todos los colores", las exuberantes y exóticas "pieles de pantera cosidas una a otra" y la biblioteca repleta de esos libros no menos exóticos libros no tanto para ser leídos sino para ser exhibidos y mostrar la marca misma de la opulencia- nos recuerdan frases como "llevaba una minifalda de piel de víbora y zapatos dorados" o cualquier otra que no dudaríamos en atribuir al propio Copi. [...] Si el kitsch puede definirse como la búsqueda de un efecto bello que moviliza diversas estrategias de seducción, o más bien como una tentativa de reenviar una imagen embellecida de la realidad [...], no dudaríamos en señalar en el lujo culturalmente barato de la biblioteca de Botana o en el brillo de utilería de la minifalda de la frase de Copi, aquel simulacro de belleza que caracteriza a esta categoría estética. [...] En los relatos de Copi, ese kitsch se evidencia anecdóticamente en las rutilantes prendas de sus personajes travestis, o, a veces, en las aparatosas descripciones de escenarios de una desenfrenada, exuberante y opulenta modernidad (por ejemplo la oficina de Silberman en La vida es un tango). (Gasparini 2006).

Luego de esto, Gasparini nos explica cómo Copi quiebra el kitsch a partir de lo grotesco que esas mismas descripciones contienen, al mostrar la pretenciosidad de esos ambientes fastuosos. Hay entonces en Copi una presencia de esos elementos "decorativos" (muchas veces opulentos) que forman parte más de sus novelas y cuentos que de su teatro. Ya hemos visto cómo la profusión de decorados y utilería en la narrativa de Copi parece suplir la "visualidad" propia del teatro: como planteábamos en el 
capítulo anterior, en el teatro vemos lo que se "pone en escena", pero en la ficción narrativa será necesaria la descripción y la presencia visual de elementos que pongan el acento en las superficies, en lo material o, insistimos, en la utilería escénica y en el decorado, apareciendo este último como artificiosamente plástico; Amícola cita un fragmento de La guerre des pédés donde se describe un "utópico pasaje de ciencia ficción en su propia irrisión" (2000: 86); en el pasaje Copi decribe una "cumbre", que "estaba cubierta de plástico blanco que imitaba a las nieves eternas" (86). En ese pasaje de Copi se ve la conciencia de ese plástico decorativo y kitsch, del que Copi se burla pero que reconduce nuevamente a ese intento constante de poner de manifiesto las "superficies". Patricio Pron llama la atención sobre el hecho de que en algunas de las narraciones de Copi se pone mucho el acento en las descripciones de vestuario, algo que el género narrativo necesita para construir su visualización la cual, como se veía en ese comentario del narrador protagonista Copi sobre el que ya hemos hablado en el capítulo anterior -y al que Pron también cita-, es importante para los personajes travestis y su percepción (Pron 2007: 67).

Esto lo podemos vincular con la insistencia de Copi en mostrar lo que Gasparini llama el "kitsch nacional" a partir de, por ejemplo, los objetos que dan "color local", que, según Muslip, aparecen con una profusión que, en su opinión, des-argentiniza a los textos: esto Muslip lo ve especialmente en La sombra de Wenceslao:

Se encuentra en La sombra de Wenceslao una saturación de referencias locales: en el campo hay ombúes, mate dulce y mate amargo, pericones, alpargatas, loros, carretas, ranchos, langostas; en Buenos Aires, tenemos canillitas, humedad y smog, el Congreso, el Centro, bulines, cinematógrafos, Gardel, vida 
nocturna, tapados de nutria y de zorro, cigarrillos Chesterfield, cocaína, productores de cine, prostitución, militares y políticos corruptos, asonadas militares: se forma un campo semántico que remite directamente al Buenos Aires anterior a la aparición del peronismo. En este sentido, el texto no es "histórico" sino que produce, como diría Jameson [...] un "efecto de pasado", un conjunto de clisés que arman un "escenario de época". La crítica insiste en señalar todo lo que hay de "argentino" en Copi, pero esta profusión de alusiones, bajo cierta perspectiva, lo "desargentiniza"; si pensamos en la tan conocida y repetida afirmación de Borges en "El escritor argentino y la tradición" [...] respecto de que la prueba de que el Corán es árabe está en la ausencia de camellos, concluiremos que Copi no se muestra "argentino" justamente por la necesidad de remarcar la "argentinidad" a través de la profusión de referencias locales. Sobre el modo en que esta consigna borgiana rigió la escritura argentina del siglo $\mathrm{XX}$, estimulando ciertas formas de ficción pero también censurando otras, forzando a un tipo de realismo del que autores como Copi consiguen desembarazarse [...] (Muslip 2007: 152-153)

La idea de Muslip es que, contrariamente a las instrucciones de Borges, en el Corán de Copi habría muchísimos camellos. Ahora bien, esto nos podría hacer pensar en que esos elementos locales que aparecen con profusión son también elementos "plásticos", de utilería, casi como la hombría asociada a los machos argentinos del tango y de la gauchesca, que son deconstruidos por Copi, sea por una instalación a contrapelo en ellos (Cachafaz), sea por un exceso deformante a partir de sus estereotipos (La sombra de Wenceslao): "Copi se sirve de aquello que los argentinos 
exportamos a Europa desde 1920 y más aún en la actualidad; lo toma para ponerlo al descubierto y en ridículo: el tango y el compadrito" dice Rosenzvaig (2003: 131). Ahora bien, si tenemos en cuenta que el tango y el compadrito son una parte de aquellos componentes culturales que la Argentina exporta a Europa desde hace mucho, ¿no puede decirse lo mismo de Eva Perón? Eva también forma parte de nuestra "simbología nacional argentina for export", como define Verónica Delgado al uso que en Copi se hace de ciertas representaciones de lo "nacional" (Delgado 1996: 258-259).

Ahora bien, esos objetos con los que el camp trabaja, más allá de que en su origen se trate de elementos relacionados con lo cosmético y lo vestimentario, tienen una relación con algo de eso que Gasparini ha llamado el "kitsch nacional"; quizá la muestra más flagrante se encuentre en la novela L'internationale argentine (1988). Las "odas a la patria" escritas por "Darío Copi", ese personaje poeta que puede pensarse como un trasunto del Carlos Argentino Daneri de Borges ${ }^{93}$, son efectivamente poemas que trabajan con los estereotipos de lo nacional ("L'ode à la Cordillère", "Le Soleil rouge des pampas"); pero además, en la novela se despliegan un sinnúmero de elementos relacionados con ese kitsch, y con los aspectos superficiales como determinantes de las identidades, y no sólo de la identidad argentina; por ejemplo, en un momento de esta obra, el personaje del embajador ruso (apellidado Zhivago) le cuenta a Darío Copi que, en París, cada embajador tiene como mascota el animal más asociado al imaginario de su país de origen; así, Zhivago le cuenta que él tiene un oso, y el embajador argentino un puma, el de Marruecos un camello, el de la India un elefante y el de Brasil una anaconda (Copi 1988: 100). Lo estereotípico aparece tomado en una forma que no puede considerarse

\footnotetext{
${ }^{93}$ Tal como lo sugiere Amícola en su artículo del año 2008.
} 
puramente autóctono, sino que viene filtrado por esa "simbología for export": por eso Copi utiliza tanto los discursos exotizantes; Copi parte de esa deformación inicial del exotismo. Como las ratas de La cité des rats, Copi parte de los restos, los desechos, y recicla, reconvierte, transforma. Aunque no haya un planteamiento en torno a la sexualidad, en L'internationale argentine encontramos, sin embargo, estos significantes de la cultura exacerbados: aunque no haya aquí un/a travesti para ponerlos en escena, de todos modos sigue habiendo un procedimiento que el recurso del travestismo comparte con el humor: la hipérbole a partir de los elementos superficiales que conforman la identidad:

Creo que la insistencia de Copi por mostrar el falso idilio de una esperanza de identidad, esa tan infrecuente reducción del sueño común al juego frívolo del kitsch, es su singular manera de inscribirse de algún modo en la tradición argentina, la forma que el inmigrante escritor bilingüe Copi ha encontrado para poder ser leído en aquel país que le ha adjudicado "un pasaporte de cuero de vaca legítimo, azul”. (Gasparini 2006).

Aquí Gasparini está haciendo alusión a una respuesta de Copi en la entrevista con Tcherkaski: "Yo no tengo nacionalidad; la nacionalidad está en el pasaporte y eso lo conservo siempre; tengo el pasaporte de cuero de vaca legítimo, azul; lo lustro como lustro los zapatos" (Tcherkaski 1998: 73). Para Copi, entonces, ser argentino es tan solo tener ese objeto: la identidad aparece reducida a los elementos superficiales que construyen nuestro ser nacional, como si lo kitsch fuese la materialización de ese sueño compartido de la "nacionalidad", pero ya alejado de toda determinación a partir de una esencia. Este despliegue de objetos de lo nacional está, entonces, en un 
nivel similar a otros objetos que aparecen en la obra de Copi, pensados desde su lado más cristalizado, como las manifestaciones que vemos en $L a$ sombra de Wenceslao: el mate dulce, las alpargatas, pero también, y como hemos visto en los anteriores apartados de este capítulo, y como decía Rosenzvaig, las mismas figuras del gaucho o del compadrito: es decir, el macho argentino.

En un cuento de Copi publicado en 1983, "La Déification de JeanRémy de la Salle" se habla, a través de una especie de discurso etnográfico de una tribu de indios del sur de Argentina, "Les Boludos" (en español en el original), que tienen la particularidad de que sus testículos son muy grandes, al punto que practican un orificio en sus pantalones para que les entren en ellos. Todavía más, ellos pintan sus testículos de color cuando van a la guerra, y a su vez se alimentan de huevos de cóndor y leche de vicuña. Esos huevos desmesurados de "Les Boludos" (que el narrador relata con su discurso exotista) podrían considerarse, nuevamente, como esos "excesos", esos "suplementos", esas "crispaciones de la genitalidad" que señalaba Muslip en la masculinidad de Wenceslao. Este procedimiento hiperbólico, como hemos visto, se encuentra en muchas obras de Copi; en este cuento, como en otros momentos de su obra, Copi materializa el estereotipo, lo vuelve literal.

O sea que, si bien el travestismo es muy importante por varias razones, una de las más relevante se encuentra en que este fenómeno aparece como un imán que reúne a su alrededor varias de las obsesiones de Copi, como la identidad en general, y también la inflación hiperbólica que se le da a los aspectos superficiales de la identidad; todo eso es aquí proyectado sobre las identidades masculinas, que también se construyen, en parte, siguiendo un estereotipo cristalizado de la masculinidad, una discursividad que se ha convertido en un material, específicamente un 
material escénico (estemos o no en el teatro): los personajes de Copi, como los de Genet, también se convierten en roles (sostenidos por un disfraz). 


\section{CAPÍTULO 10}

\section{Conclusiones}

Después de haber hablado sobre el tema abordado en el capítulo anterior, es decir, la forma en que es tratado el tema de la identidad nacional en Copi, resulta inevitable volver a hacerse una pregunta que se nos aparecía en la Introducción de este trabajo. Si el sujeto que vemos figurado en Copi se caracteriza por estar "fuera de sí" (como decía Pustianaz en su texto de 2008); ¿cómo se puede decir que Copi sea argentino, latinoamericano o francés? Si bien desde el título de esta tesis se ha hablado de "fronteras de la teatralidad" (utilizando el término "fronteras" de un modo parecido a como lo usaba Barbéris), en realidad podría hablarse también de que las "fronteras de la nación" aparecen como uno de los temas posibles en Copi, como un constructo, vinculado con la identidad, que se muestra en proceso de desacomodamiento. Ya desde Eva Perón, Copi pone en relación lo "nacional" con lo teatral y la teatralidad, como si una de las encarnaciones más importantes de la "simbología nacional" fuera el resultado de un proceso de teatralización o de travestismo. Este último, como ya Rosenzvaig (2003) ponía de manifiesto, se muestra como el epifenómeno de esta idea que parece recorrer toda la obra de Copi. La frontera o el umbral principal en esta teatralidad parece ser el disfraz, que se manifiesta como un enclave principal de la estética del autor; y, en relación estrecha con el disfraz, encontramos también el cuerpo, que en Copi parece entenderse de una forma equivalente; el cuerpo puede ser, directamente, vestimenta o disfraz. De este modo, los atributos de la identidad, e incluso el cuerpo que los sostiene, son pensados como una utilería teatral. Y 
"encarnar un papel" (o un "rol" teatral) es literalmente "hacerlo carne", se vuelve parte del cuerpo; esa es la forma en que Copi sutura la distancia que, podía suponerse, existía originalmente entre travestismo y transexualidad; desde el disfraz, la superficie, hacia el cuerpo, a la carne misma, hasta llegar a una síntesis en lo que hoy en día podríamos denominar como "transgenerismo".

Existe además otra forma en que se puede ver, en Copi, la importancia del teatro y de la teatralidad, y ella se da, como hemos comentado en el capítulo 7, a partir de la noción de "espacio". Desde que los críticos empezaron a hablar de las obras de este autor se puso de manifiesto que el espacio teatral parece ser una especie de "espacio mental", o, para decirlo de otro modo, que se trata de una representación de la "mente". Como hemos visto, quizá el ejemplo más extremo de esta idea es la pieza teatral Loretta Strong, donde la frontera entre el interior y el exterior del sujeto era trastocada, ya que ese límite desaparecía para dar paso a una mutua invasión entre ambos espacios. En una cita que ya comentamos en la Introducción, Eduardo Muslip mencionaba una lectura del crítico teatral francés Michel Corvin, cuando decía que en la obra de Copi se asistía a una "objetivación de las pulsiones", "en la forma de seres concretos"; Corvin extraía de esto la conclusión de que Copi podría ser un "heredero de Artaud" (Muslip 2007: 142), cosa con la que Copi habría estado en desacuerdo ya que, ante una pregunta en la que Tcherkaski sugiere la posible relación con las ideas del dramaturgo y poeta surrealista, Copi responde que nunca lo ha leído (Tcherkaski 1998: 29 ).

Ya habíamos mencionado a Artaud en la Introducción de esta tesis, a partir de apreciaciones críticas que, tomando en cuenta sus teorizaciones, lo definían como un portaestandarte de cierta tendencia de "reteatralización" del teatro occidental, considerando a ésta como una especie de marca 
distintiva que ha definido de modo intenso una gran parte de este arte en el siglo XX. Es difícil saber si el teatro en el que pensaba Artaud ha llegado, alguna vez, a su plena realización, ya que ha habido distintas interpretaciones o puestas en práctica de las ideas que el escritor francés defendiera en sus textos sobre el tema. Podría pensarse la relación de Copi con Artaud en cuanto a que en la obra de nuestro autor asistimos, como hemos venido hablando, a una especie de teatralidad "pura", en el sentido que le da el mismo Lavelli, cuando dice: "La théâtralité de Copi est extrême, pure, toujours magnifiée par une invention dramaturgique à la fois complexe et mathèmatique" (Lavelli citado en González Doreste 1994: 386). En otro texto, Armando Llamas, hablando de Les quattre jumelles, dirá: "Desembarazada del peso de la poesía, del psicologismo, del didactismo, de la interioridad, [es] una de las grandes piezas de teatro de nuestro tiempo, irreductible, un verdadero teatro de la crueldad que habría cumplido de una vez por todas, sobrepasándolas, las propuestas de Antonin Artaud" (Llamas citado por Tambascio 1997: 111). Llamas está hablando, justamente, de una de las obras de Copi donde más se ve ese anulamiento del "psicologismo", del "didactismo", de la "interioridad", ya que, como hemos visto en el capítulo 7, asistíamos en ella a una continua repetición del crimen al infinito, en un vaciamiento progresivo del peso trágico de la muerte, en esa entropía que las acciones de las gemelas protagonistas vehiculizan, hasta el "aplanamiento actancial", es decir, que se trata del fenómeno del teatro de Copi condensado en una sola pieza: así, ésa sería, quizá, la "teatralidad pura" que vería Lavelli en Copi, esa reducción de los personajes a la materialidad de sus cuerpos y sus actos: ése podría ser, probablemente, el teatro "cruel" de Copi, ya que es un teatro desembarazado de esos elementos que en la enumeración del citado 
Llamas remiten a todo aquello que Artaud veía como los lastres del teatro occidental.

Visto y considerando la originalidad del teatro de Copi, es inevitable que surja siempre esa pregunta sobre su adscripción a alguna corriente artística. En la última década, como hemos visto, las lecturas de su obra han tratado de vincularlo, muchas veces, con algo que podríamos llamar "teatro queer", concepto que, como hemos dicho, responde a un marco de observación más contemporáneo a nosotros que al mismo Copi, aunque sin duda resulta inevitable trazar esa relación. En una recopilación argentina reciente titulada Teatro queer (2013), el compilador (y prologuista) Ezequiel Obregón dice que la obra de Copi podría pensarse como un antecedente posible de este tipo de teatro, que se asocia con las ideas actuales en torno de lo queer. Pero Obregón hace una buena aclaración al explicar qué es, para él, el teatro queer, o qué es para él el trazo que lo define actualmente, y dice: "El ingreso de lo queer en el teatro de nuestra época se define por el desprendimiento de la representación de las identidades sexuales de la ancilaridad en el hecho teatral (ya sea para negarlas o para defenderlas). Las subjetividades queers, entonces, dejan de ser un problema en el sentido de que ya no ejemplifican o dan cuenta de un vínculo entre lo social y lo artístico. Se transforman, en consecuencia, en la propia materia con la que el teatrista construye su poética" (Obregón 2013: 7).

Algo parecido puede decirse de las subjetividades que aparecen en Copi, que no constituyen un "problema", sino que forman parte de su poética, casi como un material, $y$, sobre todo, de un material que articula esa poética como un todo. El travestismo escénico, como hemos visto, aparece como una emergencia que, casi como un corolario, no se podría evitar en la obra de nuestro autor, como si fuese la manifestación escénica de algo que ya está ocurriendo, también, en el plano de la fábula. Y si su 
obra es queer, esto será porque en ella se pone el acento en algo que ese tipo de pensamiento tuvo siempre en cuenta: el cuerpo. Para Copi es ahí, en el cuerpo, en donde todas las mutaciones son posibles, donde se producen los "pasajes", como los denomina Aira: "una proliferación de pasajes: entre los sexos, entre lo humano y lo animal, entre el niño y el adulto, entre la vida y la muerte" (Aira 1991: 14).

Esos pasajes que enumera Aira se deben, en gran parte, a la velocidad de ese mundo en tránsito, que no da tiempo al acomodamiento; no hay estabilidad en Copi, y ni siquiera la muerte detiene el movimiento: y por eso, en algunas de sus obras se asiste a la resurrección y al recomienzo luego de la muerte, como se podía ver en las continuas muertes de Les quattre jumelles, donde la catarsis de la tragedia era imposible, porque ésta se alcanzaba desde el comienzo, y a partir de allí se repetía, una y otra vez, produciéndose, así, ese "pasaje", casi sin mediación, "entre la vida y la muerte".

Otro "pasaje" que Aira enumera es "entre el animal y el hombre". Ya hemos hablado de las marionetas de rata que Copi usó en su teatro, así como de los disfraces de animales, y que podían ser una posibilidad identitaria dentro de ese tránsito mutador continuo. Los animales, entonces, son un devenir posible en esa transformación que, como señalaba Muslip en una cita que se utilizó en el capítulo 1, sería más bien una "metamorfosis". En el mencionado capítulo 1, hablamos de que en Copi encontrábamos un mundo protagonizado por sujetos considerados "nohegemónicos". En ese capítulo se había hablado acerca de cómo la construcción de un trasfondo de abyección está directamente relacionada con la conformación de la subjetividad. Desde el inicio de su producción, Copi da cabida a los animales, como cuando dibujaba perros, pollos y caracoles que venían a hablar con la Mujer Sentada, o cuando él mismo se 
transvestía en diversos animales en escena; la de los animales es una presencia que, tal como nos decía Muslip en un fragmento de otro texto que ya citamos, nos recuerda que "pertenecemos a una especie más, con pulsiones tan básicas como las de las otras" (Muslip 2009b). Si tal como decíamos al hablar de Le Frigo, el disfraz puede alojar, como una de sus posibilidades de agenciamiento, el de una rata, esto es porque el tránsito y la aceleración propios de las acciones de Copi llevarán, inevitablemente, a esa metamorfosis, como cuando Irina, de L'homosexuel ou la difficulté de s'exprimer, va sufriendo una descomposición donde su cuerpo y su identidad mutarán hasta volverse un puro cuerpo sin voz, en una especie de estado animal, no humano, casi de "invertebrado". Al caer las fronteras de la subjetividad clásica, aquello que, en la conformación del sujeto, había sido abyectado, vuelve para trastocar las fronteras. Y lo animal, entonces, es una de las formas en que, en el universo de este autor, regresa todo aquello que es excluido en la conformación de la subjetividad, pero que a la vez perteneció, en algún momento, a ella.

Por eso, en este universo literario, los animales se encuentran cerca de los humanos, y en muchas ocasiones mantienen un vínculo estrecho con ellos. Quizá el animal más especial en su universo es la rata, la cual se particulariza por la relación de dependencia con los desechos del mundo de los Hombres, y a la vez por su ubicación en los estratos más bajos y abyectos de la jerarquía de los seres vivos. En la novela La cité des rats, estos roedores son directamente los protagonistas, están dotados de habla y terminan protagonizando la revolución que pone en escena la novela; después del Apocalipsis, de la destrucción del mundo, ellas sobreviven, junto con los demás excluidos de la sociedad (presos, locos, otros animales). Así, se embarcan en la isla de la Cité, para comenzar un periplo por el mundo en el cual son abolidas todas las fronteras de la ciudadanía. 
Copi toma como tema la perspectiva de los excluidos, de los marginales, de aquellos que son expulsados de la sociedad para que ésta pueda funcionar. Por eso La cité des rats podría leerse como una "síntesis filosófica" de todo el resto de la obra de Copi, en el sentido de que resume y da forma ficcional a su concepción del sujeto y de la identidad. Por un lado, se trata de una novela atípica, porque en ella no encontramos la presencia de una sexualidad disidente, pero, por el otro lado, sí encontramos la perspectiva de lo que podríamos considerar como la disidencia de la subjetividad humana, algo que veíamos muy bien ficcionalizado en sus figuras teatrales.

Pero además, esta novela nos va llevando hacia el último tramo de estas "Conclusiones", a algo que comentamos al principio de las mismas, así como también al principio y al final de la "Introducción" de la tesis: me refiero a la manera en que en Copi aparece la cuestión de lo "argentino", y a su imagen de autor en el medio de su obra y de su concepción del sujeto: éstas tienen un efecto sobre aquella. En efecto, su imagen de autor aparece en estado de demolición a lo largo de sus textos: en casi todas sus novelas -y en algunos cuentos- encontramos un narrador protagonista al que, en la mejor tradición de la denominada "autofabulación"94, le pasan todas las cosas imaginables, y de un modo en el cual no hay continuidad ni coherencia al pasar de un libro a otro.

\footnotetext{
${ }^{94}$ El término "autofabulación" es el que termina prefiriendo Vincent Colonna, tras hablar sobre el fenómeno literario de la "autoficción", siendo el primero el más idóneo para designar lo que él, en su tesis doctoral dirigida por Gérard Genette (adaptada para su publicación en libro en 2004), designaba como "autoficción fantástica" ("autofiction fantastique") (Colonna 2004). Según lo explica Philippe Gasparini, "autofabulation" cubre mejor el fenómeno de lo que en liteatura puede describirse como "fictionnalisation de soi', ou, pour mieux dire : projection de l'auteur dans des situations imaginaires" (Gasparini 2008: 297), ya que "autofiction", designaría solamente un procedimiento narrativo aislado (el que distingue a la autoficción fantástica), y no la totalidad de una novela: "...cette aception ne désigne pas un genre mais un procédé de narration, une figure, qui ne gouverne que rarement la totalité d'un roman" (297). Y luego, concluye Gasparini: "...il semble effectivement souhaitable de ranger les projections auctoriales dans des situations imaginaires sous la rubrique de l' 'autofabulation'” (298). Debo este señalamiento a Claudia Moronell.
} 
Copi, que, según él no era argentino, ni francés, sino "argentino de París"95, nunca dejó de revisar su cultura de origen, como ya hemos visto en el anterior capítulo de este trabajo; la cultura argentina está muy presente en toda su obra, y en ella aparecen menciones directas o alusiones que remiten tanto a su historia familiar, como a la historia política de nuestro país (que, como se sabe, tiene vinculaciones con algunos períodos de la historia de la familia de Copi). Pero aquí en esta novela no hay ninguna mención, sino que más bien lo argentino brilla por su ausencia. Los códigos culturales puestos en juego en ella, la ambientación, las bromas, remiten directamente al universo francés, para luego deshacerse de ellos en un viaje por el Mundo que anula toda idea de nación. Pero si decimos que lo argentino "brilla por su ausencia", este "brillo" es literal: la misma falta hace pensar si Copi, en esta novela, la más atípica dentro de su producción, la más alejada de lo argentino, no sugiere con su omisión algo similar a las afirmaciones de él mismo sobre su nacionalidad, y si asimismo no podría considerarse un manifiesto oculto sobre su propia idea de comunidad, así como una burla a la cultura occidental que pone a París como el centro del mundo. Daniel Link apunta un fragmento de la novela, en que la rata llamada Rakä (que es el más "viajado" de los dos amigos) le describe a Gouri "les chutes de l'Iguagu, le détroit de Magellan et le delta de l'Amazone, qui sont comme chacun sait les trois merveilles naturelles de ce monde" (Copi 1979: 15); lo que dice Link sobre este fragmento es que "[e]n la perspectiva de esa rata de París, Argentina es un intervalo geográfico comprendido entre dos de las maravillas naturales de ese mundo" (Link 2009b: 9): en ese intervalo donde Argentina no es nombrada es donde

\footnotetext{
95 "Yo siempre he sido un argentino de París. Es decir que hablo como los franceses, me visto como ellos y tengo probablemente los mismos puntos de vista respecto de las autopistas o el precio del pescado. Pero de todas maneras, no soy un francés, pertenezco a una categoría de extranjeros que los franceses consideran como tales durante dos generaciones" (entrevista con Raquel Linenberg, en Tcherkaski 1998: 113).
} 
quizá se encuentra el brillo de esa ausencia. El "argentino de París" es como la "rata de París", un animal sin patria, o mejor, cuya patria es un lugar de intervalo, de tránsito: ése es el único país al que podría pertenecer un sujeto trans.

En un fragmento de una novela que hemos comentado brevemente, y donde sí se aborda el tema argentino, L'internationale argentine, el narrador y protagonista (llamado Copi), habla de su esposa diciendo que se la imagina actuando en un papel que, según él, toda mujer argentina habría soñado con encarnar, el de Eva Perón (Copi 1988: 43), es decir, ese símbolo nacional for export al que Copi le dedicó su primera gran obra teatral. En otro momento de la misma novela, "Copi" describe a su mujer diciendo que lleva un peinado con el cabello bien estirado hacia atrás sobre la cabeza, "un peu comme Eva Peron" (87). Ser "como Eva Perón" es ser "como una mujer argentina". Como hemos visto antes, en el universo de Copi, vestirse de Eva Perón es "encarnar" o "ser" Eva Perón, así como vestirse de mujer es "ser" una mujer; o vestirse de "mujer argentina" es "ser" una mujer argentina. Esa conjunción entre "vestido", "rol"/"papel", "género", "cuerpo" y "sujeto" es lo que Copi problematizó a lo largo de toda su obra. La identidad de autor argentino, como la de cualquier mujer, o la de cualquier hombre fue, para Copi, no más que una identidad trans, porque siempre que la tomó o la ocupó, no pudo, al mismo tiempo, dejar de considerarla como lo que realmente era: un rol teatral. 


\section{BIBLIOGRAFÍA}

\section{De Copi:}

Copi (1979). La cité des rats, París, Pierre Belfond.

Copi (1982). La guerre des pédés, París, Albin Michel.

Copi (1983). Virginia Woolf a encore frappé, París, Persona.

Copi (1986a). Théâtre. Tome I, París, Christian Bourgois.

Copi (1986b). Théâtre. Tome II, París, Christian Bourgois.

Copi (1988). L'internationale argentine, París, Pierre Belfond.

Copi (1999) [1977]. Le bal des folles, París, Christian Bourgois.

Copi (2000). Eva Perón, Buenos Aires, Adriana Hidalgo [Traducción de Jorge Monteleone].

Copi (2002). Cachafaz / La sombra de Wenceslao, Buenos Aires, Adriana Hidalgo.

\section{Sobre Copi:}

Aguirre, Osvaldo (2004). "El sentido del hablar". Bazar Americano.com. El sitio de Punto de Vista online, noviembre. Disponible online: http://www.bazaramericano.com/resenas/articulos/copi_aguirre.htm>

Aira, César (1991). Copi, Rosario, Beatriz Viterbo.

Amícola, José (2000). Camp y posvanguardia. Manifestaciones culturales de un siglo fenecido, Buenos Aires, Paidós.

Amícola, José (2008). “Autoficción, una polémica literaria vista desde los márgenes (Borges, Gombrowicz, Copi, Aira)". Olivar. Revista de Literatura y de Cultura Española, año 9, número 12, 181-197. 
Avanzo, Sandro (2008). "Raúl che ama la mamma, in arte Copi". En: Stefano Casi (comp.), Il teatro inopportuno di Copi, Pisa, Titivillus, 192-199.

Barbéris, Isabelle (2006). "Copi: le travestissement entre parodie et vanité". En: Catherine Dousteyssier-Khoze y Floriane Place-Verghnes (ed.), Poétiques de la parodie et du pastiche de 1850 à nos jours, Nueva York, Peter Lang, 215-226.

Barbéris, Isabelle (2008). "Lo sketch, unità elementare del teatro di Copi 1964-1968". En: Stefano Casi (comp.), Il teatro inopportuno di Copi, Pisa, Titivillus, 69-81.

Barbéris, Isabelle (2014). Les mondes de Copi. Machines folles et chimères, París, Orizons.

Bruera, Matías (2011). "El ser animal. Homínidos, humanismo y posthumanismo". Pensamiento de los Confines, número 27 , verano otoño 2011, 81-96.

Bauer, Jerry (2008). "Conversazione sensa complessi con un grande artista della provocazione". En: Stefano Casi (comp.), Il teatro inopportuno di Copi, Pisa, Titivillus, 179-191.

Casi, Stefano (2008). "Torri, piramidi e altri rifugi nel teatro de Copi”. En: Stefano Casi (comp.), Il teatro inopportuno di Copi, Pisa, Titivillus, 4761.

Casi, Stefano (2012). "Drammaturgia del fumetto: Copi a strisce e senza". En: Alberto Manco (dir.). Comunicazione e Ambiente. Orientare le Risorce, Aiutare a capire, Stimolare ad agire, Inspirare il cambiamento, Napoli, Università degli studi di Napoli, 2012, 119-124.

Ceccaty, René de (2007). "Copi et la fiction du néant". Alternatives théâtrales 92, 16-18. 
Corvin, Michel (1991). “Copi”. En: Corvin, Michel (ed.), Dictionnaire encyclopédique du théâtre, París, Bordas, 205-206.

Delgado, Verónica (1996). "Las poéticas antirrepresentativas en la narrativa argentina de las últimas dos décadas: César Aira, Alberto Laiseca, Copi, Daniel Guebel". Celehis. Revista del Centro de Letras Hispanoamericanas de la Universidad de Mar del Plata, 5: 255-268.

Di Fonzo Bo, Marcial (2017). "Copi en argentino. Extractos de una conversación con Marcial Di Fonzo Bo". En: Marcial Di Fonzo Bo [et. al.], Fabián Díaz, Ariel Farace, Andrés Gallina, Carlos Gamerro y Alejandro Tantanian (eds.), TC-TNA n ${ }^{\circ}$, Copi vive, Teatro Nacional Cervantes, 5-11.

Fontana, Juan Carlos (2003). "Copi frente a una sociedad que se devora a sí misma". Picadero. Publicación bimestral del Instituto Nacional del Teatro, Enero/Febrero 2003, 10-11.

Gasparini, Pablo (2010). "La lección do Néstor". Caracol, No 1, Dossiê Traduçao, 86-109.

Gasparini, Pablo (2006). "Patria y 'filiatrías': exilio y transnacionalidad en Gombrowicz, Copi y Perlongher". Hispamérica: Revista de Literatura, número 105, 45-48.

Gonzalez Doreste, Dulce María (1994). “El teatro francés contemporáneo: Copi". Juan Bravo Castillo (ed.), Actas del II coloquio sobre los estudios de filología francesa en la universidad española, Universidad de Castilla-La Mancha ed., 383-387.

Link, Daniel (2005). Clases: literatura y disidencia, Buenos Aires, Norma.

Link, Daniel (2009a). Fantasmas. Imaginación y sociedad, Buenos Aires, Eterna Cadencia.

Link, Daniel (2009b). "La cruzada de las ratas". Ñ Revista de Cultura, Buenos Aires, 12 de diciembre de 2009, 9. 
Logie, Ilse (2005). "La desmitificación de la Argentina en Cachafaz de Copi". Nuevas cartografías críticas: problemas actuales de la Literatura Iberoamericana. Actas del $1^{\circ}$ Congreso Regional del Instituto Internacional de Literatura Iberoamericana. Disponible online: http://www.geocities.ws/aularama/actas.htm

Lozano, Ezequiel (2013). "Performatividad de Género y Travestismo a través de Escenificaciones de Las Criadas de Genet". Revista Brasileira de Estudos da Presença, vol. 3, número 3, setiembre/diciembre de 2013, 805-818. Disponible online: http://www.seer.ufrgs.br/presenca.

Lozano, Ezequiel (2015). Sexualidades disidentes en el teatro: Buenos Aires, años 60, Buenos Aires, Biblos.

Luppi, Juan Pablo (2015). "El escritor uruguayo y la imaginación. Una tragedia bárbara de Copi en argentino". Catedral Tomada. Revista de Crítica Literaria Latinoamericana, Vol. 3, № 5, octubre de 2015. Disponible online: http://catedraltomada.pitt.edu

Moneta Carignano, María Laura (2011). Avatares da literatura latinoamericana contemporânea: neobarroco e paródia, tesis para la obtención del grado de Doctora en Letras de la Universidad Estadual Paulista Júlio de Mesquita Filho, Brasil.

Montaldo, Graciela (1990). "Un argumento contraborgiano en la literatura argentina de los años '80 (Sobre C. Aira, A. Laiseca y Copi)". Hispamérica. Revista de Literatura, XIX, 55, 105-112.

Monteleone, Jorge (2000). “Nota sobre la traducción”. En: Copi [Raúl Damonte Botana], Eva Perón, Buenos Aires, Adriana Hidalgo, 14 [Traducción de Jorge Monteleone].

Monteleone, Jorge (2012). "Copi: peripecias de un clásico alternativo". La Nación, suplemento adn Cultura, 30 de noviembre de 2012. 
Montes, Alicia (2010). "Camp neobarroco: homenaje, artificio y violencia". Confluenze. Revista di Studi Iberoamericani, Dipartimento di Lingue e Letterature Straniere Moderne Università di Bologna, Vol. 1, № 2, 99-111.

Muslip, Eduardo (2007). La producción narrativa, dramática y gráfica de Copi: las metamorfosis de la identidad, tesis para la obtención del grado de Doctor presentada en Arizona State University, Estados Unidos, diciembre de 2007 (mimeo.).

Muslip, Eduardo (2009a). "Prólogo". En: Copi, La ciudad de las ratas, traducción de Guadalupe Marando, Eduardo Muslip y María Silva, Buenos Aires, El Cuenco de Plata, 5-13.

Muslip, Eduardo (2009b). "El lento regreso de Copi. Cómo mirar todo desde abajo". Perfil, Año V, 13 de diciembre de 2009, Buenos Aires.

Disponible online: http://www.diarioperfil.com.ar/edimp/0426

Negroni, María (2017). “El domicilio del destierro”. En: Marcial Di Fonzo Bo [et. al.], Fabián Díaz, Ariel Farace, Andrés Gallina, Carlos Gamerro y Alejandro Tantanian (eds.), TC-TNA $n^{\circ} 2$, Copi vive, Teatro Nacional Cervantes, 55-64.

Neveux, Olivier (2006). "Rire comme une folle... Sur d'eventuels sffets politiques de la parodie. La Tour de la Défense de Copi”. Recherches \& Travaux $69 . \quad$ Disponible online: www.recherchestravaux.revues.org/index304.html

Obregón, Ezequiel (2013). "Prólogo". En: Ezequiel Obregón (comp.), Teatro queer, Buenos Aires, Colihue, 5-13.

Pimentel Teixeira, Renata (2007). Copi: transgressão e escrita transformista, tesis para la obtención del grado de Doctora en Letras de la Universidade de Pernambuco, Brasil. Disponible online: https://repositorio.ufpe.br/handle/123456789/7537 
Podlubne, Judith y Alberto Giordano (2000). "Exilio y extraterritorialidad: Juan Rodolfo Wilcock y Héctor Bianciotti”. En: Elsa Drucaroff (dir. del volumen, Noé Jitrik dir. general), Historia crítica de la literatura argentina, Vol. 11, Buenos Aires, Emecé, 381-403.

Pol, Joanne (2010). Queering Latin American Theater: A Panoramic Study And Its Performative Implications, tesis para la obtención del grado de Doctor por la University of Miami, Estados Unidos. Disponible online: https://scholarship.miami.edu/esploro/outputs/doctoral/

Pron, Patricio (2007). "Aquí me río de las modas". Procedimientos transgresivos en la narrativa de Copi y su importancia para la constitución de una nueva poética en la literatura argentina, tesis para la obtención del grado de doctor en la Philosophischen Fakultät de la Georg-August-Universität de Göttingen, Alemania. Disponible online: file:///C:/Users/user/Downloads/pron.pdf

Pustianaz, Marco (2008). "Il soggetto 'fuore di sé'. Ovvero, il godimento di essere isteriche". En: Stefano Casi (comp.). II teatro innoportuno di Copi, Pisa, Titivillus, 34-46.

Rees Roberts, Nick (2005). “Copi (Raoul Damonte) (1939-1987)”. En: Bill Marshall (ed.), France and The Americas. Culture, Politics, and History. A Multidisciplinary Encyclopedia, volumen 1, 299-300.

Rosenzvaig, Marcos (2003). Copi: sexo y teatralidad, Buenos Aires, Biblos.

Salas, Hugo (2017). "La aventura de las copias de Eva". En: Marcial Di Fonzo Bo [et. al.], Fabián Díaz, Ariel Farace, Andrés Gallina, Carlos Gamerro y Alejandro Tantanian (eds.), TC-TNA $\mathrm{n}^{\circ} 2$, Copi vive, Teatro Nacional Cervantes, 13-27.

Sarlo, Beatriz (2003). La pasión y la excepción, Buenos Aires, Siglo XXI. 
Tambascio, Gustavo (1997). "Una herencia inoportuna. El teatro de Copi, a diez años de su muerte". Cuadernos Hispanoamericanos 563 (1997), 107-112.

Tcherkaski, José (1998). Habla Copi. Homosexualidad y creación, Buenos Aires, Galerna.

Thomaz, Paulo César (2010). "O travestismo como artificio: simulaçao, metamorfose e representaçao em La guerra de los putos, de Copi”. Anais da II Jornada de Gênero e Literatura 2010: http://www.gelbc.com.br/anais_jornada_genero.html

Vázquez, Karina (2009) "Eva vive en otra parte: cambio de signo e identidad en Eva Perón de Copi". Delaware Review of Latin American Studies, vol. 10, número 10, 30 de diciembre, 2009. Disponible online: http://www.udel.edu/LAS/Vol10-2Vazquez.html

Vázquez, Laura (2009). "Después del fin del arte: Copi”. Boletín de Estética, año $\mathrm{V}$, número 10, 39-63.

Weiss, Jason (2003). The Lights of Home. A Century of Latin American Writers in Paris, Nueva York, Routledge.

Wetsel, David (1994). "Copi”. En: David W. Foster, Latin American Writers on Gay and Lesbian Themes: a Bio-Critical Sourcebook, Westport, Greenwood Press, 116-121.

\section{General:}

Arnés, Laura (2014). "De Lauretis básico”. Página/12. Suplemento Soy, 25 de abril.

Balza, Isabel (2009). "Bioética de los cuerpos sexuados: transexualidad, intersexualidad y transgenerismo". Isegoría. Revista de Filosofía Moral y Política, № 40, enero-junio 2009, 245-258. 
Barthes, Roland (2003) [1964]. Ensayos críticos, Buenos Aires, Seix Barral. [Traducción de Carlos Pujol]

Bellucci, Mabel y Rapisardi, Flavio (2001). "Identidad: diversidad y desigualdad en las luchas políticas del presente". En: VV. AA., Teoría y filosofía política. La recuperación de los clásicos en el debate latinoamericano, Buenos Aires, CLACSO, Consejo Latinoamericano de Ciencias Sociales, 193-207.

Braidotti, Rosi (2005). Metamorfosis. Hacia una teoría materialista del devenir, Madrid, Akal. [Traducción de Ana Varela Mateos]

Brustein, Robert (1970). De Ibsen a Genet: la rebelión en el teatro. Buenos

Aires, Troquel. [Traducción de Jorge L. García Venturini]

Butler, Judith (2002) [1993]. Cuerpos que importan. Sobre los límites materiales y discursivos del "sexo", Buenos Aires, Paidós.

Butler, Judith (2007) [1990]. El género en disputa. El feminismo y la subversión de la identidad, Barcelona, Paidós. [Traducción de María Antonia Muñoz].

Brum, José Luis (2010). "El cuerpo en el transexual”. Revista Uruguaya de Psicoanálisis, 111, 125-126.

Cabral, Mauro (2007). “Transgénero”. En: Susana Beatriz Gamba (coord.), Diccionario de Estudios de Género y Feminismos, Buenos Aires, Biblos, 325-327.

Castellanos, Gabriela (2006). Sexo, género y feminismo: tres categorías en pugna, Cali, Universidad del Valle.

Colonna, Vincent (2004). Autofiction \& Autres Mythomanies littéraires, Auch, Tristram.

Cornago, Óscar (2006). "La teatralidad como crítica de la modernidad". Tropelías. Revista de Teoría de la Literatura y Literatura Comparada, Zaragoza, 15-17, 242-265. 
Crouzeilles, Carmen (2006). "Pánico y después: escándalo, revuelta y espectáculo". En: Claudia Kozak (comp.), Deslindes. Ensayos sobre la literatura y sus límites en el siglo XX, Rosario, Beatriz Viterbo, 119-138.

De Santo, Magdalena (2015). "Modos de construir género: de la performance a la performatividad". En: Pamela Abellón y Magdalena De Santo, Dos lecturas sobre el pensamiento de Judith Butler, Villa María, Eduvim, 137-247.

Ekins, Richard y Dave King (2006). The Transgender Phenomenon, Londres, SAGE Publications.

Eribon, Didier (1999). Réflexions sur la question gay, París, Fayard.

Eribon, Didier (2004). Una moral de lo minoritario. Variaciones sobre un tema de Jean Genet. Barcelona, Anagrama [Traducción de Jaime Zulaika].

Espinosa-Miñoso, Yuderkys (2007). "Heterosexualidad obligatoria". En: Susana Beatriz Gamba (coord.), Diccionario de Estudios de Género y Feminismos, Buenos Aires, Biblos, 168-171.

Esslin, Martin (1966). El teatro del absurdo. Barcelona, Seix Barral. [Traducción de Manuel Herrero]

Feldman, Lada Čale (2000). "Performative Cross-Genderings And Disciplinary Border-Crossings". Narodna umjetnost - Hrvatski časopis za etnologiju i folkloristiku, $\mathrm{n}^{\circ} 37,7-20$.

Femenías, María Luisa (2012). Sobre sujeto y género: re-lecturas feministas desde Beauvoir a Butler, Rosario, Prohistoria.

Féral, Josette (2002). "Theatricality: The Specificity of Theatrical Language”. SubStance, Vol. 1, n 2/3, 94-98.

Fernández, Claudia (2010). "La tiranía del disfraz: algunas consideraciones en torno al papel de la vestimenta en la Comedia Griega Antigua”. 
Synthesis, 17, 81-97. Disponible en:

http://www.memoria.fahce.unlp.edu.ar/art revistas/pr.4219/pr.4219.pdf

Fernández, Josefina (2004). Cuerpos desobedientes: travestismo e identidad de género, Buenos Aires, Edhasa.

Fernández, Josefina (2007a). "Transexualidad”. En: Susana Beatriz Gamba (coord.), Diccionario de Estudios de Género y Feminismos, Buenos Aires, Biblos, 322-324.

Fernández, Josefina (2007b). "Travestismo". En: Susana Beatriz Gamba (coord.), Diccionario de Estudios de Género y Feminismos, Buenos Aires, Biblos, 330-332.

Floeck, Wilfried (1994). “¿Del teatro de dirección al teatro de texto? Tendencias y problemas del teatro francés". Teatro: Revista de Estudios Teatrales, número 5, 1994, 141-157.

Fontenla, Marta Amanda (2007). "Patriarcado". En: Susana Beatriz Gamba (coord.), Diccionario de Estudios de Género y Feminismos, Buenos Aires, Biblos, 256-258.

Fridman, Irene (2007). "Identidad de género". En: Susana Beatriz Gamba (coord.), Diccionario de Estudios de Género y Feminismos, Buenos Aires, Biblos, 175-176.

Garber, Marjorie (1992). Vested Interests. Cross-Dressing \& Cultural Anxiety, Nueva York-Londres, Routledge.

Gasparini, Philippe (2008). Autofiction. Une aventure du langage. París, Éditions du Seuil.

Genet, Jean (1963). Les bonnes \& Comment jouer Les Bonnes. Lyon, Marc Barbezat.

Genet, Jean (1986). Notre-Dame-des-Fleurs. Saint-Amand, Gallimard. 
Glocer Fiorini, Leticia (2010). "Sexualidades nómades y transgénero: un desafío a la polaridad masculino/femenino". En: Zelcer, Beatriz (comp.), Diversidad sexual, Buenos Aires, APA Editorial, 57-76.

Gramuglio, María Teresa (1992). “La construcción de la imagen”. En: Héctor

Tizón y Rodolfo Rabanal, La escritura argentina, Argentina, Universidad Nacional del Litoral/Ediciones de la Cortada, 35-64.

Helbo, André (2012) [2007]. El teatro: ¿texto o espectáculo vivo?, Buenos Aires, Galerna [Traducción de Susana Cáceres].

Kattenbelt, Chiel (2008). "Intermediality in Theatre and Performance: Definitions, Perceptions and Media Relationships". Cultura, lenguaje y representación. Revista de Estudios Culturales de la Universitat Jaume I, volumen 6, Mayo de 2008 (título del número: "La intermedialidad"), 19-29.

Laplanche, Jean y Pontalis, Jean-Bertrand (2007) [1967]. Diccionario de psicoanálisis, Buenos Aires, Paidós [Traducción de Fernando Gimeno Cervantes].

López, Rodrigo (2018). "Mayo francés: de las barricadas a la revolución sexual". Ideas de Izquierda. Revista de Política y Cultura, Número 42, Abril-mayo, 26-28.

López Penedo, Susana (2008). El laberinto queer. La identidad en tiempos del neoliberalismo, Barcelona, Egales.

Loyden Sosa, Humbelina y Sánchez Bringas, Ángeles (2007). “Cuerpo”. En: Susana Beatriz Gamba (coord.), Diccionario de Estudios de Género y Feminismos, Buenos Aires, Biblos, 74-76.

Lozano, Ezequiel (2013). "Performatividad de Género y Travestismo a través de Escenificaciones de Las Criadas de Genet". Revista Brasileira de Estudos da Presença, vol. 3, número 3, 
setiembre/diciembre de 2013, 805-818. Disponible online: http://www.seer.ufrgs.br/presenca.

Mas Grau, Jordi (2015). "Transexualidad y transgenerismo. Una aproximación teórica y etnográfica a dos paradigmas enfrentados". Revista de Dialectología y Tradiciones Populares, vol. LXX, $\mathrm{n}^{\circ} 2$, juliodiciembre 2015, 485-501.

Moronell, Claudia (2015). Héctor Bianciotti en lengua francesa: 'la imposible restitución del pasado'. Tesis para la obtención del grado de Doctora en Letras en la Universidad Nacional de La Plata, Argentina, Disponible online: www.memoria.fahce.unlp.edu.ar/tesis/te.1173/te.1173.pdf

Olivares Pardo, María Amparo (1995). “Aproximación a algunos fenómenos de la traducción teatral: Les Bonnes de J. Genet" en LAFARGA MADUELL, Francisco y Dengler Gassin, Robert (coords.), Teatro y traducción, Barcelona, Universitat Pompeu Fabra, 239-250.

Páez, Alicia (1967). "El concepto de happening y las teorías". En: Oscar Masotta (et. al), Happenings, Buenos Aires, Jorge Álvarez, 17-47.

Pavis, Patrice (2008) [1996]. Diccionario del teatro. Dramaturgia, estética, semiología, Buenos Aires, Paidós [Traducción de Jaume Melendres].

Pelletieri, Osvaldo (ed.) (1993). De Sarah Bernhardt a Lavelli. Teatro francés y teatro argentino 1890-1990, Buenos Aires, Galerna.

Preciado, Beatriz (2009). "Terror anal: apuntes sobre los primeros días de la revolución sexual" (epílogo). En: Guy Hocquenghem, El deseo homosexual, Barcelona, Melusina, 135-174.

Preciado, Beatriz (2011) [2000]. Manifiesto contrasexual, Barcelona, Anagrama. [Traducción de J. Díaz y C. Meloni] 
Rubino, Atilio (2019). "Hacia una (in)definición de la disidencia sexual. Una propuesta para su análisis en la cultura". Revista LUTHOR, número 39, Vol. IX, Febrero, 62-80.

Sanchis Sinisterra, José (1991). "El espacio dramático”. Pausa. Quadern de teatri contemporani, $\mathrm{n}^{\circ}$ 8, Barcelona, Institut del Teatre. Disponible online: http://www.revistapausa.cat/el-espacio-dramatico/

Sayre, Henry (1995). "Performance". En: Frank Lentricchia y Thomas McLaughlin, Critical Terms for Literary Studies, Chicago, University of Chicago, 91-104.

Senelick, Laurence (1990). "Transvestism, Theatrical”. En: Wayne R. Dynes (ed.), Encyclopedia of Homosexuality, Nueva York, Routledge, vol. 2, 1314-1323.

Senelick, Laurence (2000). The Changing Room: Varieties of Theatrical Cross-Dressing, Nueva York, Routledge.

Sibalis, Michael (2005). "Gay Liberation Comes to France: The Front Homosexuel d'Action Révolutionnaire (FHAR)". En: Ian Coller, Helen Davies and Julie Kalman (eds), French History and Civilization: Papers from the George Rudé Seminar, vol. 1, Melbourne, The George Rudé Society, 267-78.

Sontag, Susan (1996) [1961]. "Notas sobre lo camp". En: Contra la interpretación, Buenos Aires, Alfaguara, 355-376. [Traducción de Horacio Vázquez Rial]

Taylor, Diana (1993). "Negotiating Performance". Latin American Theatre Review, Vol. 26, № 2, Primavera 1993, 49-57.

Tcherkaski, José (1983). El teatro de Jorge Lavelli. El discurso del gesto, Buenos Aires, Universidad de Belgrano.

Torres Monreal, Francisco (1986). "Introducción". En: Fernando Arrabal, Teatro pánico, ed. Francisco Torres Monreal, Madrid, Cátedra, 9-84. 
Trastoy, Beatriz y Perla Zayas de Lima (2006). Lenguajes escénicos, Buenos Aires, Prometeo.

Trastoy, Beatriz (2009). "Una renovación fallida: Armando Discépolo y el grotesco criollo". En: C. Manzoni (dir.) Historia crítica de la literatura argentina, tomo 7, Buenos Aires, Emecé, 201-215.

Ubersfeld, Anne (1989). Semiótica teatral, Madrid, Cátedra [Traducción y adaptación de Francisco Torres Monreal].

Vandersickel, Karen (2010-2011). Le travestissement ou la suspension de l'identité. Le problème de l'identité de genre dans Notre-Dame-desFleurs de Jean Genet, tesis para la obtención del grado de Magister, Universiteit Gent, Bélgica. Disponible online: https://libstore.ugent.be/fulltxt/RUG01/001/786/645/RUG01001786645_2012_0001_AC.pdf

Viñas, David (1996) [1964]. Literatura argentina y realidad política II. De Lugones a Walsh, Buenos Aires, Sudamericana.

Viñas, David (1997) [1973]. Grotesco, inmigración y fracaso: Armando Discépolo. Buenos Aires, Corregidor. 